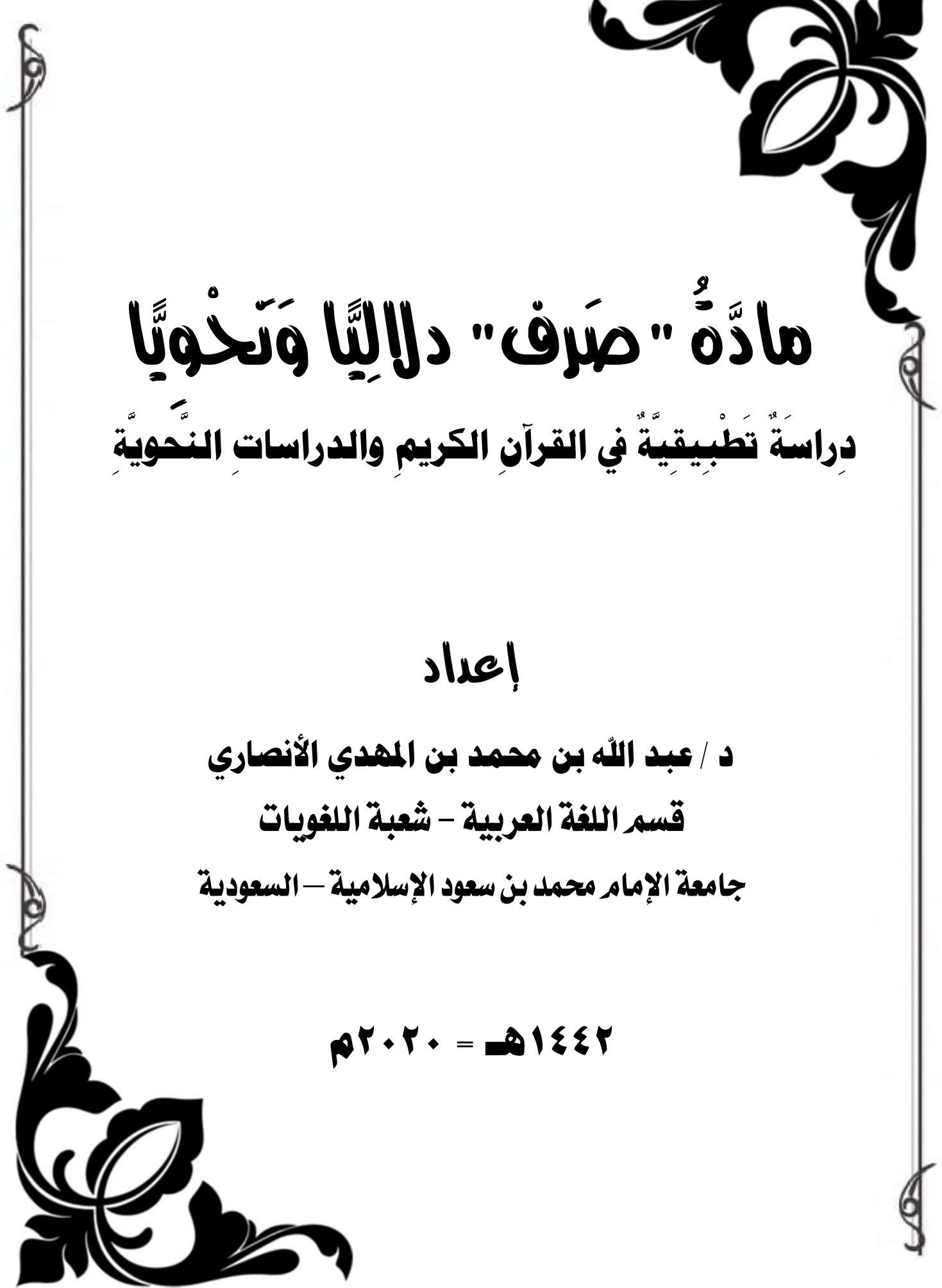



مجلة كلية اللغة العربية بالمنوفية العدد الخامس والثلاثون - إصدار ديسمبر 2020م C 20
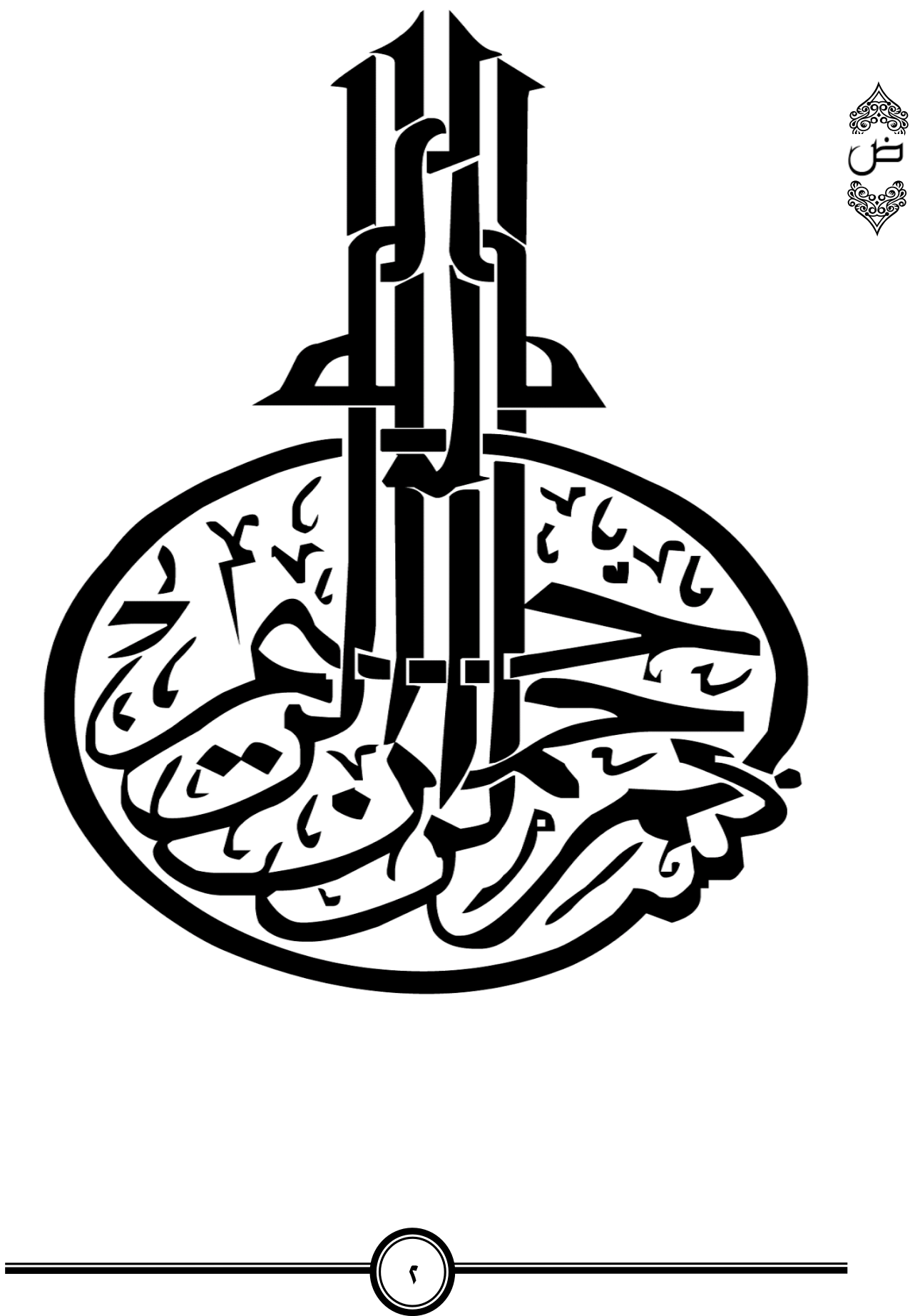



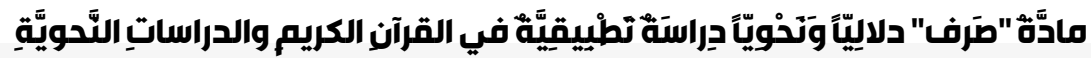

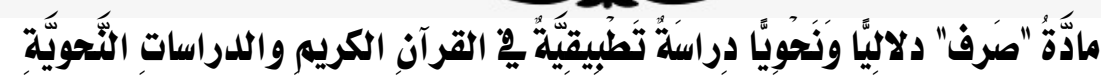

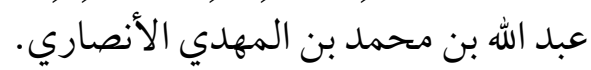

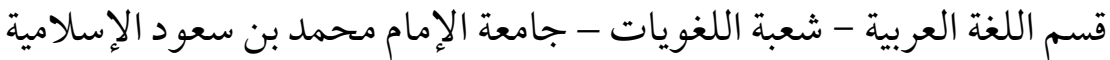

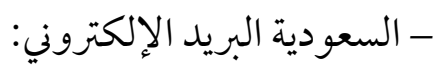

amalansare@imamu.edu.sa

موضوع الدراسة كلمة"صرف" اللغوية، من حيث هي مشتركك لفظيُّ ثريّ

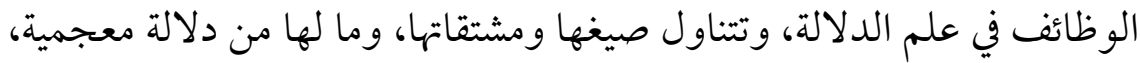

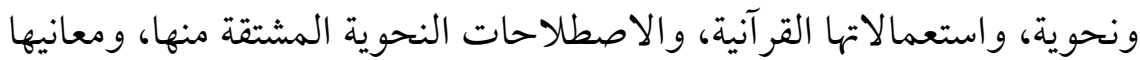

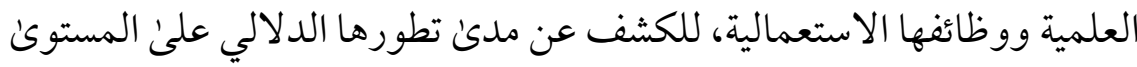

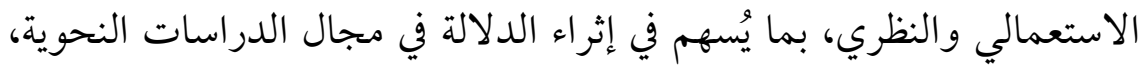

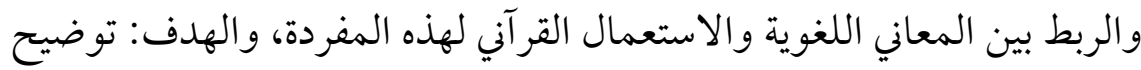
قيمة المصطلحات النحوية المشتقة من هذه المادة، وإزاحة الفهم الخاطئ في قصر هذه المصطلحات على جانب "علم الصرف" دون النحو، واستبانة أثر هُه

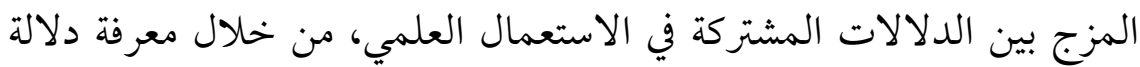
اللفظ الجذرية في تحديد إطلاقاته في الدراسات اللغوية العلمية والمصطلحية، الدئه ويتكون البحث من مقدمة محتوية لطبيعة موضوعه، وخطته وعناصره، ثم بيان

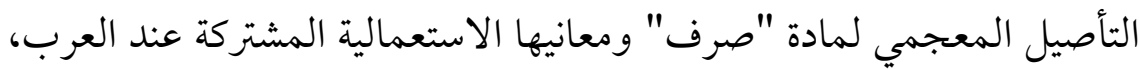
ثم إحصاء لمشتقاتها الواردة في القرآن الكريم، ثم مصطلحماتها فئها في الدراسات

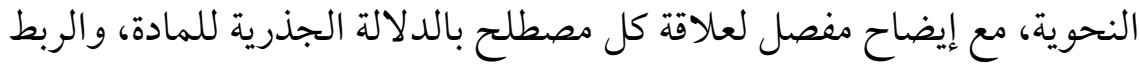

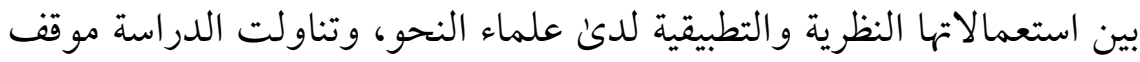

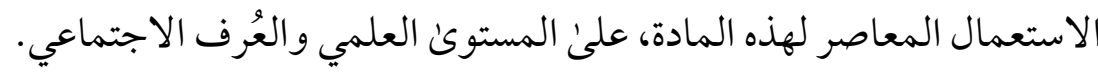
الكلمات المفتاحية:مادة- صرف- نحويا- دراسة- دراسات- تطبيقية- 

An applied study in the Noble Qur'an and

\section{grammatical studies}

By/ Abdullah Ibn Mohammed Ibn El-Mahdy El-Ansary, Arabic Department, Linguistics, Imam Mohammed Ibn Saud Islamic University, Kingdom of Saudi Arabia.

E-mail;- amalansare@imamu.edu.sa

\section{Abstract:}

The subject of the study is the linguistic word "morphology". It is a common phonetic with rich functions in semantics. It deals with formulas and derivatives, its lexical and grammatical significance, its Qur'anic uses, the grammatical conventions derived from it, its scientific meanings and its use functions, to reveal the extent of its semantic development at the use and theoretical level, in a way that contributes to enriching the connotation in the field of grammatical studies, and linking between linguistic meanings and the Qur'anic use of this term. The objective is to clarify the value of the grammatical terms derived from this subject, to eliminate the misconception in limiting these terms to the aspect "morphology" without grammar, and to identify the effect of mixing between common connotations in scientific usage, by knowing the meaning of the word's root in determining its releases in scientific and terminological linguistic studies. The research consists of an introduction containing the nature of its topic, its plan and its elements and then an explanation of the lexical foundation of "morphology" and its common usage meanings among Arabs, then a census of its derivatives contained in the Holy Qur'an, then its terminology in grammatical studies with a detailed explanation of the relationship of each term with the radical connotation of the subject and the link between its theoretical and applied uses to the grammarians. The study deals with the position of contemporary use of this subject on the scientific level and social norm.

Keywords:- Subject - morphology - grammatically study - applied studies - Qur'an. 



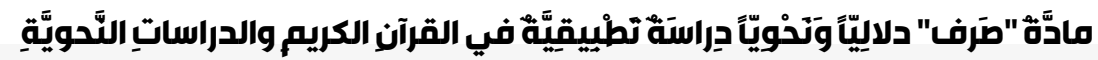

\begin{tabular}{|c|c|c|}
\hline \multicolumn{3}{|c|}{ أهول البمث وتفريعاته } \\
\hline r..مشكلة البحث & ץ. مجال الدراسة & الدراسة. \\
\hline 7. هدف البحث ومصادره & ه أهمية البحث. & ع -فروض البحث. \\
\hline 9 . هيكل البحث. & 1. أسئلة البحث. & Vنهج البحث. V. V \\
\hline & & • • - الدراسات السابقة. \\
\hline
\end{tabular}

\section{مكمنات الدراسة}

$$
\text { أولا: التأصيل المججمي، وفيه: }
$$

r. التوسع في دلالتها، واستعمالاتها المجازية، قديمًا وحديثا.

$$
\text { ثانيا : مأخذ التصريف من "الاشتقاق" }
$$

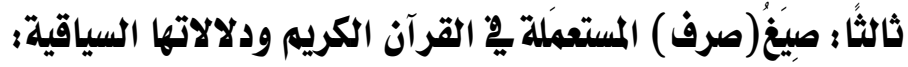

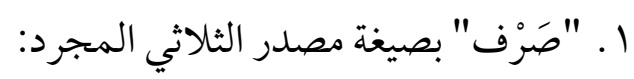

r. "صَرَفَ" المخخفَّفَ، ماضيه ومضارعه و أمْره، مجرَّدًا ومزيدًا:

$$
\begin{aligned}
& \text { r. "صَرَّف" المضعَّف، بصيغَتَي الماضي والمضارع: } \\
& \text { ع. صيغة المصدر من الرباعي بالتضعيف "تصريف" } \\
& 0
\end{aligned}
$$

7 . صيغة "مَفْعِل " الدالة على المكان

$$
\text { رابعًا: مادة "صرف" مِِ الدراسات النحوية }
$$

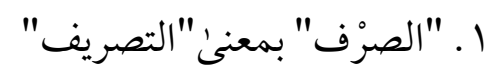

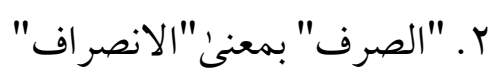




\section{مجلة كلية اللغة العربية بالمنوفية العدد الخامس والثلاثون - إصدار ديسمبر 2020م}

ore

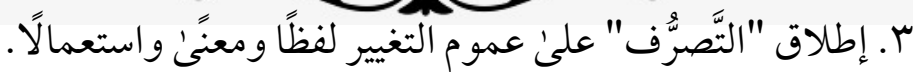

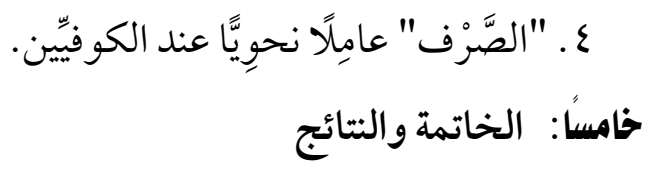

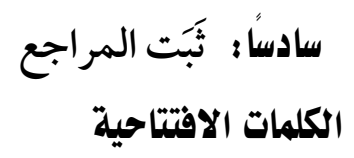

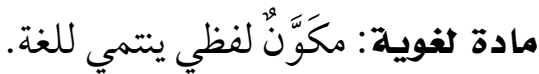

الدلالة : ما تحيل إليه الكلمة من المفاهيم الخارجية والضمنية.

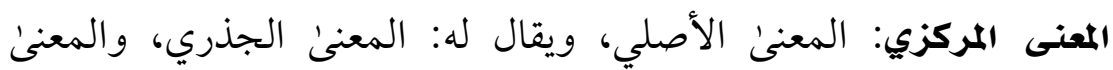

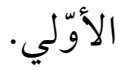

الدراسات النحوية: المعالجات التي تتناول "النحو" بالمفهوم الشامل،

$$
\text { وتشمل : الصوت، والصرف، والتركيب، والدلالة. }
$$

الدراسات القرآنية : المعالجات العلمية؛ النظرية والتطبيقية؛ التي ميدانها

$$
\text { القرآن الكريم، لفظًا ودلالةً وتركيبًا. }
$$

دلالة "صرف" : المعاني التي تَرِد كلمة "صرف" دالَّلَّة عليها لغةً واصطلاحًا أو

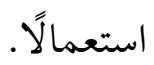

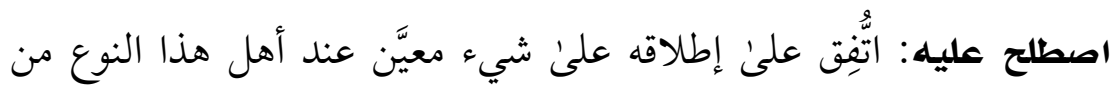

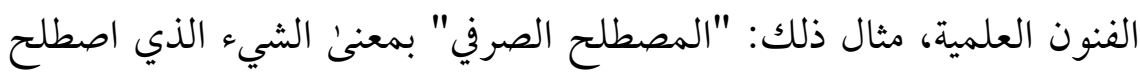
عليه علماء الصرف، و"المصطلح النحوي" بمعنئ الشيء الذي اصطلح عليه

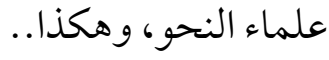




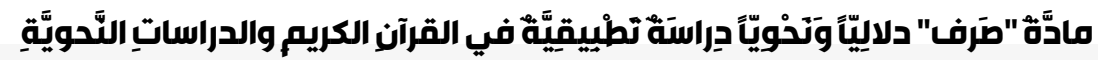

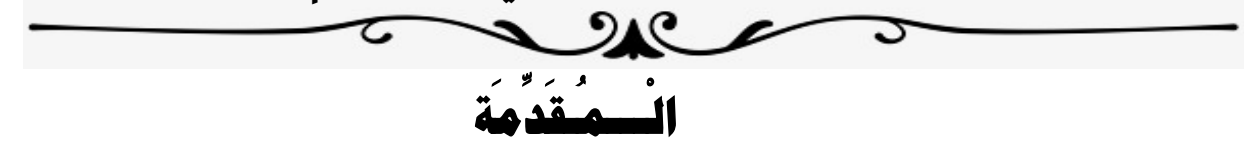

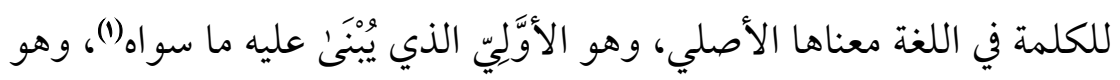

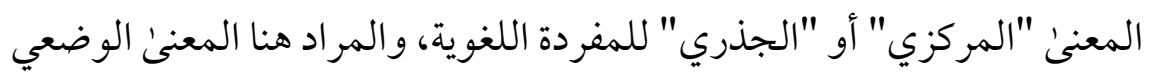

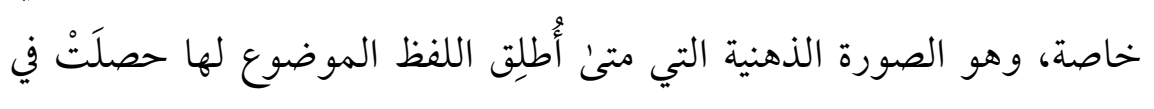
العقل مرتبطة بذلك اللفظ(r)

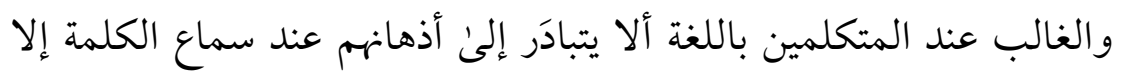

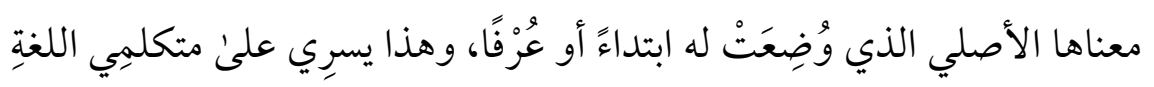

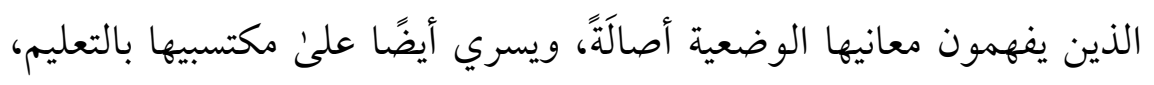

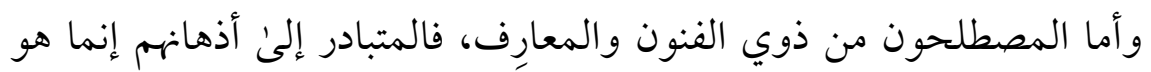

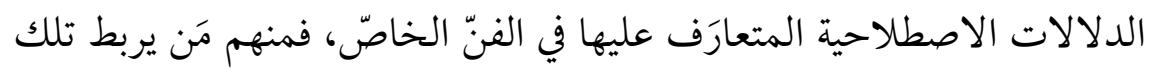

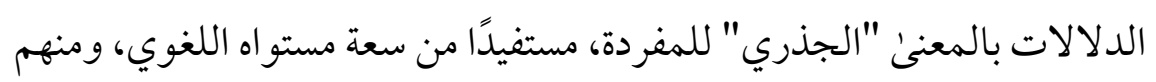
من لا يتجاوز الدلالة العلمية التي عُرِفتْ بها الكلمة في فنّه.

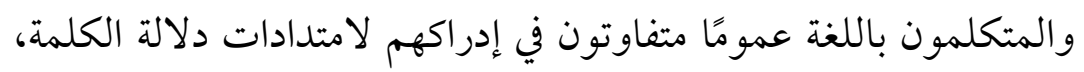

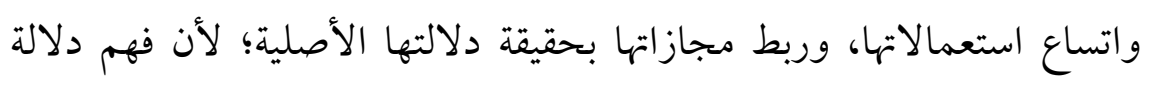

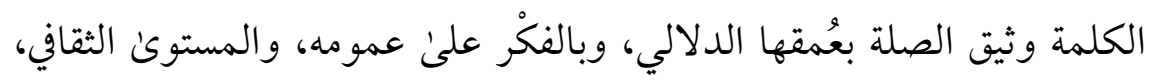
والمحيط الاجتماعي على جميع مستوياته، وهي في كل ذلك تمثل في إطارها

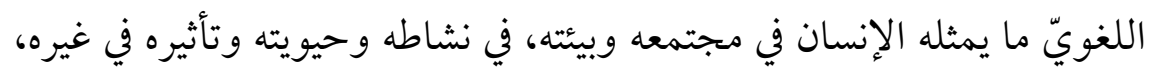
وتأثره بمحيطه.

$$
\begin{aligned}
& \text { 1) انظر لتعريف "الأصل" الحدود للرماني صدسV }
\end{aligned}
$$

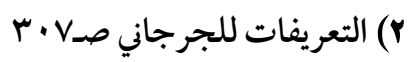


والكلمة وحدة دلالية ذات أهمية كبرىن في الدراسات اللغوية، تمثل قمة

أدوات "علم الدلالة"(() وهو علم مخصص لدراسة المعنى، على مستوىن

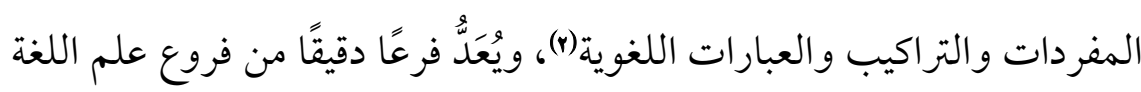
العام(r)، وتُعََّف الدلالة بأنها " كونُ الشيء بحالة يلزم من العلم به العلمُ بشيء

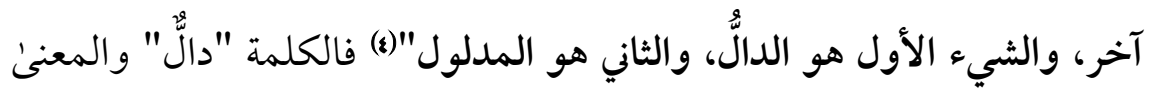
الذي تُحيل إليه "مدلول عليه" وهذه الحالة الملزمة للعلم بالمدلول (المشار إليه في الخارج) هي المفهوم الأصلي للكلمة، حسب العُرْف التواصلي بين المتكلمين باللغة، إذ لاتكتسب المفردة مكانتها الدلالية إلا في سياقاتها التواصلية بين مستخدميها(ه). إذن تتحدد القيمة المعجمية للكلمة في اللغة بوظائفها الدلالية، وهي الصور الذهنية، والمقاصد النفسية التي تشير إليها ابتداءً(1)، ولا سيما وظائفها المتعلقة بطبيعتها اللفظية والمعنوية، فهي التي تُكسبُها المرونة و القدرة على التعبير عن المقاصد والأغراض المتعددة، والأساليب المختلفة، في المجالات العلمية والأدبية والدينية، وإلىن مثل هذا يمكن أنْ يُعزى ما يسمى في اللغة بــ(المشترك

$$
\text { 1) انظر : دلالة الألفاظ لإبر اهيم أنيس صـمب. }
$$

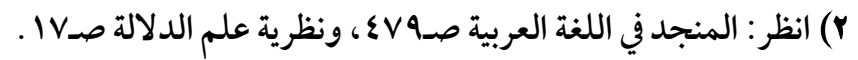

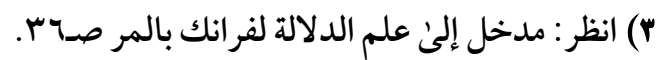

$$
\text { \&) التعريفات للجرجاني صدrV. }
$$

0) انظر حول هذا المفهوم: الأسس الإبستمولوجية والتداولية للنظر النحوي عند سيبويه،

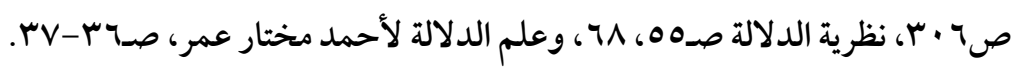
1) انظر حول هذا المفهوم: نظرية الدلالة صدץr. 


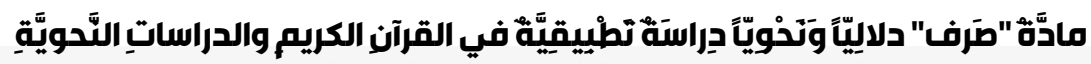

اللفظي) و المر اد به: "اللفظ الواحد الدالّ على معنيين مختلفين فأكثر، دلالةً على

$$
\text { السواء عند أهل تلك اللغة"(1) - (1) . }
$$

ومفردة"الصَّرف" التي هي موضوع هذه الدراسة، تأتي في إطار هذا النوع من

أنواع الدراسة اللغوية، من حيث هي مشتركك لفظيٌّ ثريّ الوظائف في علم الدلالة، وستشمل الدراسة صيغها ومشتقاتها، وما لها من دلالة معجمية، ونحوية، واستعمالاتها القرآنية، واصطلاحات علماء النحو المأخوذة من هذه المادة، ومعانيها العلمية وكيفيات توظيفها.

\section{مجال اللدراسة وحلدودها :}

المجال الذي هو ميدان هذه الدراسة ومدار رحاها هو: الدلالة والصرف والنحو، من حيث ورود هذه اللغوية ومعالجتها في علم الدلالة المعجمية، والصرفية، والنحوية نظريَّا، وتطبيقيًا على ألفاظ القرآن الكريم، وكلام العرب نثرًا وشعرًا، ومصطلحات علماء اللغة والنحو، والمعالجات النحوية والصرفية لهذه المادة وفروعها في كتب النحو والتصريف.

\section{مشكلة البحث:}

قصور الفهم الحقيقي لدىن بعض الدارسين اللغويين، أو المنتمين للغة العربية لـمادة "صرف" من جهة مكانتها وأثرها في الدلالة اللغوية، والاصطلاحات النحوية، وخفاء العلاقة القائمة بين معناها الأصلي (المركزي) ومشتقاتها وامتداداتها الدلالية في النصوص العربية، وفي مجالَي التواصل التداولي والاصطلاح نجد تضييقًا لدلالتها لدىن هذه الفئة من الناس، أو المنتمين للغة العربية، بل كثيرًا ما نجد من يقصر مصطلحات:(الصرف ـ التصريف ــ التصرف

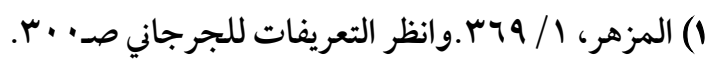




\section{مجلة كلية اللغة العربية بالمنوفية العدد الخامس والثلاثون - إصدار ديسمبر 2020م}

\section{ग19}

ــ الانصراف) على المستون الصرفي فقط من الدراسات النحوية، ويرفض أن تكون لها وظائف دلالات تركيبية، ونجد مثل هذا التضييق لهذه المفردة على

مستوى السياقات المختلفة!

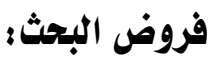

تفترض هذه الدراسة أن مادة "صرف" ذات دلالة واسعة مؤثرة على المستويات السياقية التي ترد فيها في النصوص العربية بعامة، وعلى المستوكن المعجمي، والمجالات النظرية في الدرس النحويّ، وأنها في القرآن الكريم استُعملت على نطاق واسعٍٍ قد يُمَكِّن الباحث من الكشف عن كثير من عُمقها اللغوي في المجال الاستعمالي، كما تفترض الدراسة أن التوصل إلى العلاقات الرابطة بين استعمالات كلمة "صرف" السياقية في القرآن الكريم، ودلالاتها المعجمية، سيؤدي إلى إثراء الدلالة اللغوية والصرفية والنحوية، كما أن الوقوف على دلالاتها بشكل واسع سيقود إلى توسع في دراسة مثيلاتها من المواد العربية على المستوئ التطبيق، وسيحاول البحث التحقق من هذه الفروض علميَّا إن شاء الله.

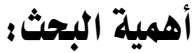

تَضِحُ أهميةُ هذا البحث فيما يُسهم به من إثراء للدراسة الدلالية في اللغة

العربية، والربط بين المستون المعجمي للمفردة اللغوية، والدراسة النظرية التركيبية، وفي تبيان أثر المعاني القرآنية لهذه المادة اللغوية في المستوى الاستعمالي التطبيقي، والمجالات اللغوية التي تطورت فيها دلالاتها تعميمًا وتضييقا، وكذلك يُسهم البحث في الكشف عن أهمية الدراسة "المصطلحية" في الدراسات النحوية، فهذه المادة لها ورود متكرر واسع في الدراسات النحوية 


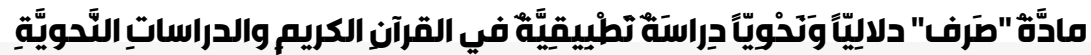

على مستوىن المفردات والتراكيب، من حيث مواطن المصطلحات التي اشْتُقت منها،ولقد استعملتُ لدئ علماء النحو بدقة عالية في كثير من المو اطن، وبتجوُّز في بعضها، وستبرز قيمة البحث أيضا في استيضاح أثر المزج بين الدلالات المشتركة في الاستعمال العلمي، والكشف عن أهمية معرفة دلالة اللفظ الجذرية في تحديد إطلاقاته في الدراسات اللغوية العلمية.

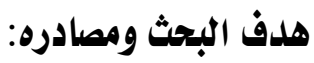

فحص حقيقة دلالة مادة "صرف" في اللغة العربية، والكشف عن مدئ تطورها الدلالي على المستوى الاستعمالي والنظري، والإسهام في إثراء الجانب الدلالي من جوانب الدراسات النحوية، و الربط بين المعاني اللغوية والاستعمال

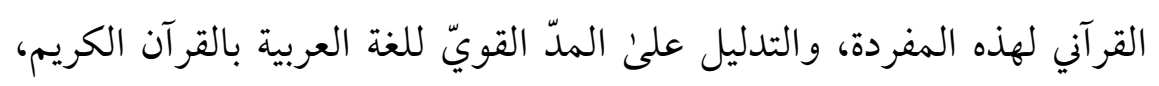
باستنباط مكامنها الحيوية الدلالية التي نجدها للمفردات في الاستعمال القرآني، ويكيفية توظيف المفردات للأغراض السياقية، وتهدف الدراسة إلى توضيح قيمة المصطلحات النحوية المشتقة من هذه المادة، وإبراز دلالاتها على مستوىن

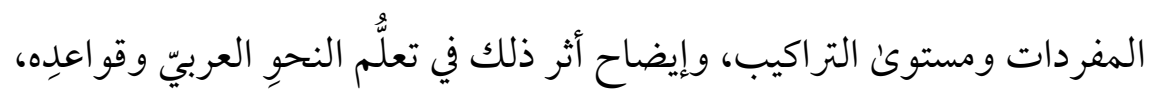
وتهدف الدراسة أيضا إلى إزاحة الفهم الخاطئ في قصر هذه المصطلحات على

$$
\text { جانب "علم الصرف" دون النحو. }
$$

ولأجل التأصيل اللغوي والعلمي لهذه الأمور كلها ركزتُ في دراستي على:

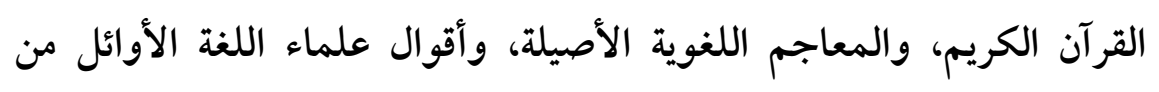
المعجميين والنحويين، والمؤلفات التي هي مصادر الدراسات العربية اللغوية، مثل: علماء القرون الهجرية الثاني والثالث والر ابع، ومؤلفاتهم. 
مَنهُجْ مُزْجَ فيه الاستقراء بالوصف، والاستدلال بالإحصاء ثم الاستنتاج،

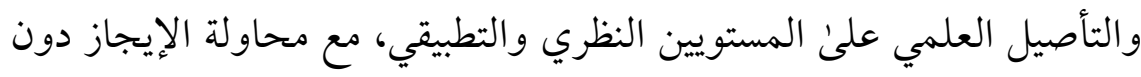

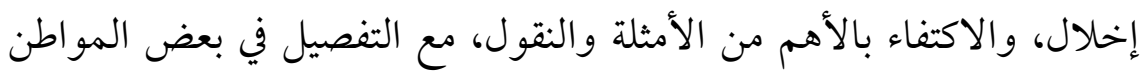

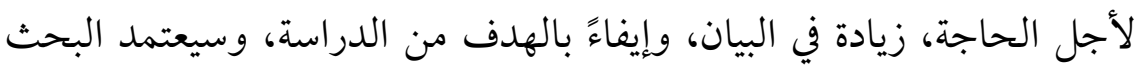

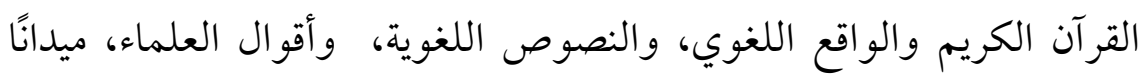

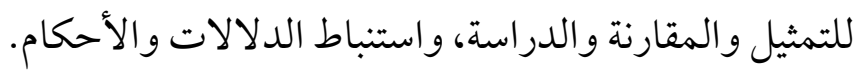

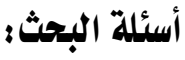

\section{سيجيب البحث عن جمع من الأسئلة، من أهمها :}

ما طبيعة الدلالة اللغوية لمادة"صرف" البحن على المستوئ المعجمي، والنحوي، والسياقات الاستعمالية؟ وما الجذر الأصلي لهذه الدلالة؟ وكيف نثبت أثرها اللغوي على المستوى النحوي بمفهومه الشامل؟ وهل توسَّعت دلالتها فامتدت وتطوَّرت قليلا أو كثيرًا؟ وما علاقة دلالتها الجذرية باستعمالاتها السياقية في

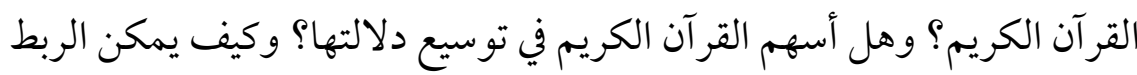

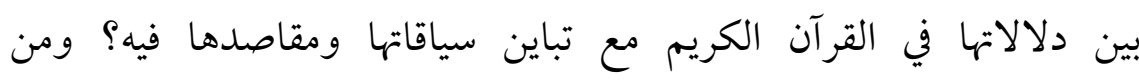
المصطلحات الشائعة في الدراسات النحوية: مصطلحات مشتقة من مادة

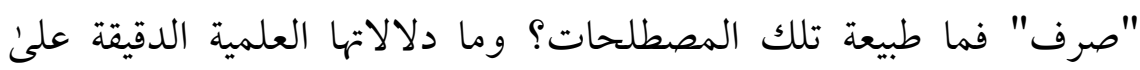
المستوئ النظري والتطبيقي؟ وكيف ترتبط بالدلالة اللغوية الجذرية لهذه

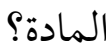




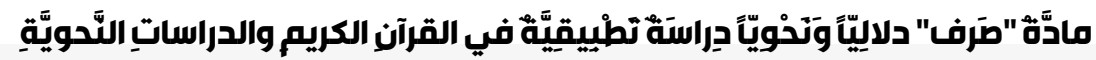

\section{OAC P}

\section{هيكل البحث:}

يتكون البحث من مقدمة محتوية لطبيعة موضوعه، وخطته وعناصره، ثم ثلاثة

$$
\text { مباحث رئيسة: }
$$

الأول: بيان التأصيل المعجمي لدلالة مادة "صرف" ومعانيها الاستعمالية المشتركة عند العرب، والمعاني المجازية التي توسعت إليها. والثاني: إحصاء للصيغ والمشتقات الواردة في القرآن الكريم من هذه المادة، ودراسة دلالات سياقاتها بالتفصيل.

والثالث: المصطلحات العلمية المشتقة من هذه المادة في الدراسات النحوية، وإيضاح مفصل لعلاقة كل مصطلح بالدلالة الجذرية للمادة، والربط بين استعمالاتها النظرية والتطبيقية لدىن علماء النحو، وأثر ذلك في الأحكام الصرفية والنحوية.

وتخلل هذه المباحث الثلاثة الرئيسة تفريعات متصلة بكل واحدٍ، اقتضتها الدراسة لأجل الاستقصاء العلمي لما ترتبط به دلالة المادة اللغوية، وسيقف البحث على موقف الدراسات الحديثة، وتناول اللغة العربية المعاصرة لهذه المادة، في المجال العلمي والتواصلي بما يوضحه في كل شيء مما تقدم، ثم

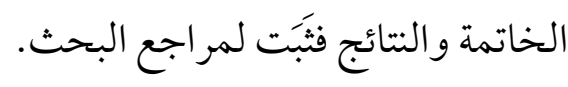

\section{الدراسات السابقة}

وقفت على موضوعات متنوعة ومتعددة، يتناول بعضها معنى كلمة "صرف"

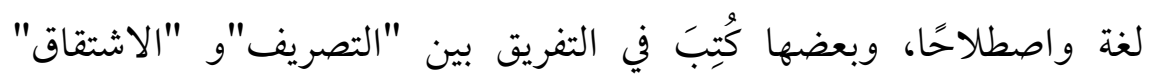
وبعضها في مفهوم "الصرف" عند المتقدمين والمتأخرين، وبعضها في موضوعات علم الصرف ومباحثه. ولم أقف ــ حسب اطلاعي ـ علىن دراسة 


\section{مجلة كلية اللغة العربية بالمنوفية العدد الخامس والثلاثون - إصدار ديسمبر 2020م}

متخصصة تتقاطع مع دراستي تقاطعًا مؤثرًا ولا مغنيًا عنها، وعامة ماوقفت عليه إما مقدمات لكتب في الصرف، أو مقالات موجزة، أو دروس في التعريف

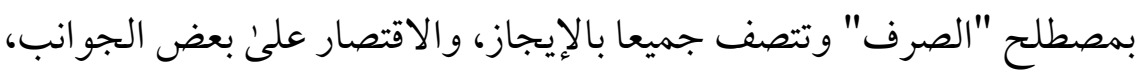
و والاكتفاء بالنقل ـ غالبًا ــ وقلة التطبيق علئ النصوص اللغوية.

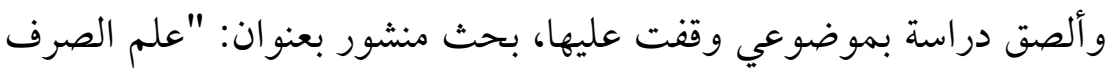

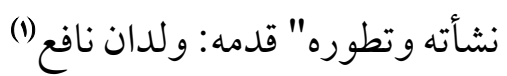

عرّف فيه الباحث بمصطلح "الصرف" ونقل بعض ما قيل فيه قديمًا وحديثا، ثم عرض لمراحل تطور الدراسات الصرفية في تاريخ التأليف العربي، وناقش فئش

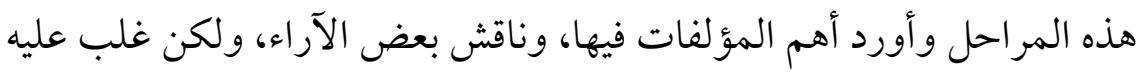

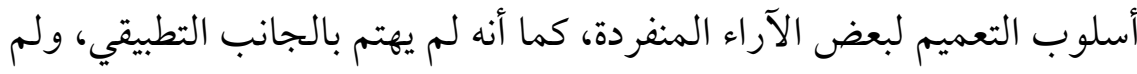

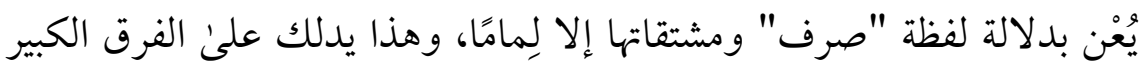
بين بحثه ودراستي.

1) Wildan Nafi'i Sekolah Tinggi Agama Islam Nahdlatul Ulama (STAINU) Madiun Email: nafiiwildan@gmail.com 


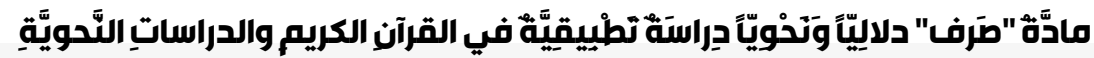

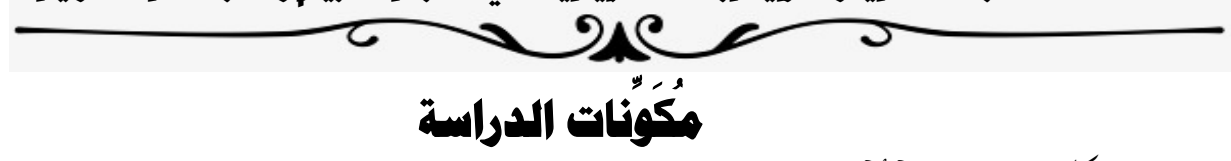

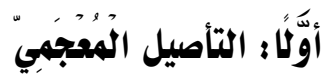

المر اد بالتأصيل المعجميّ حصٌرُ الدلالات الأصلية وما تفرّع عنها وإحصاؤها

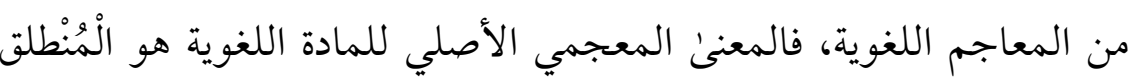

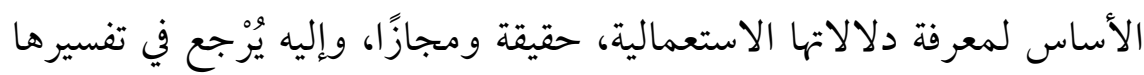

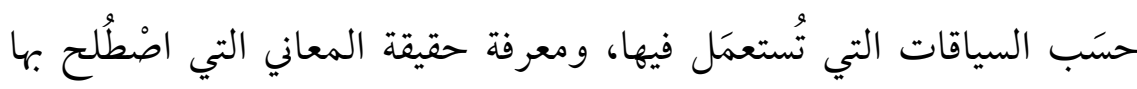

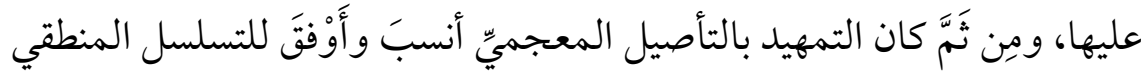

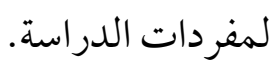

الدلالات المحورية لمادة "صَرف" ـ بفتح الصاد ـ تدور على معانٍ شديدةٍ

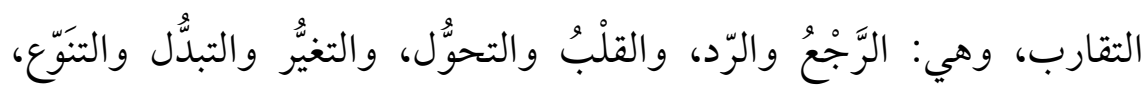

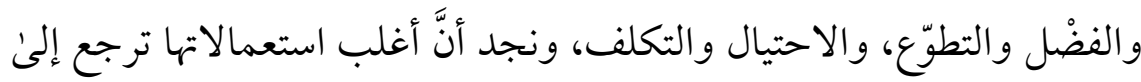

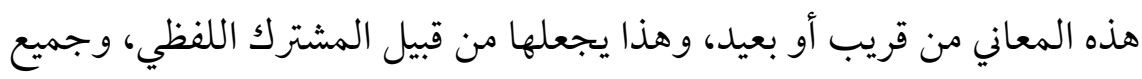

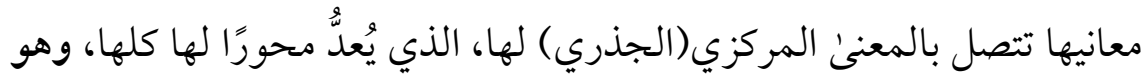

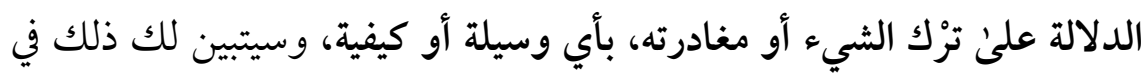

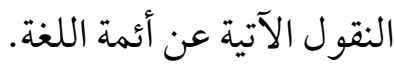

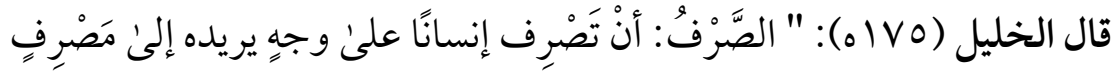

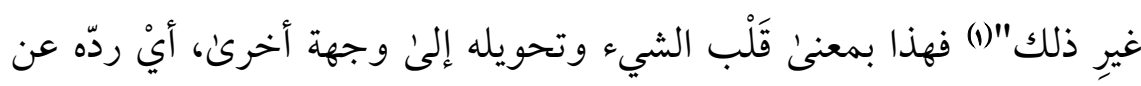

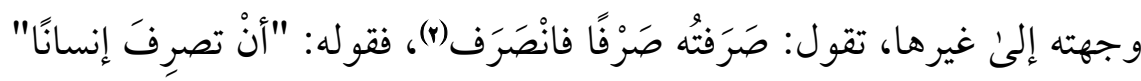

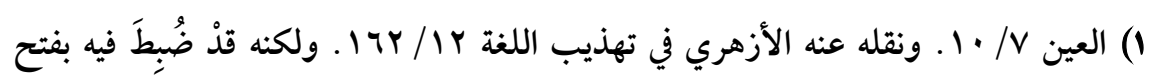
الراء"الصرَف" ويبدو أنه تصحيف؛ لمخالفته لسائر الأصول.

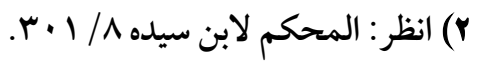




\section{مجلة كلية اللغة العربية بالمنوفية العدد الذامس والثلاثون - إصدار ديسمبر 2020م}

\section{0}

معناه أن تَقِبَهَ فتغيرَ وجهته، وهذا هو الرد والرَّجْع، وهو يقتضي التبديل والتغيير

$$
\text { والتحويل إلى حال أخرىن أو جهة أخرىن. }
$$

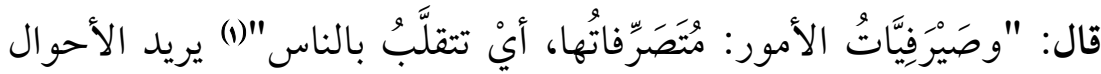

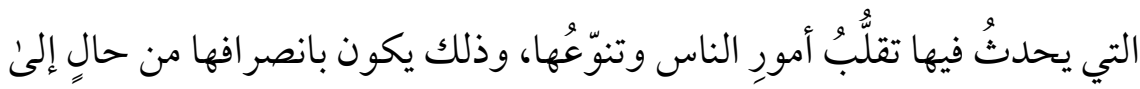

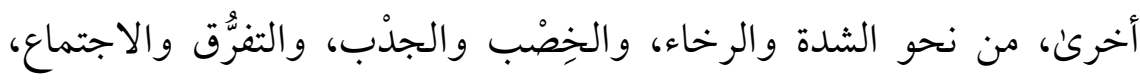
و الحرب و السِّم، وأمثال ذلك.

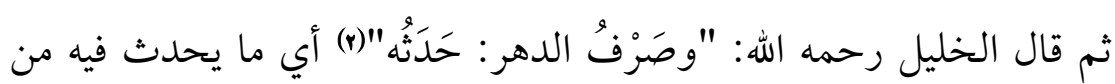
التقلبات وتحوُّلات الأمور، ولذلك سُميت نوائب الدهر ومصائبه بحدثان(ه)

$$
\text { الدهر وصَرْفه، و المر اد أنها تحدث فيه(غ). }
$$

وعلىن هذا الذي ذكره الخليل تتابعتْ كلماتُ المغْجمِيِّن و اللغويِّنَ، في إيراد دلالات هذه المادة، بعبارة الخليل نفسها، أوما يرادفها أو يقاربها من المعاني

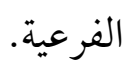

قال ابن فارس(0 9 بهـ): "الصاد والراء والفاء معظم بابه يدل علىن رَجْع

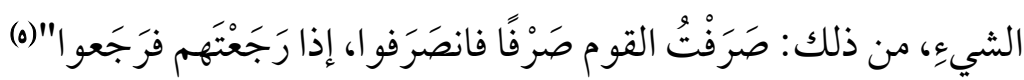

$$
\begin{aligned}
& \text { 1) العين / 1 / 1 }
\end{aligned}
$$

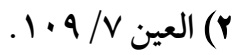

r) "حدثان" بكسر الحاء وسكون الدال، أو بفتحهما، ضبطت الكلمة بالوجهين، كما في

$$
\text { القاموس المحيط ولسان العرب(مادة: حدث). }
$$

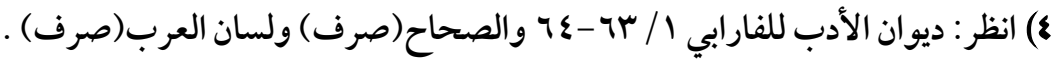

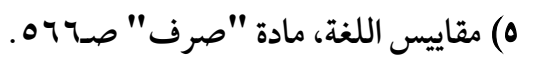




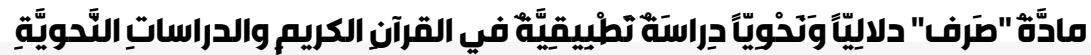

\section{ose}

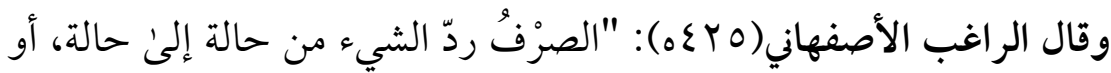

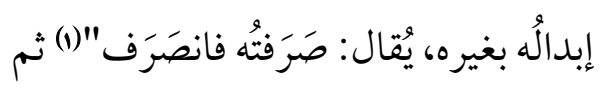

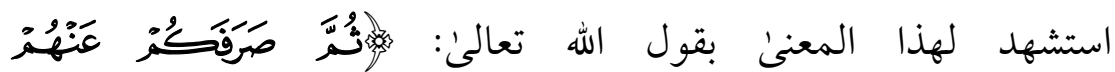

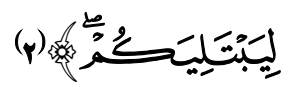

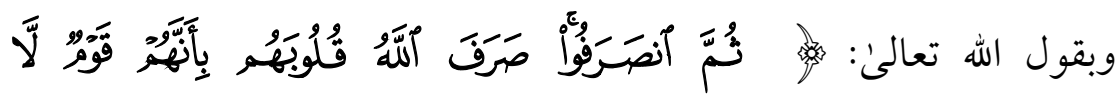

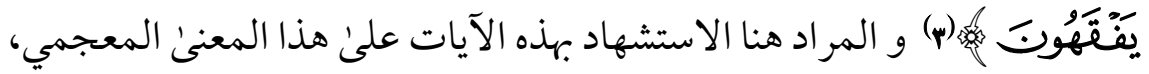
وسيأتي بعدُ إن شاء الله مناقشة المقاصد الدلالية لهذه الألفاظ في سياقاتها القرآية

جميعها.

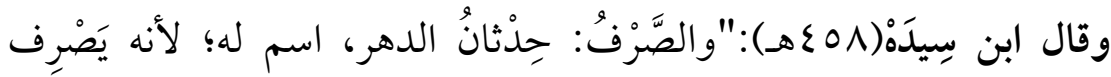

$$
\text { الأشياء عن وجوهها"(() واستشهد بقول الشاعر: }
$$

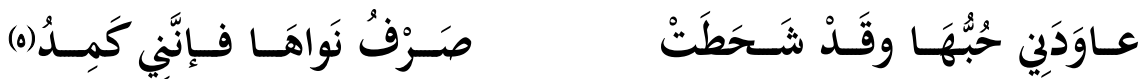

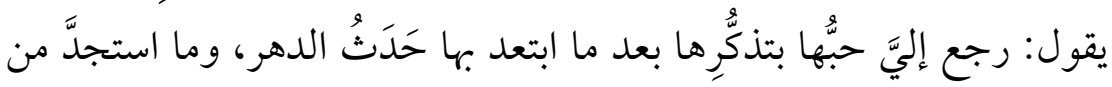
تقلبات أحو اله، حيث انتوتْ بعيدًا، فإنني شديد الحزن لذلك.

$$
\begin{aligned}
& \text { 1) مفردات ألفاظ القر آن، مادة(صرف)صدץ^ـ . } \\
& \text { r) سورة آل عمران: }
\end{aligned}
$$

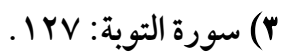

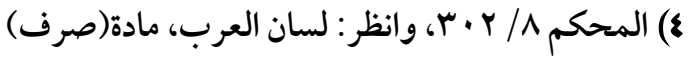

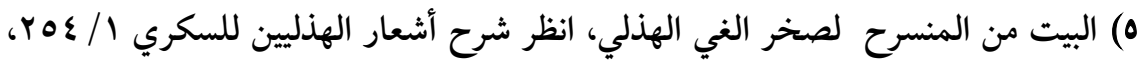

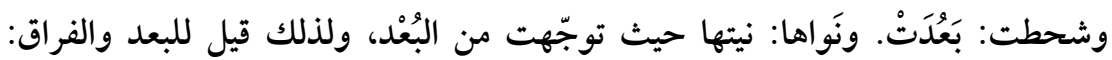

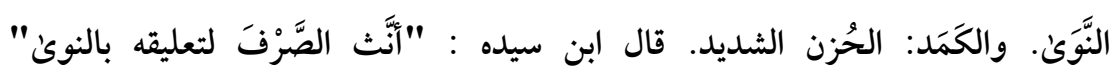

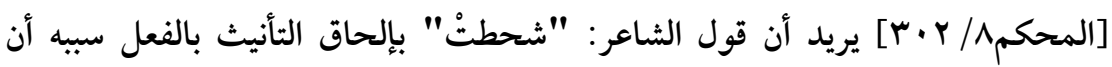

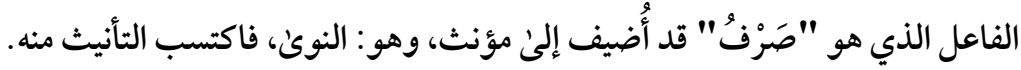




\section{مجلة كلية اللغة العربية بالمنوفية العدد الخامس والثلاثون - إصدار ديسمبر 2020م}

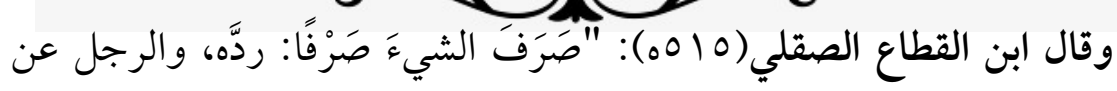

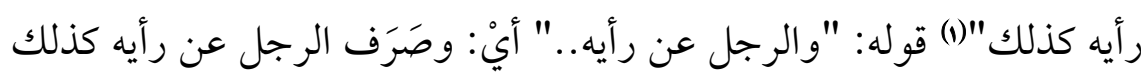
معناه: ردَّه عنه. - مانه فهذا كلُّه تبيانٌ للمعنى الذي ذكره الخليل وهو القلْب و الرّد و التحويل من وجه إلى آخر.

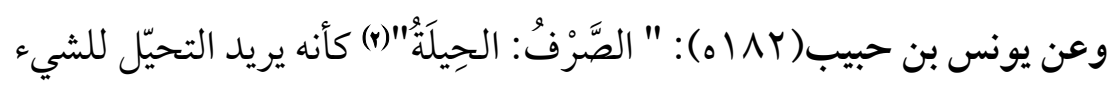

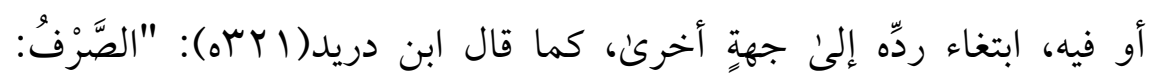

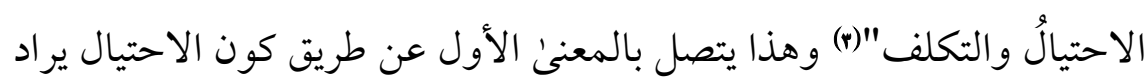

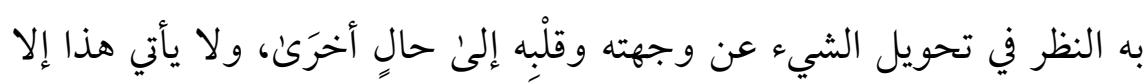

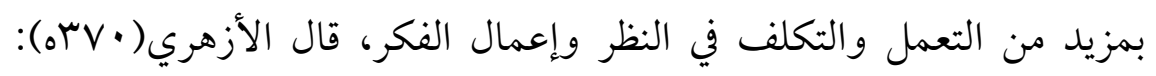

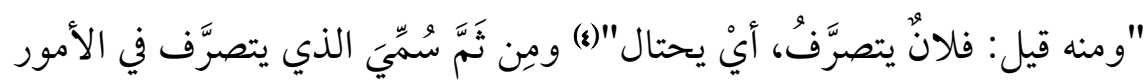

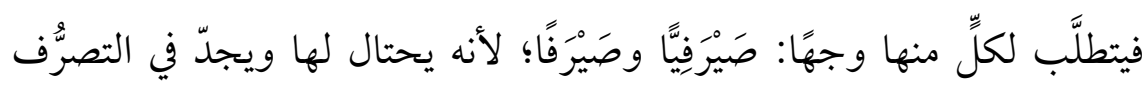

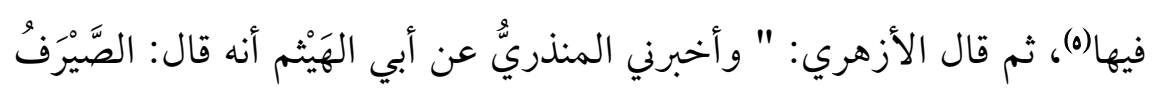

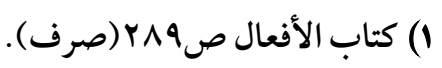

$$
\begin{aligned}
& \text { r) تهذيب اللغة r / / 1 1 1، وصحاح الجوهري (صرف) }
\end{aligned}
$$

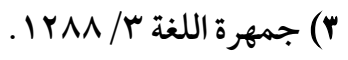

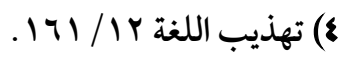

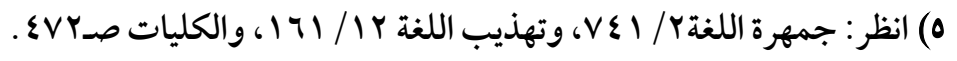




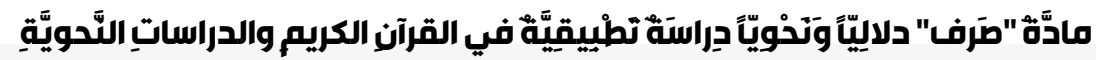

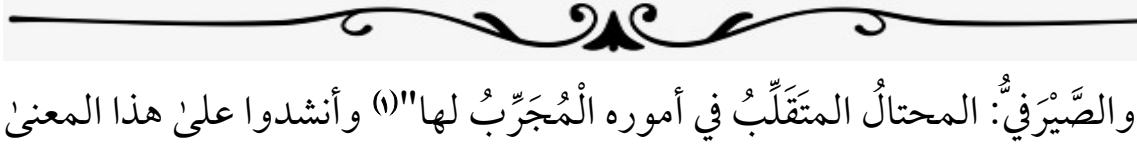

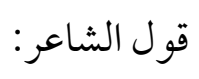

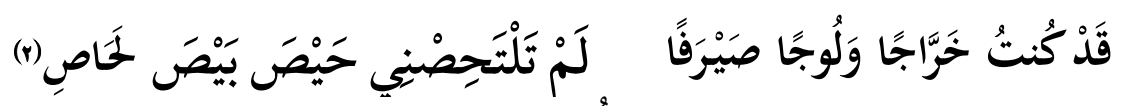

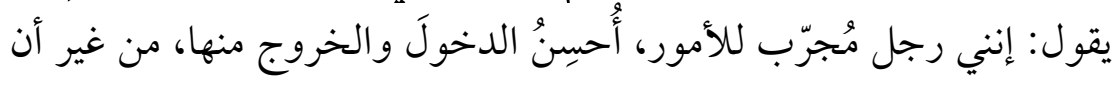
تضيق عليّ فأتورّط فيها، ولذلك سَمَّى نفسه:"صَيْرَفًا" أبيْ حَسَن التصرُّف

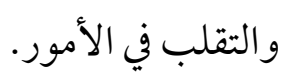

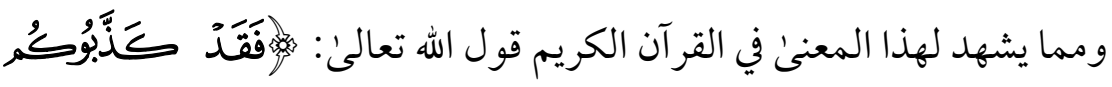

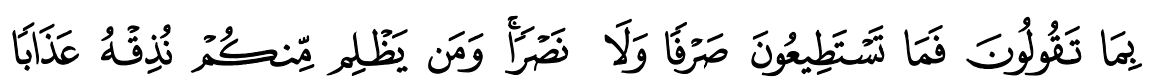

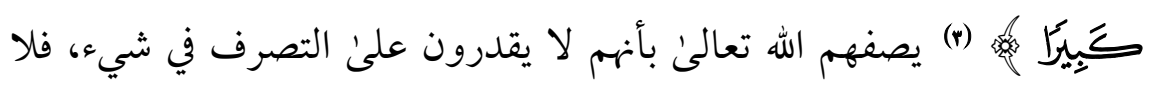

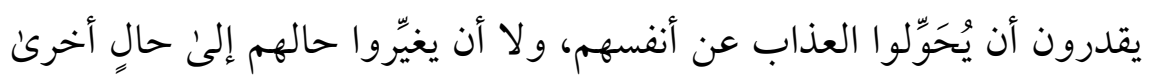

$$
\text { كما يريدون، فلا حيلة لهم في شيء (8). }
$$

$$
\text { 1) (ب) تهذيب اللغة، الموضع السابق. }
$$

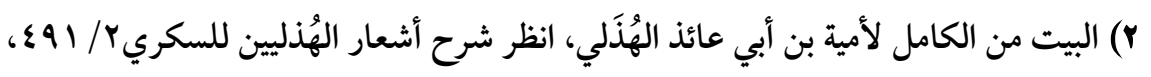

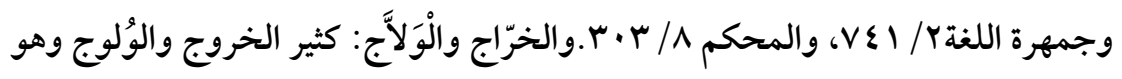
الدخول. والَّلحاص: الضِّيق والشدة، ومنه قوله"لم تلتحصني" أي لم تَضِق علي الأمور

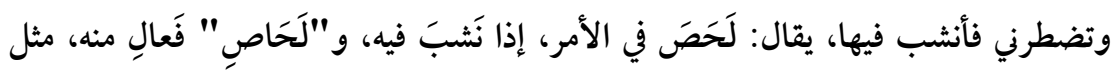

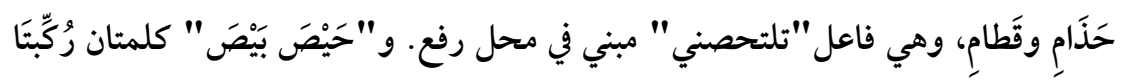

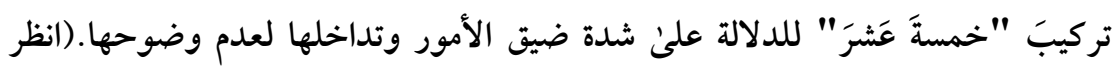
الموضعين السابقين شرح أشعار الهذليين، ومن الجمهرة) .

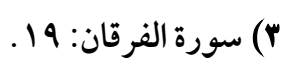

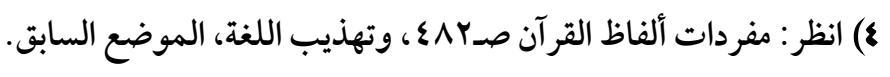




\section{مجلة كلية اللغة العربية بالمنوفية العدد الذامس والثلاثون - إصدار ديسمبر 2020م}

\section{ग1C}

ومن هذا المعنى قولهم: صَرَف لأهله، واصطرف لهم، إذا سعن لهم، بمعنى كَسَب وطلبَ واحتالَ(1)؛ لأن هذا كله من التصرُّف بالتقلّب والاحتيال لأجل

الكسب.

\section{التوسع بِ دلالتها واستعمالاتها المجازية}

وقد توسَّعَتْ العَربَ في دلالة هذه الكلمة، فاستعملتها وما اشتَّقَّ منها لِمعانٍ ترجع إلى الأصل المتقدم مباشرة، وأحيانًا إلى ما يُلابسه بطريقة غير مباشرة، وهذا من مرونة العربية وقوتها في الاشتقاق، ومن أشهر ذلك غير ما تقدم ما يلي: ا ـ تسمية التوبة صَرْفاً(r)؛ لأن التائب يَرْجِع عن معصيته، ويدخل مع أهل

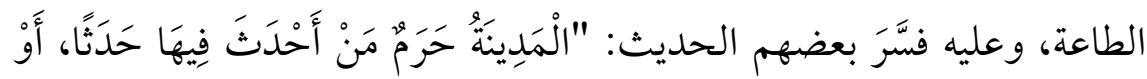

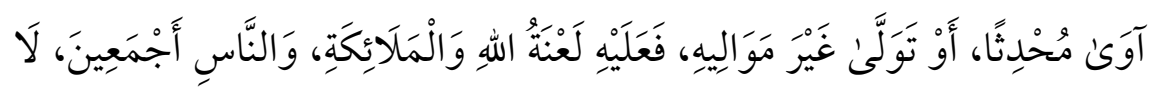

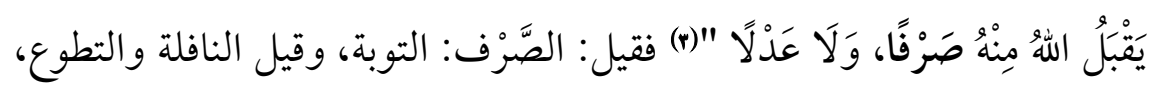
وقيل الاكتساب، وقيل الحيلة، والعدل الفريضة أو الفدية(() وقيل غير ذلك(ه)،

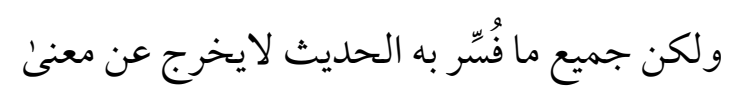

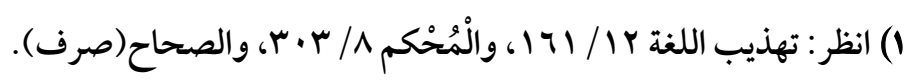
r) انظر: ديوان الأدب // /7، ومقاييس اللغة صـ7דه ، وكتاب الأفعال لابن القطاع

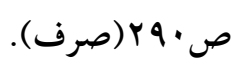

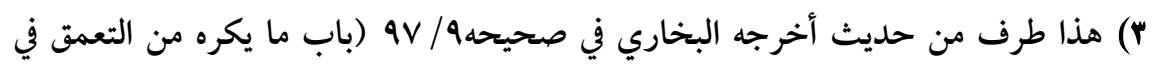

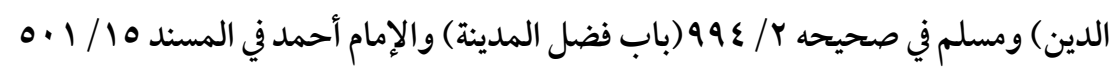

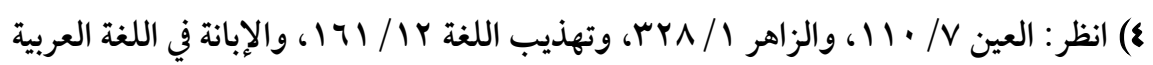

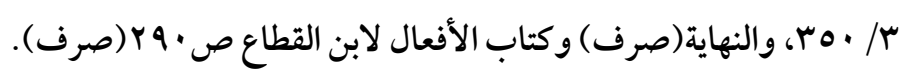

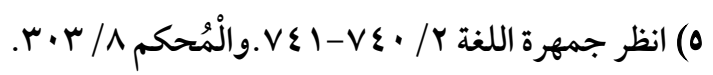




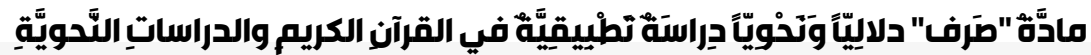

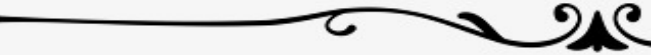

الرجوع عن الشيء إلى غيره، وهو نوع من التحول من حال إلى أخرىن.

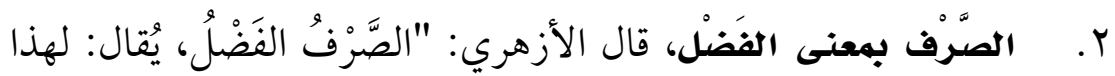

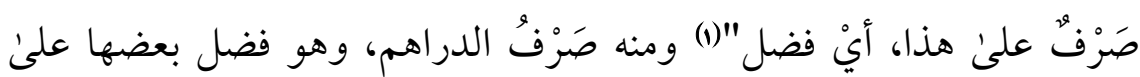
بعض في القيمة والجودة(r)، قال ابن فارس رحمه الله مُعلقًا على هذا المعنى:

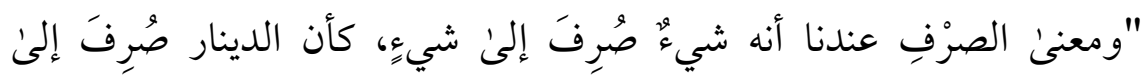

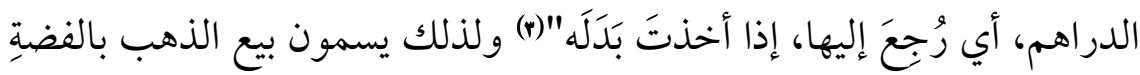

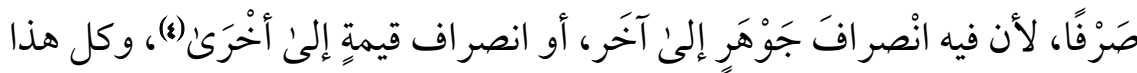
من التقلب و الرد و التحوُّل، ولكن بتوسُّع في الاستعمال.

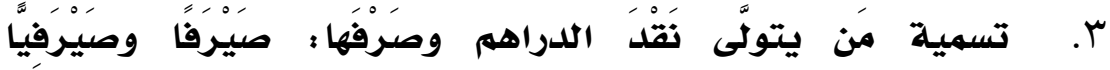

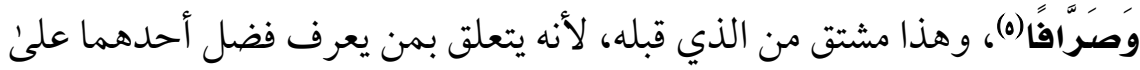

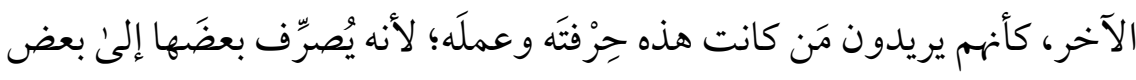

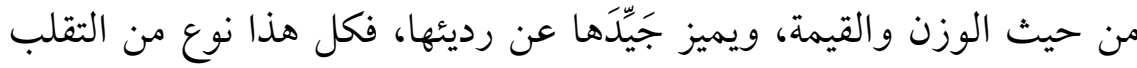

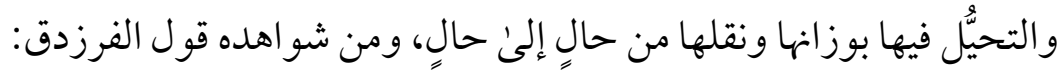

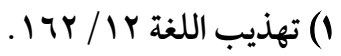

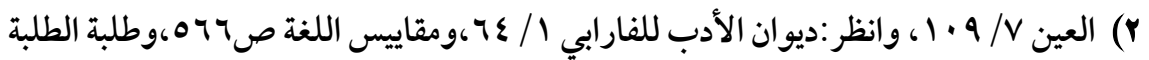

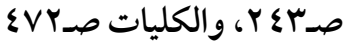

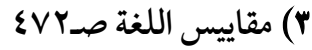

$$
\begin{aligned}
& \text { §) انظر لسان العرب 9 / } 9 \text { (صرف). }
\end{aligned}
$$

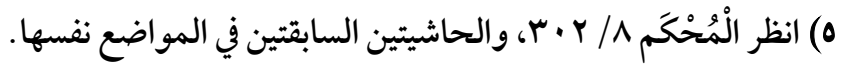




\section{مجلة كلية اللغة العربية بالمنوفية العدد الذامس والثلاثون - إصدار ديسمبر 2020م}

ब1e

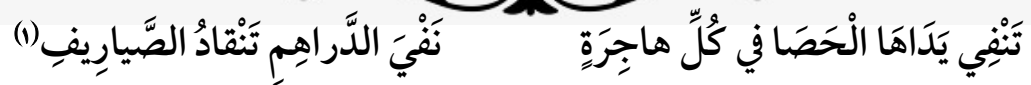

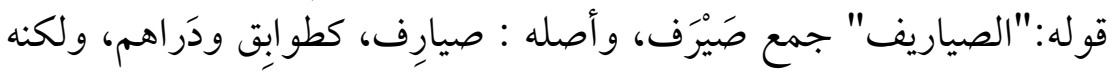

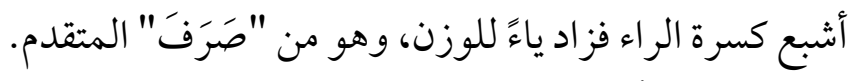

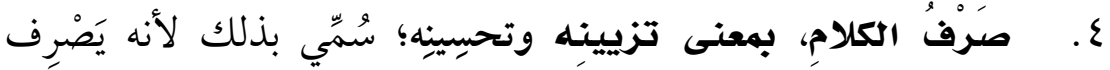

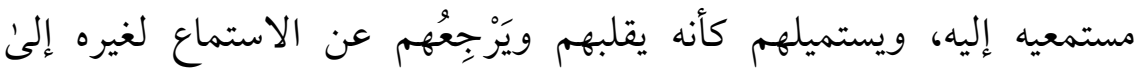

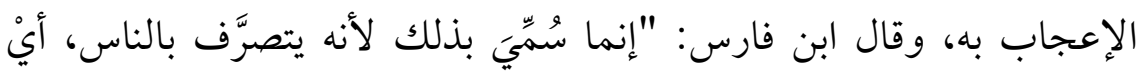

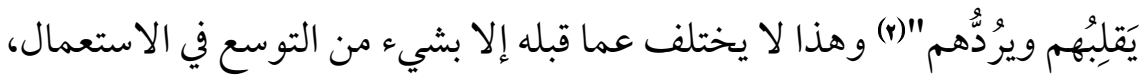

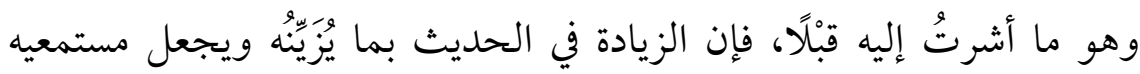

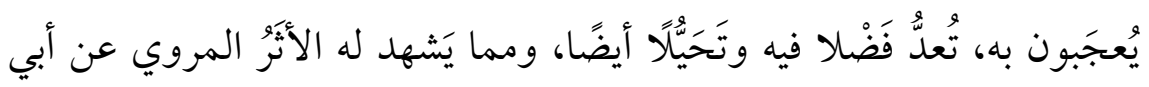

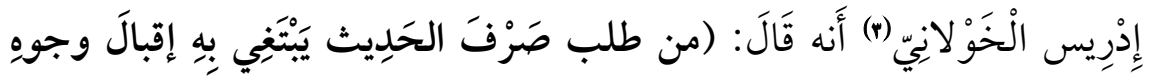

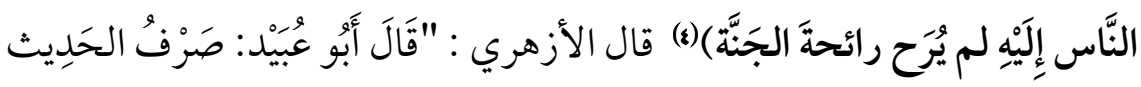

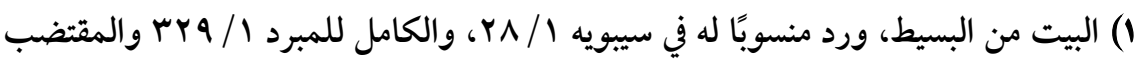

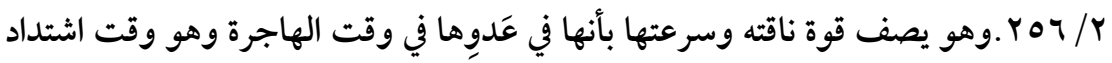

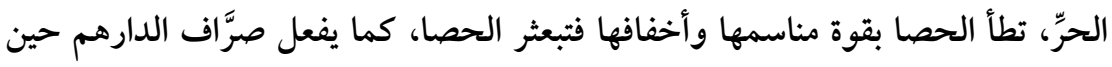

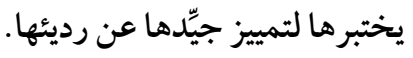

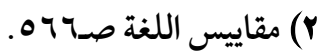

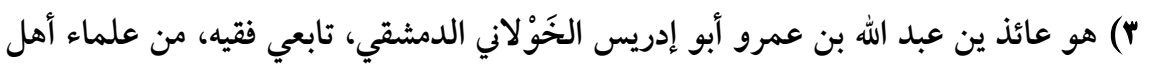

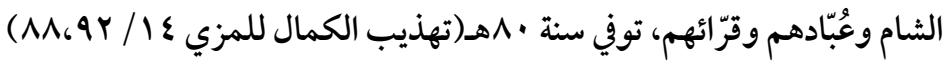

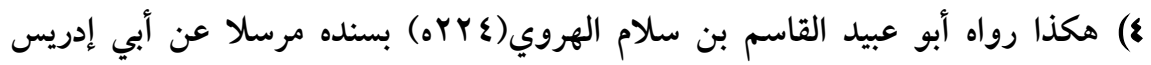

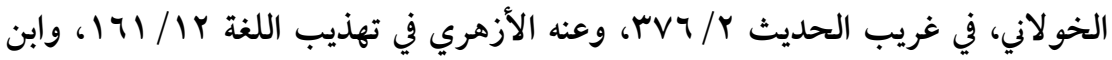

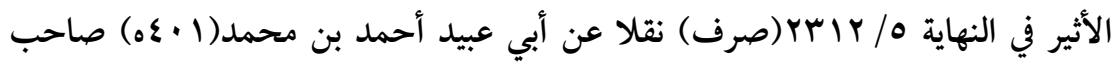

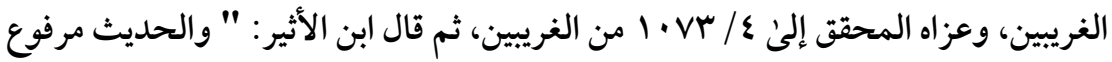

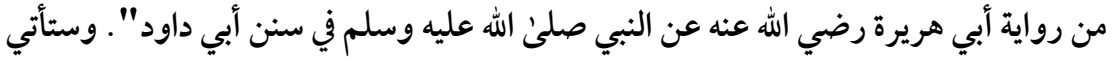

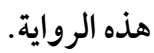




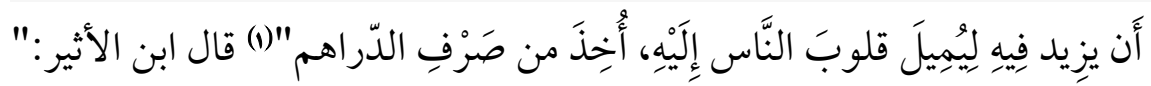

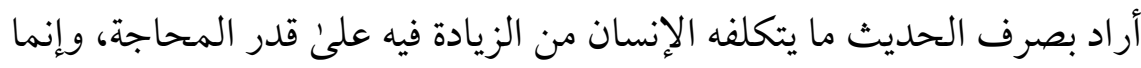

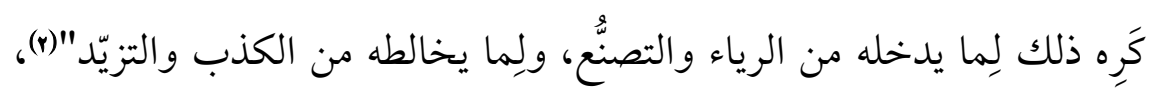

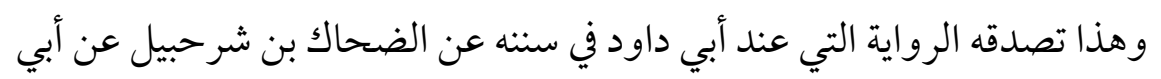

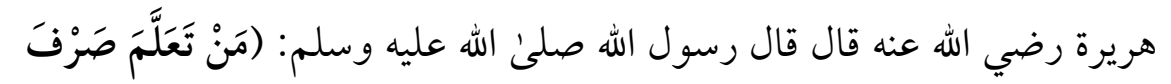

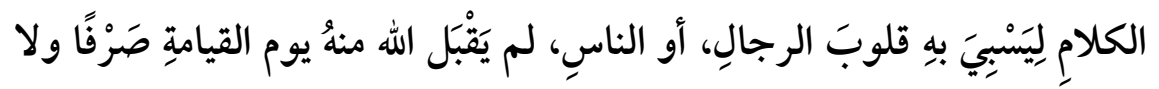

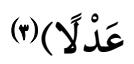

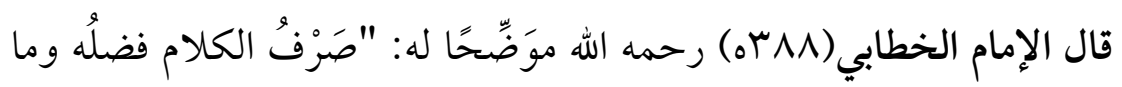

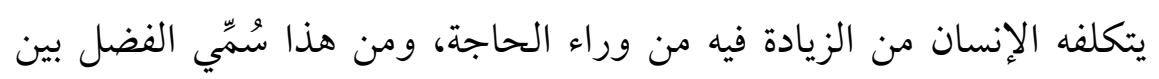
النقْدَيْنِ صَرْفَا فقد حمل هذا الاستعمال معنيين هما التصرف في الكلام بشيء من التكلف فيه وتزيينه، وهذا يتبعه المعنى الآخر وهو استمالة قلوب الناس بذلك وقَّلَبْهُ إلىنى

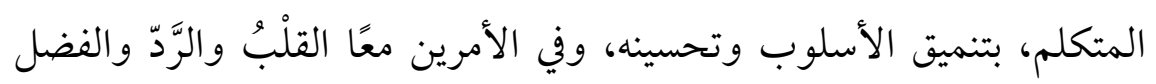
و الزيادة والتحيُّل، ولكن بشيء من التوسع و التنويع في الاستعمال.

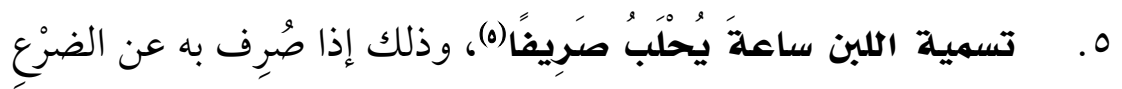
وسَكَنَتْ رغوتُه()، وذكرَ الأزهري عن الأصمعي أنه إذا سكنت رغوته فهو

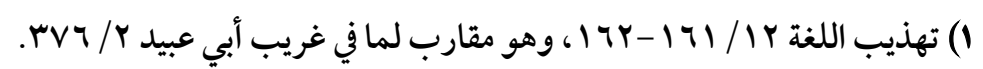

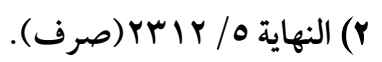

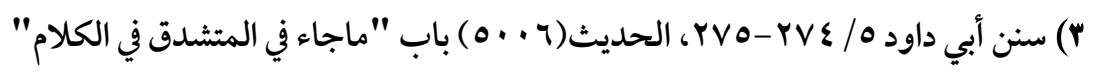

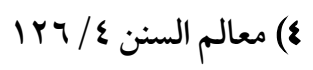

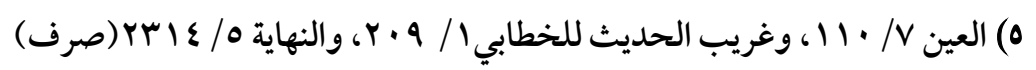

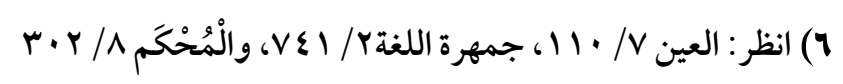




\section{مجلة كلية اللغة العربية بالمنوفية العدد الخامس والثلاثون - إصدار ديسمبر 2020م}

\section{ग19}

الصريح (1) وهذا أوجه؛ لأنه إذا صفا من الرغوة صَرُحَ وصارَ محضًا صافيًا، ومن

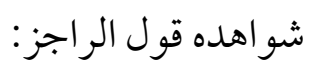

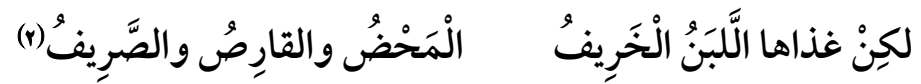

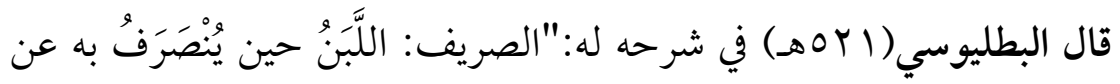

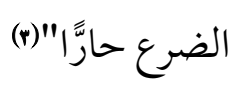

وأوَّكَه الراغبُ الأصفهاني بأنه سُمِّي بذلك لانصراف الرغوة عنه، أو لانصرافه

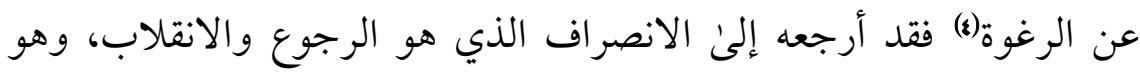

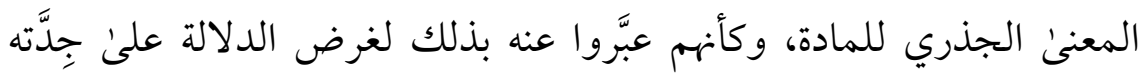
وجودته.

7. تسمية الصوت صَرِيفًا، وأكثر ما يستعملونه في أصوات الأنياب والآلات، كالأقلام والبكُرةة والأبواب ونحو ذلك(ه)، ولعل ذلك لكون أصواتها

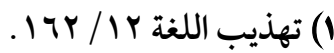

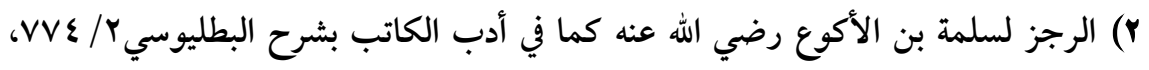

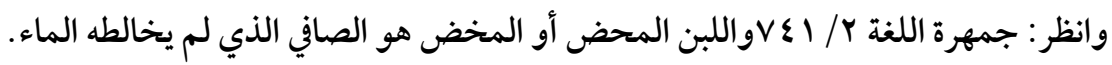

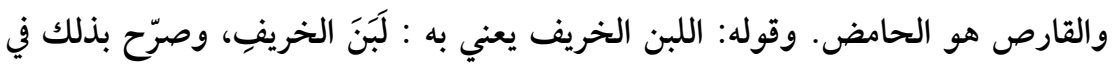

$$
\text { بعض الروايات على الإقواء. }
$$

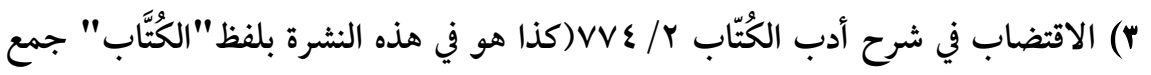

$$
\text { كاتب). }
$$

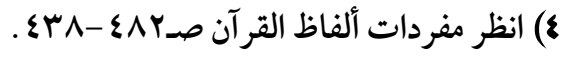

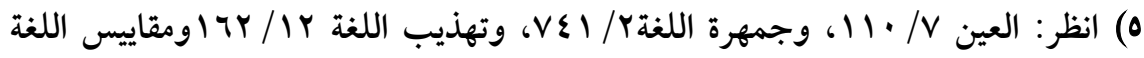




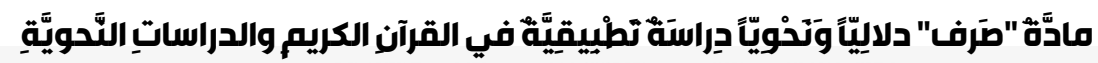

تحصل بترداد وترجيع، ومن شواهده مارُوي عن الرسول صلىi الله عليه وسلم

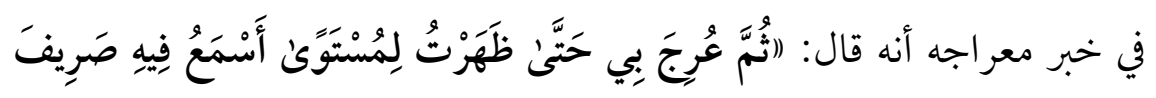

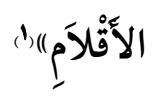

قال الحافظ أبو موسن الأصفهاني(1) صوت جَرَيانِها بما تكتبه الملائكة من أقضية الله عزّ وجلّ، وما يتستخونه من اللوح المحفوظ، أومما شاء الله عز وجل أن يكتب من ذلك ويُرفع لِما أرادَ مِن أمْرِه وتدبيره في خَلقه"((r)، قال: "والصريفُ أيضًا صوْتُ يُسمع من وقْع الأسنان بعْضِها علىن بعض، يُقال صَرَفَ البعيرُ نابَه صَريفًا"((r) وقال الجوهري: "وصَريفُ

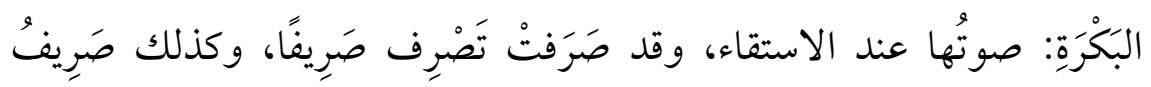

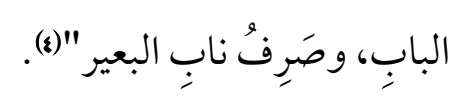

ومن شو اهده قول النابغة الذبياني يصفه ناقته:

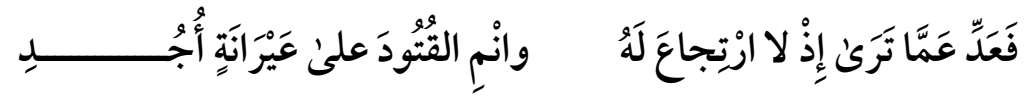

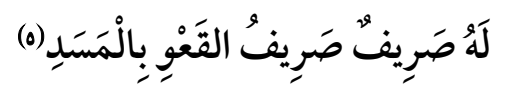
مقْذوفَةِ بَدَخِيسِ النَّحْضِ بِازِلْها

1) أخرجه البخاري في صحيحه V/ V1/(باب كيف فُرضت الصلاة في الإسراء) ومسلم في

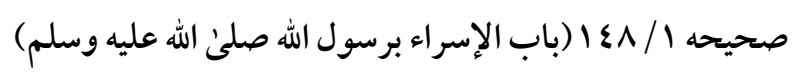

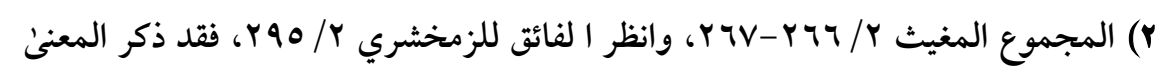

$$
\begin{aligned}
& \text { نفسه في خبر آخر. } \\
& \text { r) السابق نفسه. }
\end{aligned}
$$

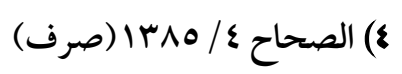

0) بيت من البسيط، من معلقة النابغة التي مطلعها: 


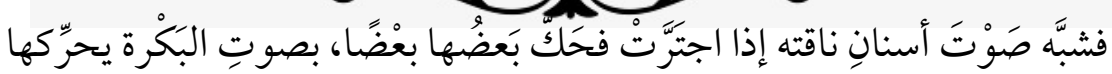

$$
\text { الحبل فتدور حول محور ها بالصرير. }
$$

وذكر بعض الشراح نقلا عن الأصمعي وغيره أن هذا الصوت يصدر من الناقة عند كَلالها وفتورها، ولذلك عَقَّبَ ابن منظور علىن بيت النابغة بقوله: "هو وعيره

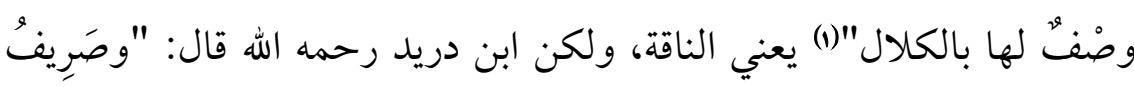
الناقِة إعياء، وربما كانَ أينًَا، وربما كان نشاطًا"(r) فذكر أنه قد يكون دليلا علىن النشاط، وهذا هو الأوفق ببيت النابغة؛ لأنه يصف ناقته بالنشاط والقوة، حتى إن بازلها إذا صكَّتْ به آخر كان له صوتُ قوي كصوت البكرة في القعوِ، ولذلك قال أبو جعفر النحاس(^شبه) : "ولا يكون الصريف في بيت النابغة إلا من النشاط والفرح"(() فهذا هو الأليق بتفسيره، والسياق يقيد مطلق معاني الألفاظ. V. تسمية اشتقاق شيء من شيء تَصْرِيفًا(8)، والسبب في هذا أنه إذا أُريدَ

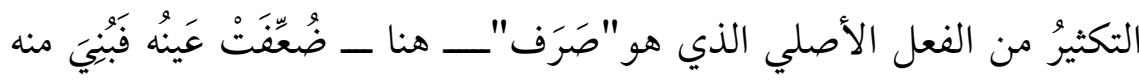

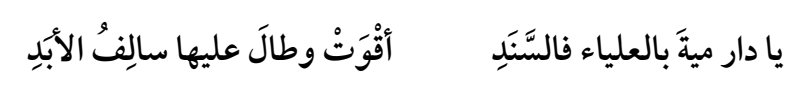

(انظر ديوان النابغة الذبياني صده-7) وقوله: فعَدِّ: انْصَرِفْ. وانْمِ ارفَفْع. القُتُود: عِيدَانِ الرَّحْل.

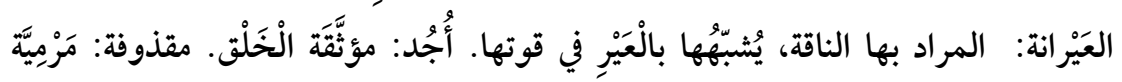

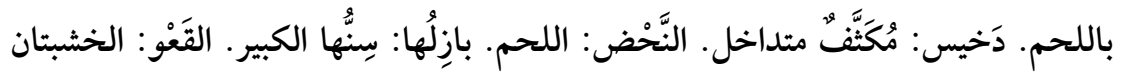

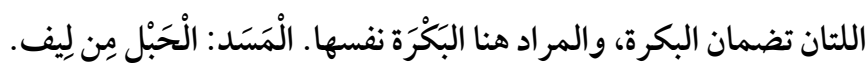

$$
\begin{aligned}
& \text { 1) لسان العرب /919 (صرف) }
\end{aligned}
$$

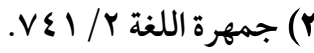

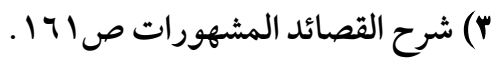

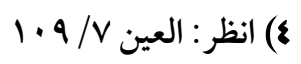




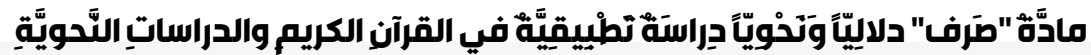

\section{-}

"فَعَّل " ومصدره "التفعيل "ثم يُطْلَق على ما جاء من تكثير فِعِله، كاشتقاق الشيء من الشيء، فيقال هذا تصريفٌ، كأنه تكثير من الصَّرْفِ، لأنه حصل بالتقليب والترجيع والتحويل، ونحو ذلك مما تقدم من المعاني الأصلية لهذه المادة، ولذلك يُطلَق "التصريف" مُرادًا به التنويعُ والكثرة والرَّجْع مرّاتٍ متعددة، قال

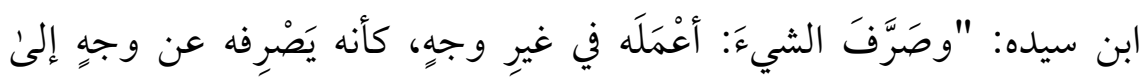
وجٍِ"(1) ومنه تصريف الآيات بييانها وتنويعها ، وتصريف الرياح، وتصريف السيول، وتصريف الكلمات، وتصريف الدراهم بإنفاقها ونقدها، ونحو ذلك

$$
\text { مما يدل على تحويل الشيء وصَرْفِهِ من حالٍ إلى أخرىن(ه). }
$$

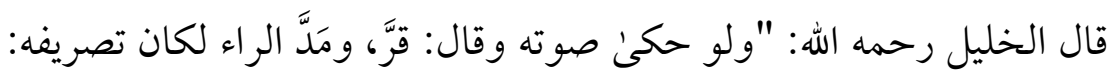

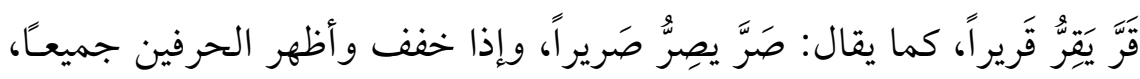
تحول الصوت من المد إلى الترجيع فضوعف لأن الترجيع يضاعف كله في

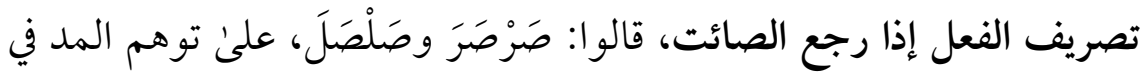

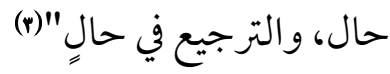
تضمَّن كلام الخليل هنا تقريرًا لهذا المعنى ببيانه معنى "التصريف" تمثيلًا، ثم ذكْره للأصل الذي نشأ منه وهو تضعيف عين الفعل، ثم بيَّن دلالة التضعيف لمريف وسببه وهو ترجيع الصوت وترديده وتكثيره، ثم ذكر أن ذلك يُفضي إلى التنويع

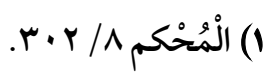

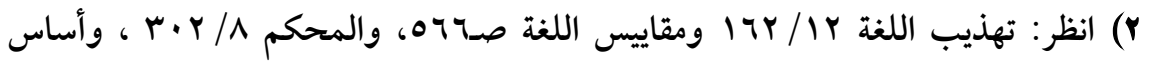

$$
\begin{aligned}
& \text { البلاغة / 0ـ 0(صرف). } \\
& \text { r r العين }
\end{aligned}
$$




\section{مجلة كلية اللغة العربية بالمنوفية العدد الخامس والثلاثون - إصدار ديسمبر 2020م}

بانتقال الصوت من حالٍ إلىن أخرىن، وهذا البيان اللغوي هو منشأ ما استُعملت له هذه المفردة في الدراسات النحوية بعامة، كما سيتبين بعدُ إن شاء الله.

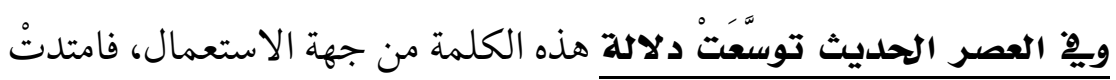

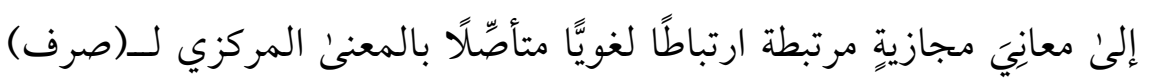

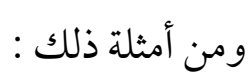

$$
\text { صرَفَ همَّه إلى كذا: أي عَنِي به واهتمّ. }
$$

$$
\text { وصرَفْتُ له مبلغًا من المال: أيْ أعطيته إياه. }
$$

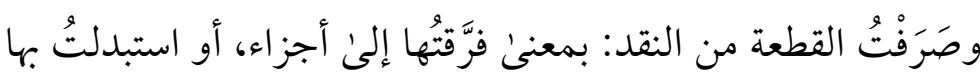

$$
\text { غيرَها. }
$$

$$
\text { وصرَف إليه وجهه: أيْ اتجه إليه والتفت إليه. }
$$

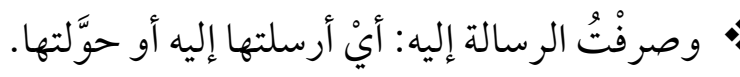$$
\text { و وانصرفنا من العمل: بمعنى رجعنا منه. }
$$$$
\text { و وانصرف الطلاب: أيْ رجعوا من المدرسة. }
$$

$$
\text { وصرف وقته في القراءة: بمعنى قضاه في القراءة. }
$$

وصرف ماله على عياله: أي أنفقه عليهم.

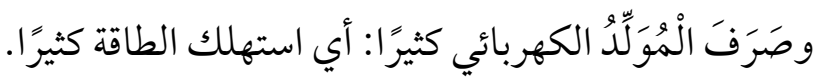

$$
\text { وصرف عنه النظر، بمعنى: لم يكترث به. }
$$

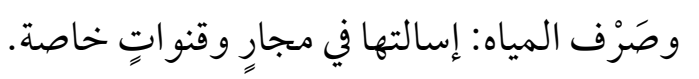

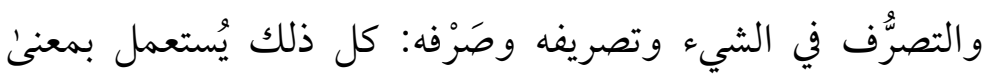

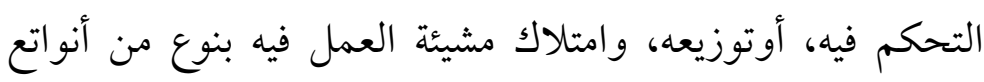




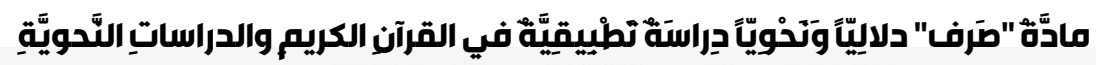

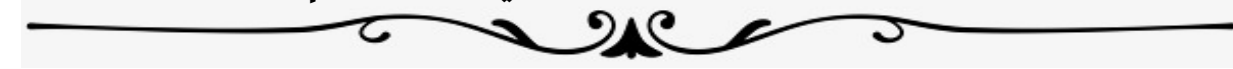

$$
\text { التغيير ونحوه(1). }
$$

وهذا الذي ذكرته ما هو إلا أمثلة يسيرة، لتطور استعمالات كلمة "صرف" في

العصر الحديث، والحق أن إحصاءَ دلالاتها فيه ومجالات استعمالها يستعصي على العادّ، وهذا التطور مستمر إلى يومنا هذا، مثل:

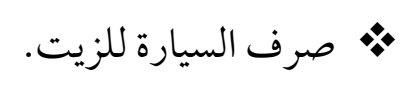

$$
\text { * و والمصارف المالية(واحدها: مَصْرِف) وهي البنوك. }
$$$$
\text { وصرْف الفواتير. }
$$

وتصريف شؤون البلد.... ومن أراد الاستزادة فعليه بالمراجع

المحال إليها.

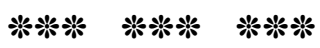

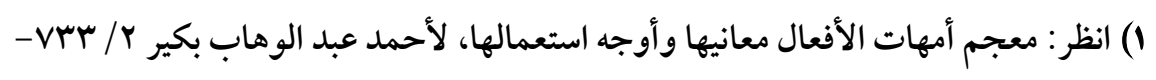

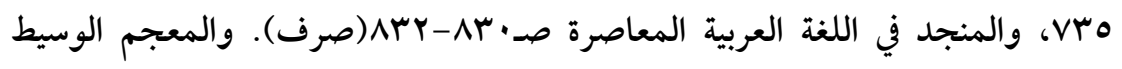

$$
\text { صrr| (صرف). (ص) }
$$




\section{مجلة كلية اللغة العربية بالمنوفية العدد الخامس والثلاثون - إصدار ديسمبر 2020م

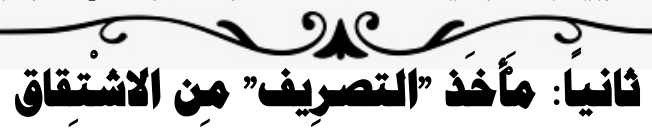

كلمة "التصريف" مشتقة من "صَرَّف" المضعَف العَين، واستقصاء دلالة هذه هَه المادة يقتضي معرفة العلاقة اللغوية بينها وبين الاشتقاق، ويَتبيَّن مما سبق في التأصيل المعجمي التداخلُ الدلاليُّ والإجرائي بين "التصْرِيف" لغةً والاشتقاق، وستِ ومِنْ ثَمَّ عُدَّ التصريف من أدلَّة الاشتقاق(1)، فالاشتقاق مأخوذ من "الشّقّ" وأصله

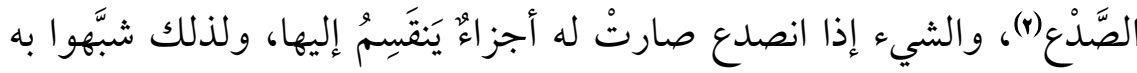
تشقيق اللفظ إلى ألفاظ متباينة، ولكنها ترجع إلى أصل واحدٍ، تدلّ عليه كلها

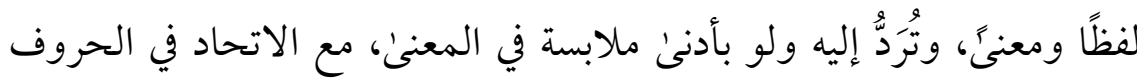

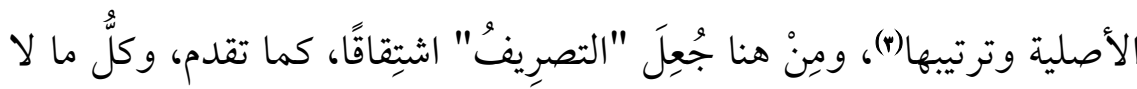

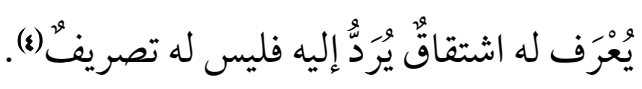

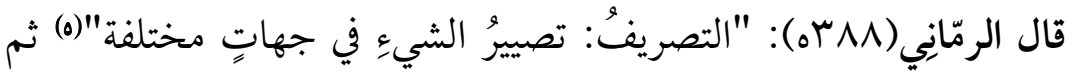
قال:"الاشتقاق فُعُ مِن أصْلٍ يدورُ في تصاريفه على الأصل "(૧) وبيانُ كلامِه أنّ الجهات المختلفة التي يُصارُ إليها في التصريف، هي الفروع المشتقة من الأصل

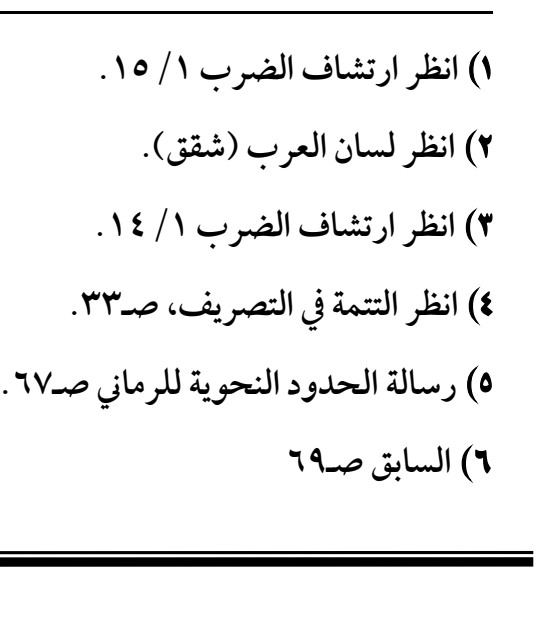




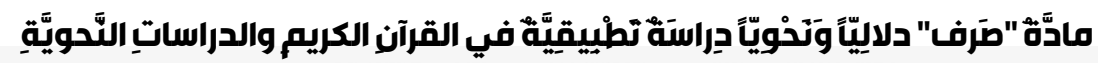

المتصرِّف، ولو لا أنّ المادة اللغوية قابلةُ لتصييرها في جهات مختلفة لَّما أمكنَ الاشتقاقُ منها.

وقال ابن جني(rوسهـ) : "وينبخي أنْ يُعْلَم أن بين التصريف والاشتقاق

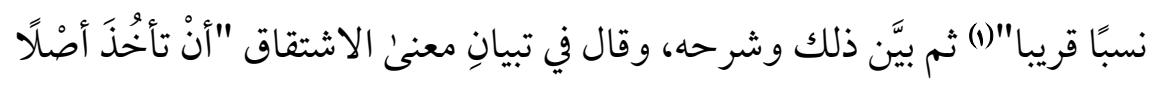
من الأصول فتتقوَّاهُ فتجمَعَ بين معانيه، ورإنْ اختَفَتْت صِيَغَهُ ومَبَانيه"((r) قوله:

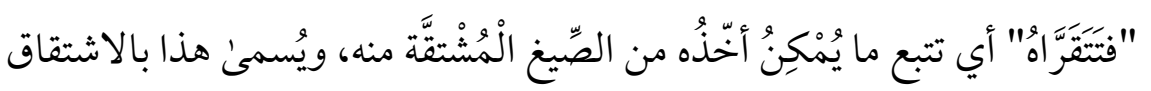

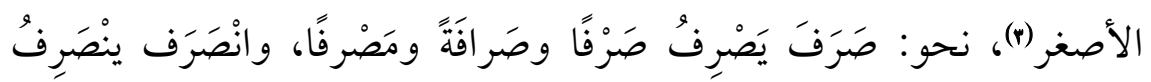

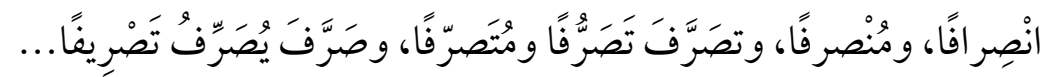
قال صاحب مراقي السعود:

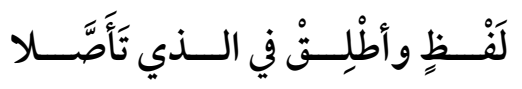

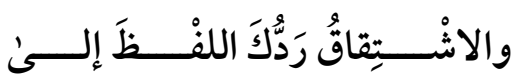

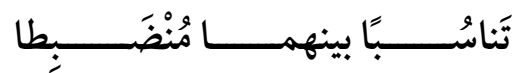
وفي المعــاني والأصـــولِ اشــتِر اطا

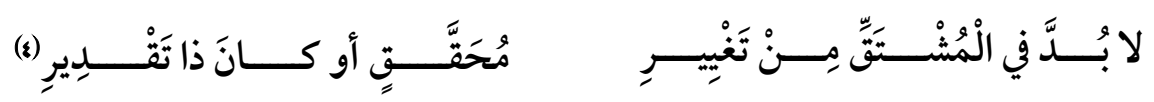
معنى هذا أنّ الاشتقاق الذي ذكره ابن جني في تعريفه السابق حقيقته: تفريع اللفظ الو احد إلىن ألفاظٍ، تحكمُ على أحدها بأنه الأصل، ثم تحكم على سائرها بأنها فروع عنه مردودة إليه، بثلاثة شروط:

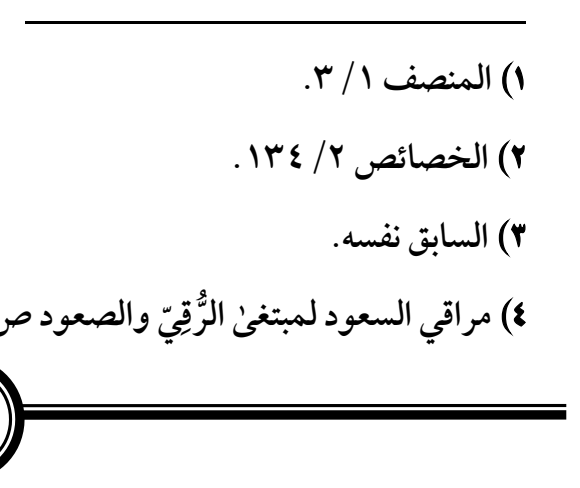


الأول: أن يكون المعنى الأصلي الذي يدل عليه الأصلُ موجودًا في فروعه، ويُسمَّى هذا بالتناسُب المعنويّ.

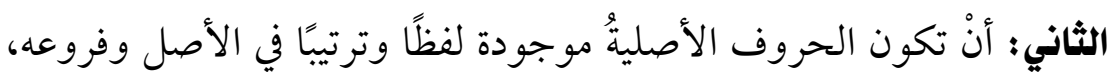

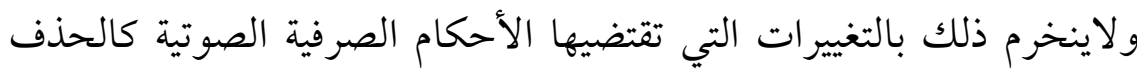

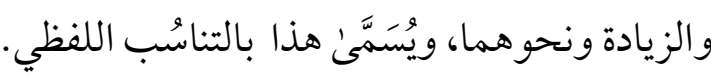

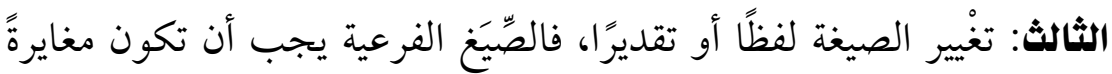

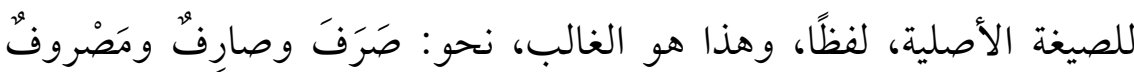

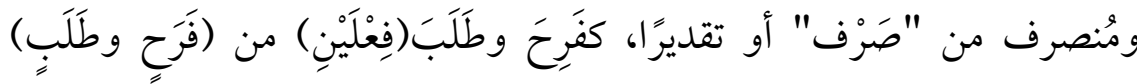

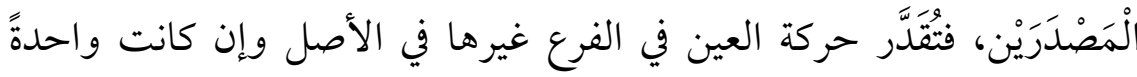

صؤتًا. (1)

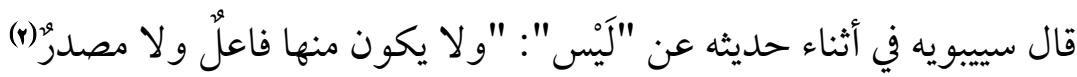

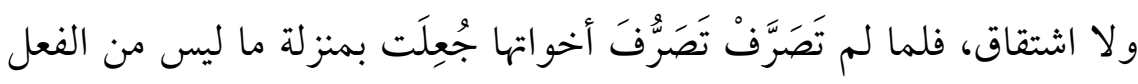

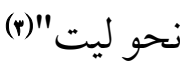

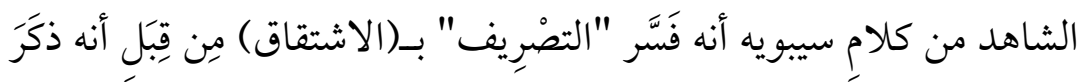

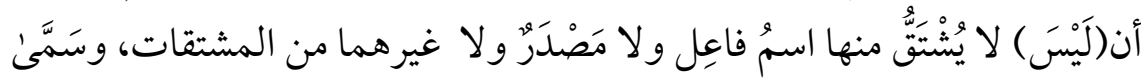

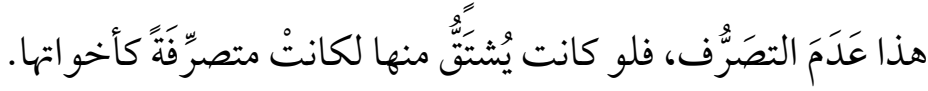

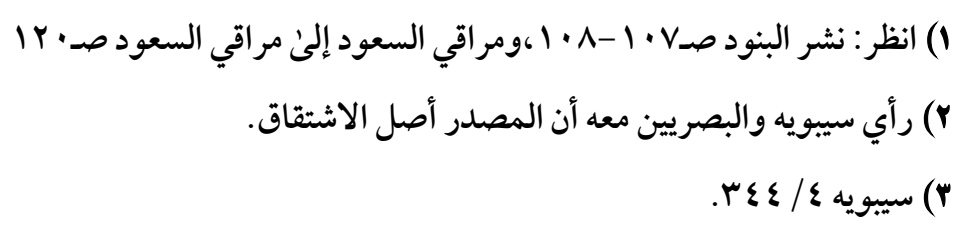




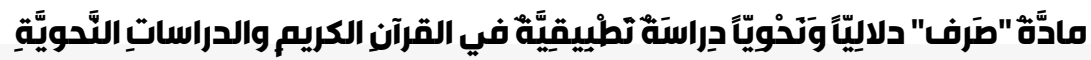

وقال أيضًا:"هذا باب ما تُكثُُّّ فيه المصدرَ من فَعَلْتُ، فُتُحقُ الزوائدَ وتَبْنيه

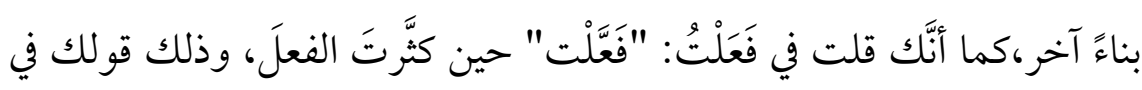

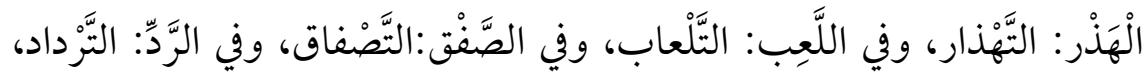

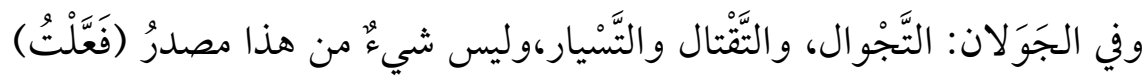

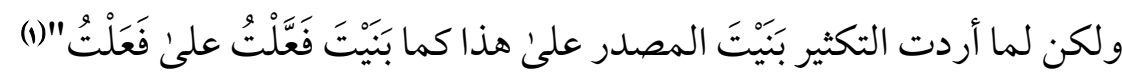

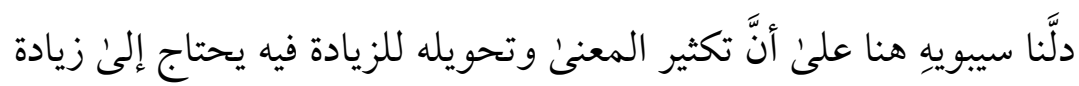
في المبنى، أي التفريع على الأصل ـ وهذا هو مفهوم الاشتقاق ـ فإذا أردنا الدلالة على كثرة الفعل من "صَرَف" قلنا: "صَرَّف" وإذا أردنا المبالغة في تكثير مصدره قلنا: "التَّصْر اف" بدل التصريف، وهذا يعنى أن اشتقاق صيغة من أخرىن يلزم منه قلبُها وتحويلها إلى صورٍ تصريفية مغايرة لأجل المعنى المراد ــوهذا

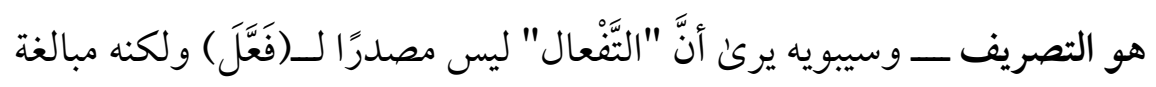

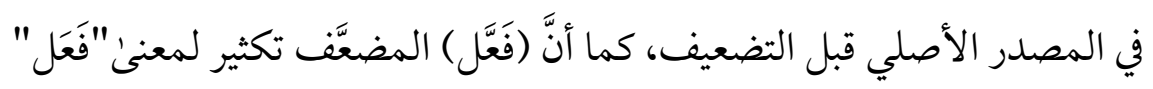

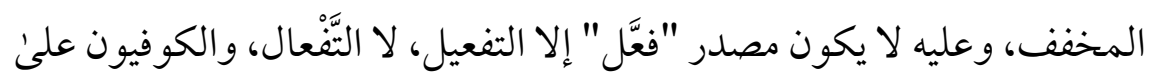
خلافه في ذلك(r). والخلاصة أن الدلالة المعجمية الأصليةً لمادة "صرف" تتحقق تحققًّا بِينّاً في ظاهرةِ الاشتقاق في اللغة، ولذلك قال ابن جني: "ولا يوصَل إلى معرفة الاشتقاق إلا به(r)، وقد يؤخذ جزءٌ من اللغة كبير بالقياس، ولا يو صَل إلى ذلك

$$
\text { ) سيبويه \&/ / }
$$

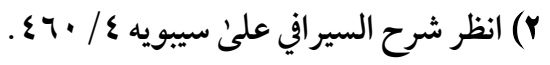
r) أيْ : التصريف. 
إلا من طريق التصريف" (1) ذلك لِما يستلزمه الاشتقاق من تقليبات وتغييرات في

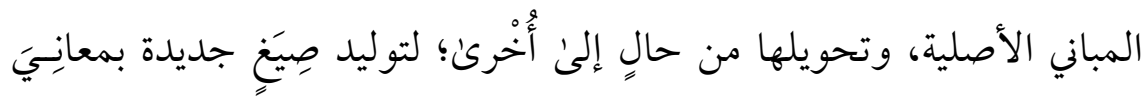

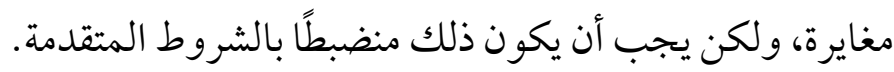

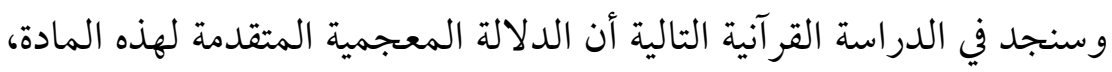

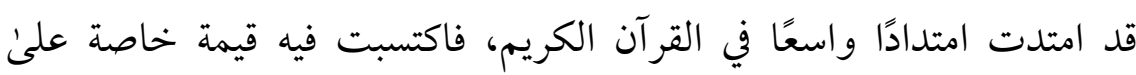

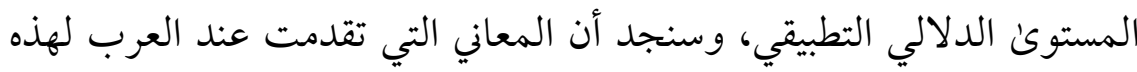

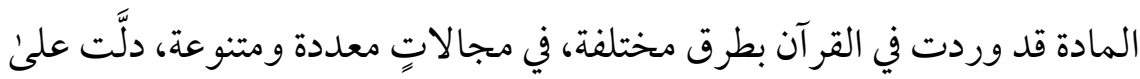

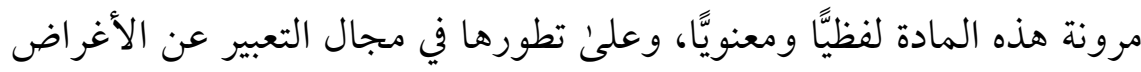

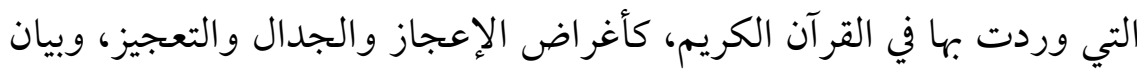

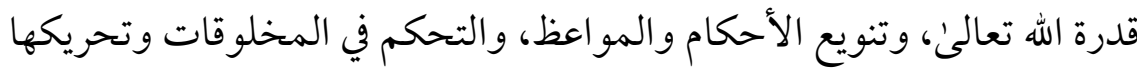

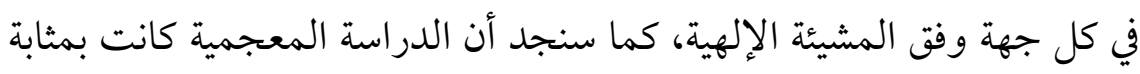
التمهيد لفهم هذه المعاني التي نجدها في القر آن لهذه المادة.

楼楼楼楼

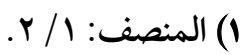




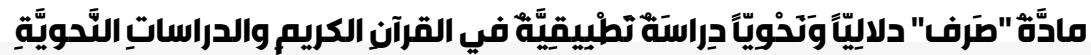

\section{ore}

ثالثاً: صِيخُ(صرف) المستعمطة في القرآن الكريم

\section{ودلالاتها السياقية المنية}

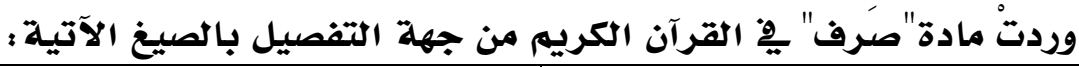

\begin{tabular}{|c|c|}
\hline rاِـَعَلَ: صَرَفَ. & ا- فَعْل :صَرْف. \\
\hline عــانْفَعَل : انْصَرَف. & "َـــفعِلَ: صُرِفَ. \\
\hline T- يُفْعَلُ : يُصْرَفُُ. & هـ- يَفْعِل: يَصْرِفُ. \\
\hline ^_ـَعَََّ: صَرَّف. & V_ افْعِلْ : اصْرِفْ \\
\hline •ا ـ تَفْعِيل: تَصْرِيف. & q-ـيَفَعَّل: يُصَرِّف \\
\hline r ا ـــمَفْعِل: مَصْرِف. & 11 - مَفْعول: مَصْرُوف \\
\hline
\end{tabular}

رتبّتُها ابتداءً بالمصدر من مخفف العَيْن لكونه مادة الاشتقاق، وهو مادة الدراسة من جهة العموم، ثم أوْليته الصيغ الفعلية من مخفَّف العَين؛لأجل التقارب الشديد بين دلالاتها، ثم أعقبتُها بالصيغ الفعلية من مضعَّف العَين؛ للسبب نفسه - وهو التقارب الشديد بين دلالاتها، وثلَّثتُ بالصيخ الاسمية لكونها في التصريف والاشتقاق تابعةً للفعل، فهذه ستة صنوفٍ لهذه الصيخ: المصدر المجرد، والفعل المخفف العين، والفعل المضعّف العين، ومصدر مضعَّف العَين، واسم المفعول، واسم المكان، روعي في تصنيفها العام الجانب التصريفي، وفي ترتيبها وتصنيفها الداخلي الجانب الدلالي، وهما متداخلان. وهي في جميع هذه التصاريف تَرْجع في معانيها إلى الدلالة الجذرية المتقدمة، ولكنها استُعمِلت في كل مرة في اشتقاق يقتضي بعض تلك المعاني، وقد تحمل أحيانًا تطويرًا للدلالة وإمدادًا لها ببعض الأبعاد الملابسة لها، وتوسيعًا لمفهو مها بهائ الأصلي، بما يقرب منه حقيقة أو مجازًا أو استعارةً؛ لأجل الأغراض السياقية 


\section{مجلة كلية اللغة العربية بالمنوفية العدد الذامس والثلاثون - إصدار ديسمبر 2020م}

\section{ग्र}

للنص الذي وردتْ فيه، وسيتبين ذلك في دراستها التالية وفْق هذا التقسيم

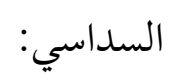

\section{اـ "صَرف" بصيفة مصدر الثلاثي المجرده:}

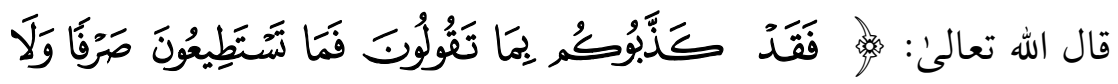

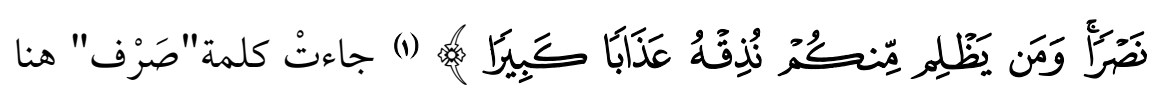
دالةً علىن المعنى الأصلي لها وهو الرّدّ والقلب، أي: ما تستطيعون ردَّا ولا قلبًا للتكذيب، ولا لجزائه وهو العذاب، ومحتملة لمعنى : الاحتيال والتصرّف، والتوبة(r)؛ لأن السياق يرشح لها كل ذلك في هذا الموضع، فيكون المراد: لا

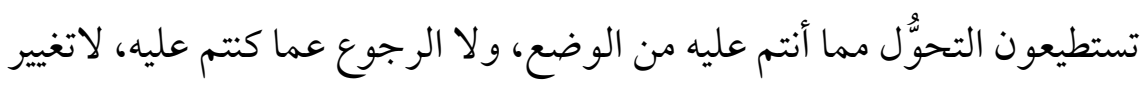

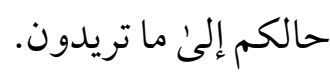

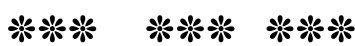

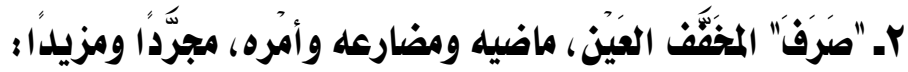

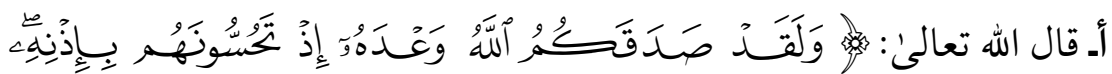

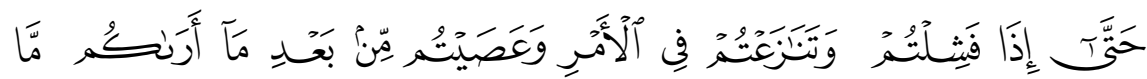

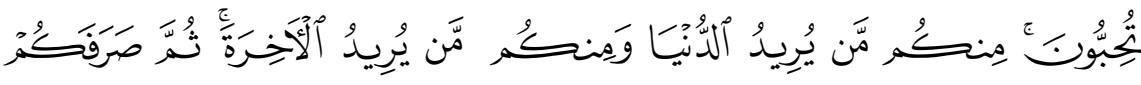

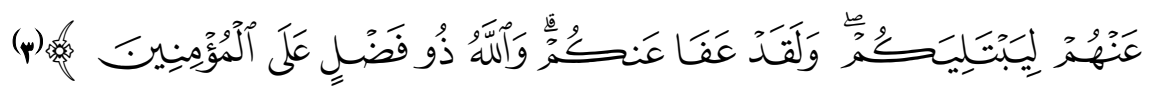

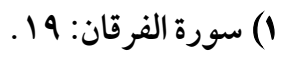

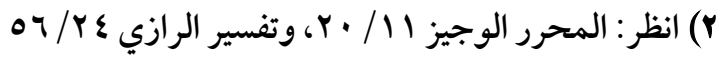

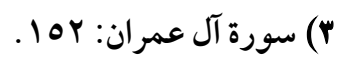




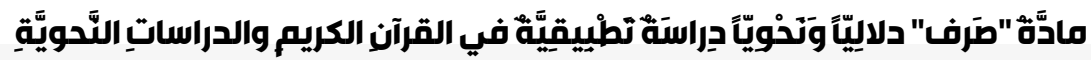

\section{ac}

أوْردْتُ الآيةَ كاملَةً ليتبين السياق الذي وردت فيه الكلمة، ومناسبة ما قبلها لما بعدها، والمعنى: ردّكم عنهم فتحوّلتم عن قتالهم إلى غيرهم(1)، وهذه هي الدلالة الأصلية لمادة(صرف) ولا يخفىن ما يدل عليه الصَّرْف هنا سياقيّا من

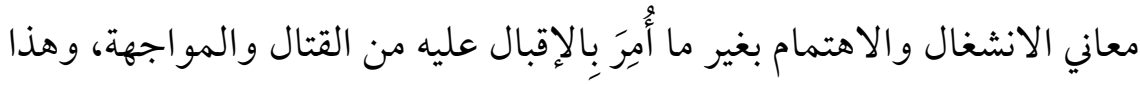
استعمالٌ مجازيٌّ متفرع عن المعنى الأصلي.

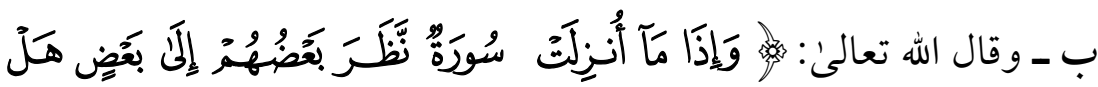

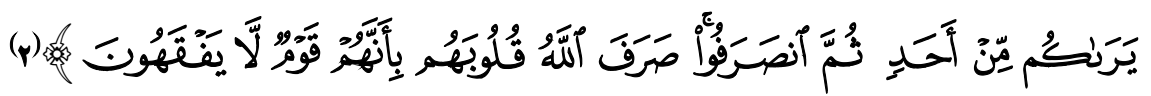

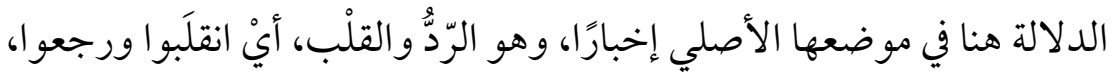
ثم أخبر الله أنه فعلَ بهم ذلك مجازاةً لهم على أفعالهم، ويُحتمَل أن يكون المراد الدعاء عليهم (()، أي جعَلَ الله قلوبهم مصروفةً عن الحقِّ، علن سبيل الدعاء عليهم، فدلالة الدعاء هذه دلالة سياقية مجازية من جهة الأسلوب، والمعنى

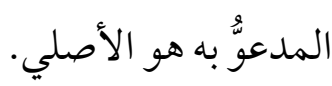
وقد بسط الطبري(•اسهـ) ذلك فقال: "يقول تعالى ذكره: وإذا ما أنزلت سورة من القرآن فيها عيب هؤلاء المنافقين الذين وصف جل ثناؤه صفتهم في هذه السورة وهو عند رسول الله صلى الله عليه وسلم نظر بعضهم إلى بعض فتناظروا هل ير اكم من أحد إن تكلمتم أو تناجيتم بمعايب القوم يخبرهم به؟ ثم قاموا فانصرفوا من عند رسول الله صلى الله عليه وسلم، ولم يستمعوا قراءة

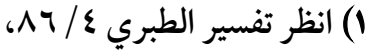

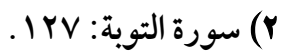

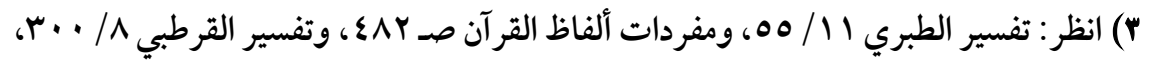




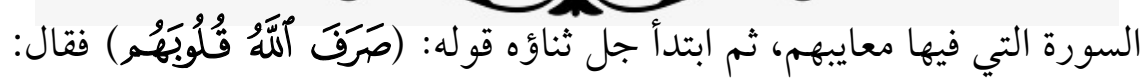
صرف الله عن الخير والتوفيق والإيمان بالله ورسوله قلوب هؤلاء المنافقين؛

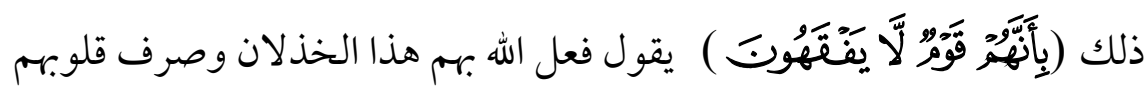
عن الخيرات من أجل أنهم قوم لا يفقهون عن الله مو اعظه استكبارًا ونفاقًا"(1)

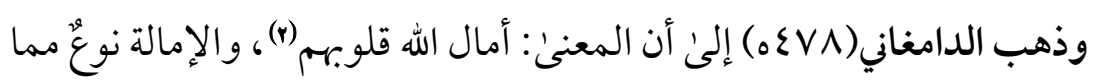

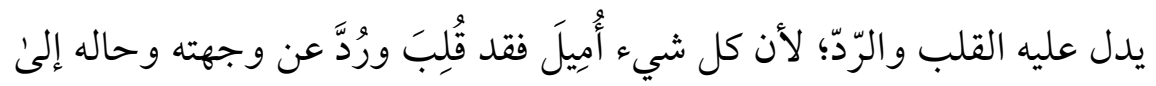
غيرها، سو اء أكان ذلك على سبيل الإخبار أو الدعاء. ج - قال تعالى:

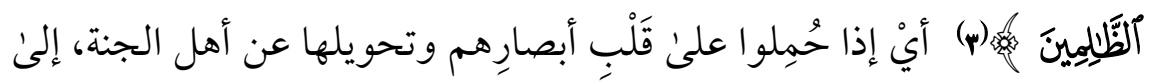

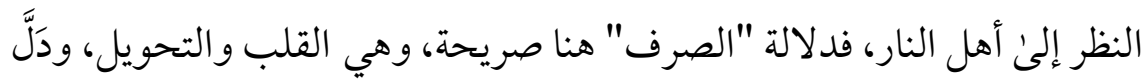
بناء الفعل للمجهول على أنهم حُمِلو إعلى ذلك إمَّا مُكْرَهين لأجل أن يتعظوا ويحمدوا ربهم (8)، أو أنّ ذلك حصل منهم مما جُبِل عليه الإنسان من حبِّ

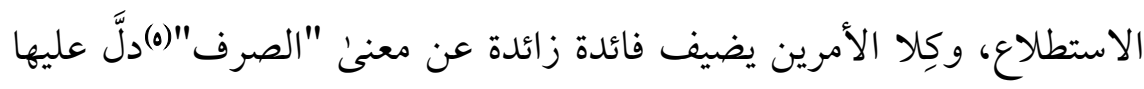
السياق، قال ابن عاشور(بهوباه) رحمه الله: "والصرف هنا مجازٌ في الالتفاتِ أو استعارة"(ج) وإنما حمله على هذا أنه قال قبله:"الصرف: أمر الحالّ بمغادرة

$$
\begin{aligned}
& \text { 1) تفسير الطبري 11/ } 11.00 .
\end{aligned}
$$

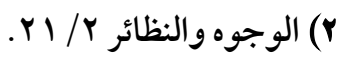

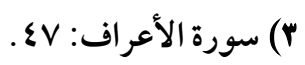

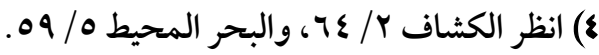

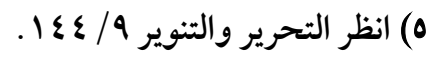$$
\text { 1) السابق نفسه. }
$$ 


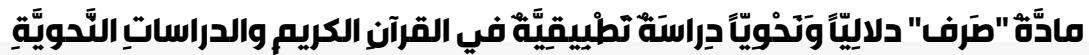

\section{ose}

المكان"(1) فهو يركن أن الأبصار لم يكن منها مغادرة لمكانها، وإنما استعير لها ذلك تشبيها، أو استُعمل الالتفات مجازًا في المغادرة!

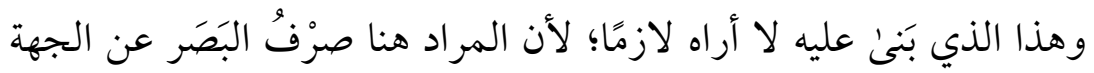

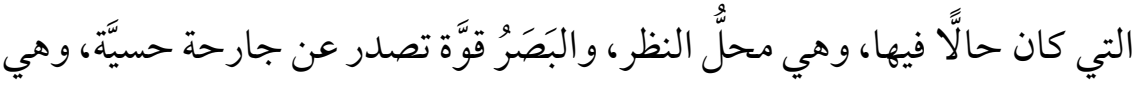
العين، فتدرك بها الأشياء الحسية كالألوان والأشكال والأضواء(()، ولذلك يُعلُّ

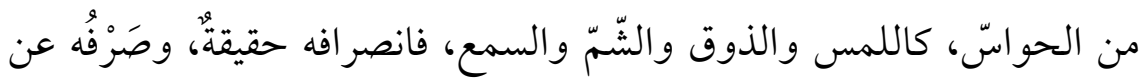

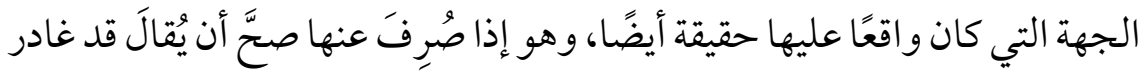

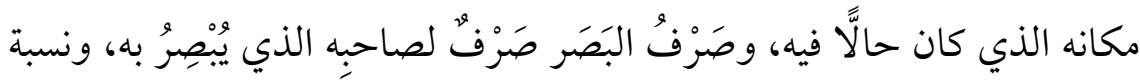
الفعل لعضو من أعضاء الفاعل نسبة حقيقية إلى الفاعل، لأنها جزء منه، ولايُّسَب

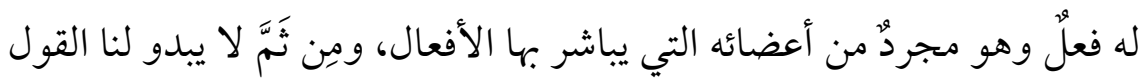

$$
\text { بالمجاز أو الاستعارة هنا لازِمًا. }
$$

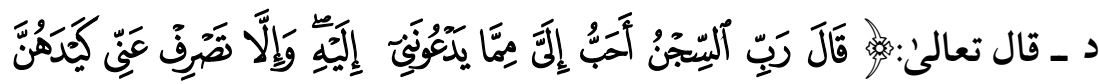

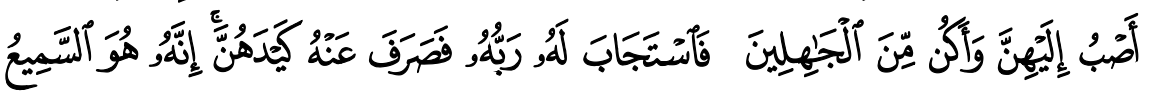

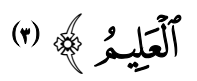

وفي هاتين الآيتين ورد الصرف بمعنى الدفع (8) والمنع والحماية، لأن السياق على هذا يدل، فيوسف عليه السلام طلب من ربه أن يدفع عنه كيد النساء ويحميه

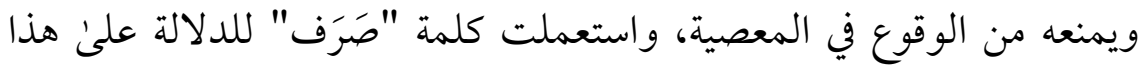

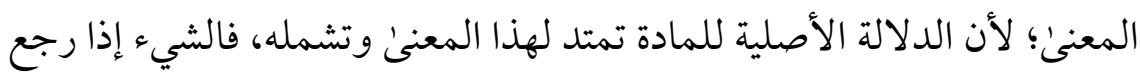

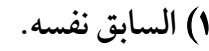

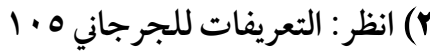

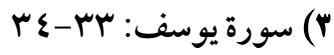

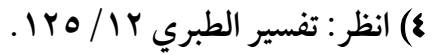




\section{مجلة كلية اللغة العربية بالمنوفية العدد الخامس والثلاثون - إصدار ديسمبر 2020م}

2 (e)

عنك وقُلِب إلى وجهةٍ غير وجهتك فقد دُفِِعَ عنك ومُنعِتَ منه، غير أن التعبير

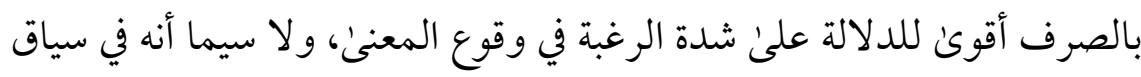

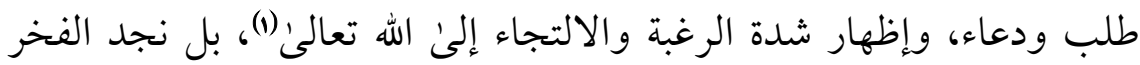

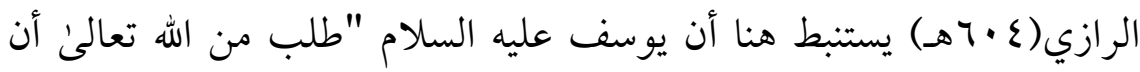

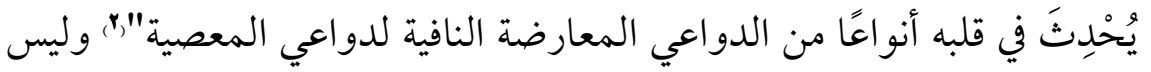

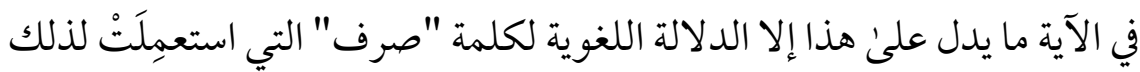
هنا لِسعَة دلالتها، فهو امتدادُّ مجازيّ.

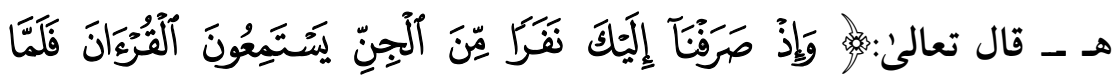

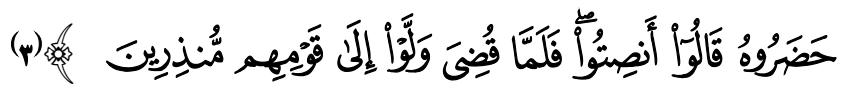

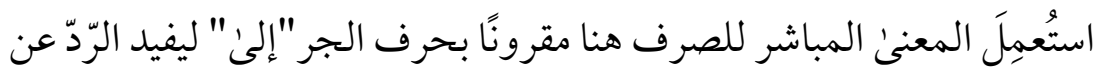

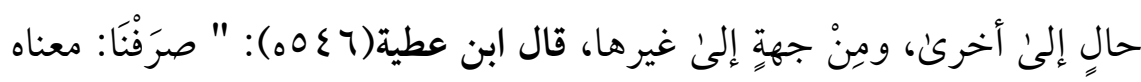

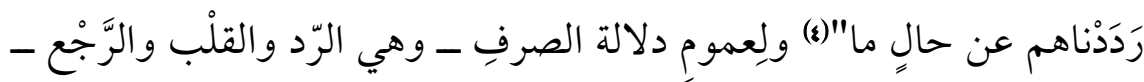

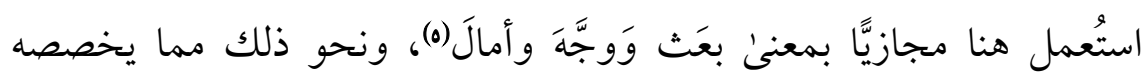

1) انظر حول هذه الدلالة الموضع السابق من تفسير الطبري، والتحرير والتنوير لابن

$$
\begin{aligned}
& \text { عاشور r / דrr. }
\end{aligned}
$$

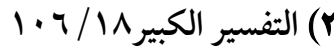

$$
\begin{aligned}
& \text { r) سورة الأحقاف: } 9 \text { r }
\end{aligned}
$$

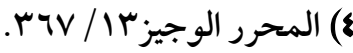

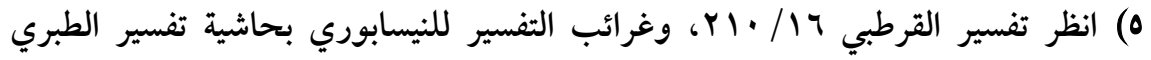

$$
r \cdot r y
$$




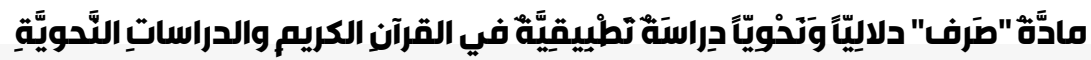

\section{ace}

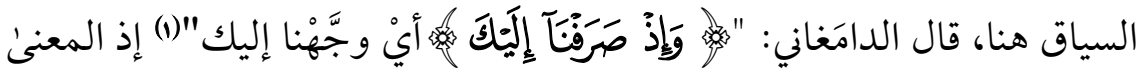
أن الله تعالئ وجَّةَ مجموعة من الجنِّ وبَعَثَهم إلى الرسول صلئ الله عليه وسلم

ليستمعوا منه القرآن(r) (ب) (ب)

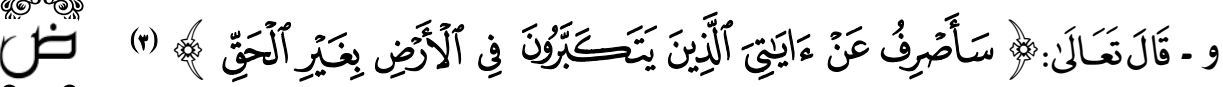

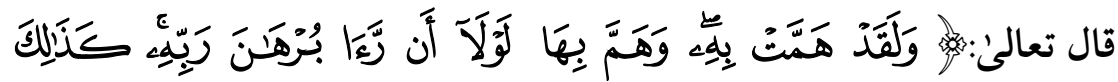

\section{(ع)}

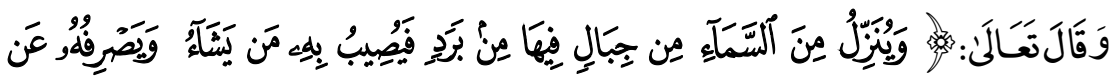

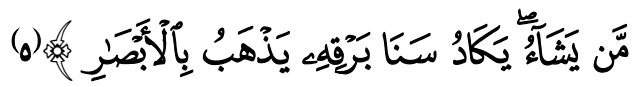
جاء "الصرف" في هذه الآيات بصيغة المضارع الدال على الحال والاستقبال، والاستمر ار والتجدد، والمعاني العامة المجازية التي تحملها هذه الصيغة في هذه

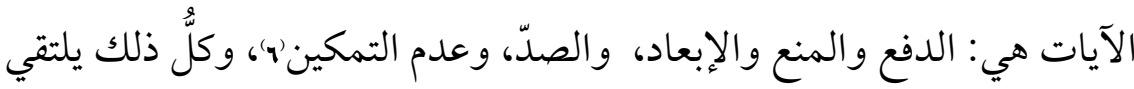

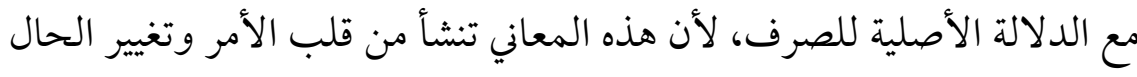

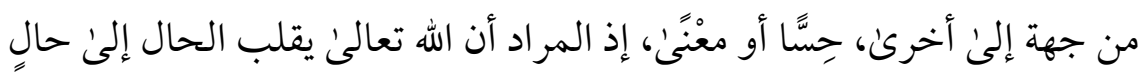

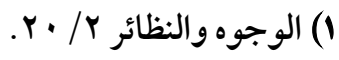

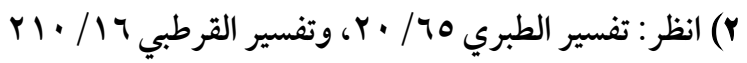

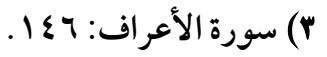

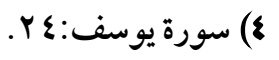

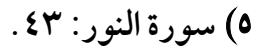

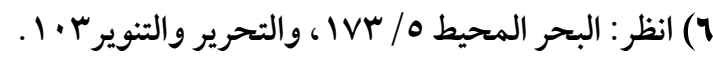




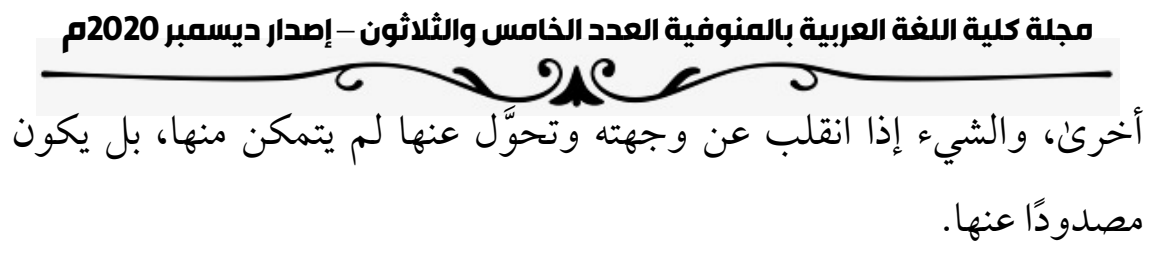

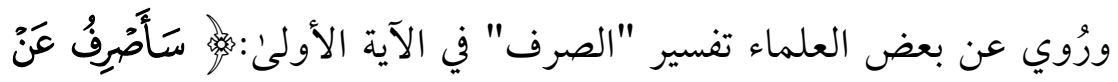

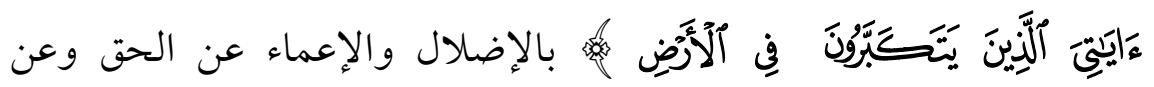

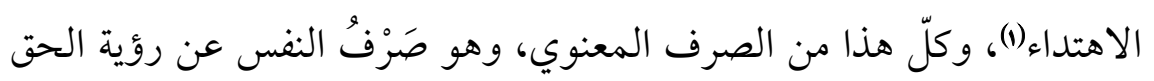

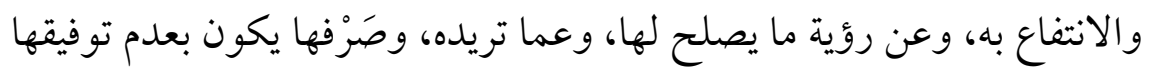

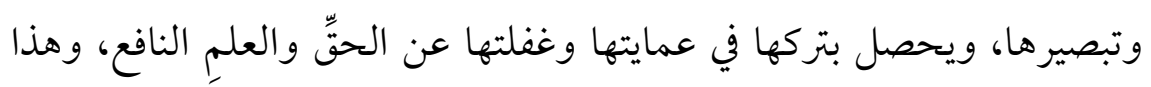
امتدادُّ مجازي للدلالة الأصلية للصرف.

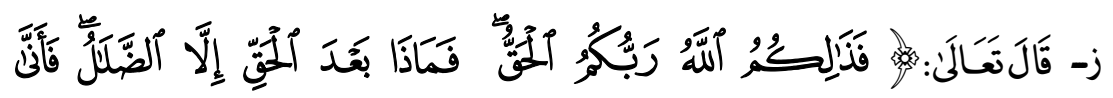

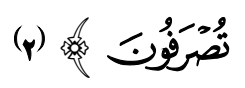

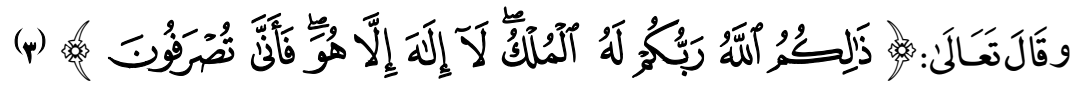

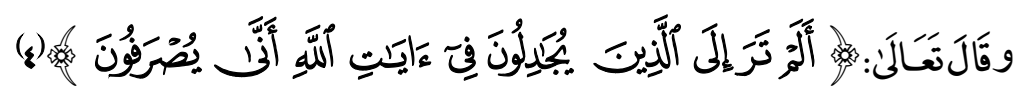

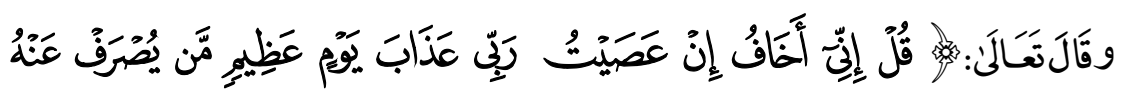

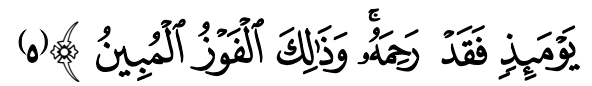

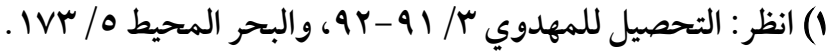

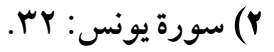

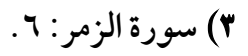

$$
\begin{aligned}
& \text { §) سورة غافر: } 79 . \\
& \text { 0) سورة الأنعام: } 10 \text {-17. }
\end{aligned}
$$




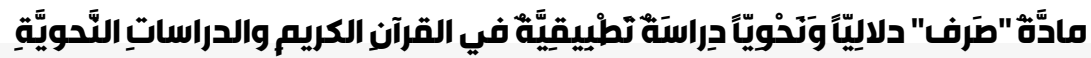

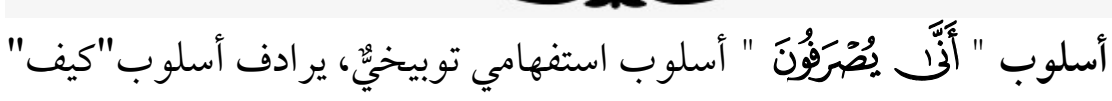

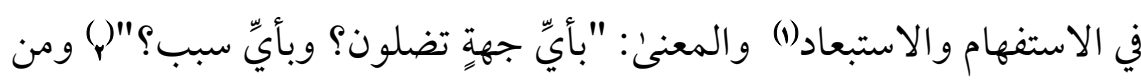

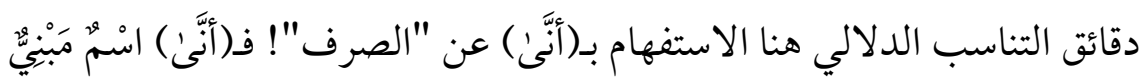

للاستفهام عن مكان وجهةٍة، بمعنى "كيف" على وجه الاستبعاد، نحو: أنّئ يكون

هذا؟ أي: كيف يكون؟ وقد ترادف (أينما) نحو: "أنّى ذهبت تجد الشمس

والقمر" أي: أينما ذهبت(م)، فهو مناسبُ للصرف الذي هو الانصراف من جهة

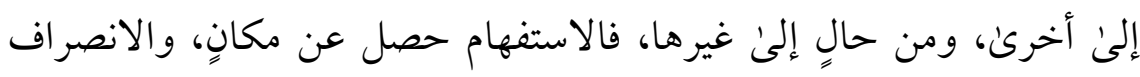
واقع من مكان إلى آخر، فوقع التناسب الدلالي بينهما، وهذا من دقائق الأسلوب القرآني الرائع، ومن دقائق الاستعمالات المجازية لهذه المادة.

و"الصرْف" في هذه الآيات مثله في الآيات اللاتي قبلهنّ، جاء بمعنى الدفع

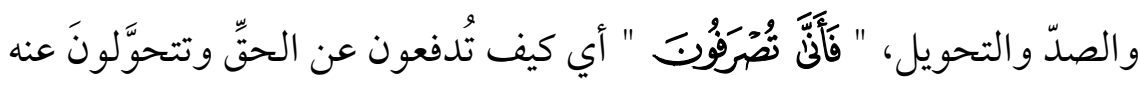

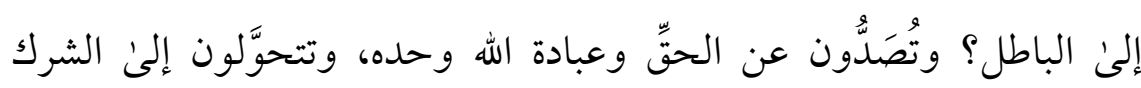
باستمراركم عليه، أو تعدلون عن الإيمان إلى الكفر(8)، وبهذا يرتبط المعنى

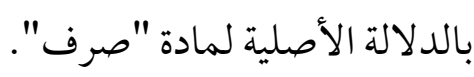

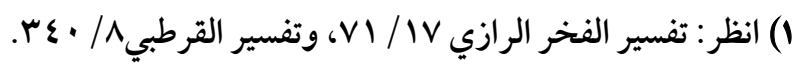

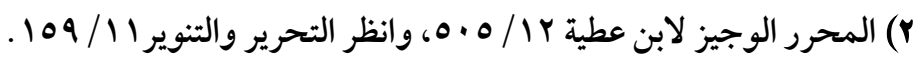

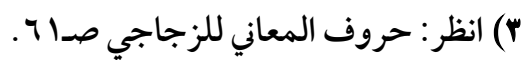

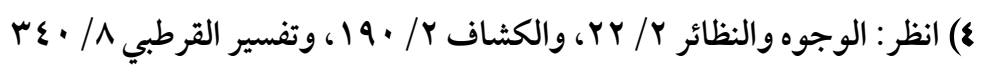




\section{مجلة كلية اللغة العربية بالمنوفية العدد الذامس والثلاثون - إصدار ديسمبر 2020م}

وقول الله تعالىي:" مَّن يُصْرَفْ عَنُُْ " أَي مَنْ ينجيه الله ويحفظه من العذاب

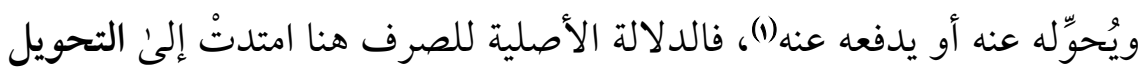

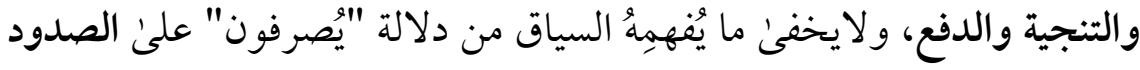

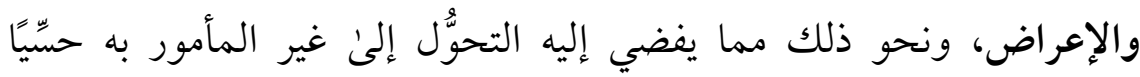
ومعنويًا، أو الإعراض عن أسباب السعادة إلى أسباب الشقاوةِ. ولا يخفى أيضا ما يدل عليه بناء الفعل للمجهول في هذه القراءة، في الكلمات المسندة لو او الجماعة، من كون الصرف ناتجًا عن هوئ النفس وتكذيبها للحق،

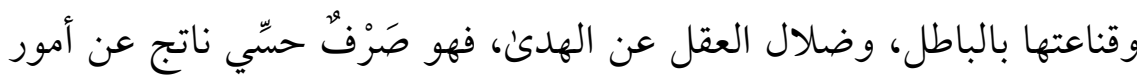

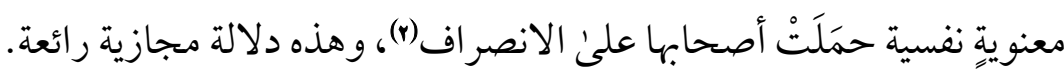

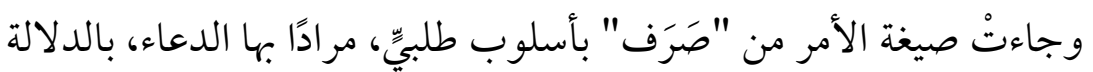
المتقدمة نفسها، في قول الله تعالىي:

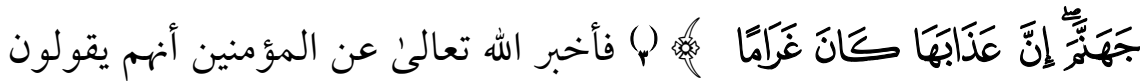

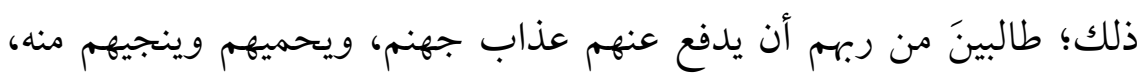
وجاءت دلالة كلمة " اصْرِفْ" هنا مناسبة للسياق الذي سيقت له، وهو بيان شدة فَرَقهم من عذاب جهنم، وعظيم خوفهم منه ()؛ لِمَّا تدل عليه هذه المادة اللغوية

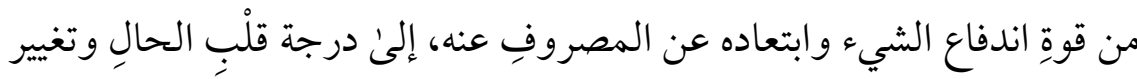

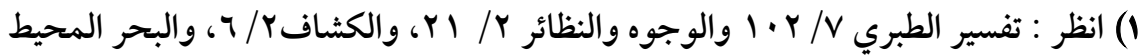
.$\{00 / \varepsilon$

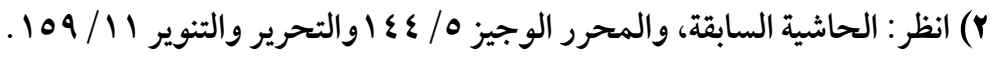

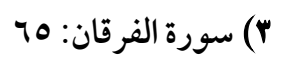

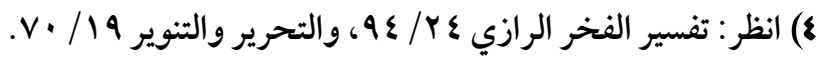




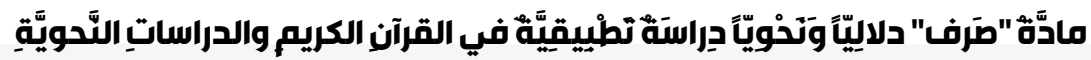

\section{VC}

الوضع القائم أو الْمَخوف إلىن عكسه، فانظر كيف حصل الربط العجيب بين الدلالة الأصلية لــ(صرف) وهذه المعاني المجازية الناشئة!

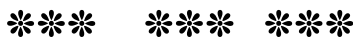

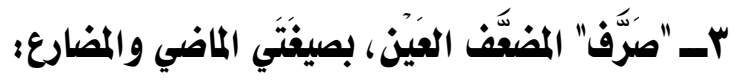

تقدَّم في تأصيل الدلالة المعجمية أن "صرّف" المضعَّف العين يدل على زيادةٍ في المعنى(1)، قد تكون تلك الزيادة لغرض التأكيد أو المبالغة، أو التعبير عن تكرار إيقاع الفعل وتنويعه، ونحو ذلك من المعاني المجازية، مهما يكن المعنى السياقي المخصص للدلالة الأصلية، وسيتبين ذلك في الآيات الآتية:

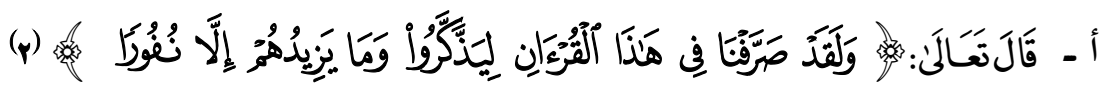
معنى الصرف هنا: التبيين، أيْ بيَّنَّام) قال الفخر الرازي رحمه الله :"قال الجبّائي:

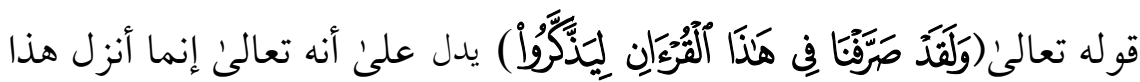
القرآن، وإنما أكثر فيه من ذكر الدلائل لأنه تعالى أراد منهم فهمها والإيمان بها..."() فذكر أنَّ "صرَّف" هنا يدل علىن تكثير التبيين لغرض الإفهام والدعوة للإيمان، ومنشأ التكثير أن "التصريف" يقتضي التكرير والتنويع(ه)، وهذا تفريع مجازي مستفاد من الصيغة.

1) انظر المغني في تصريف الأفعال للشيخ عضيمة، صاسبا .

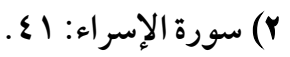

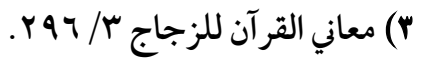

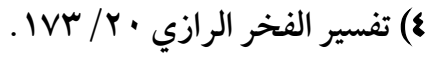

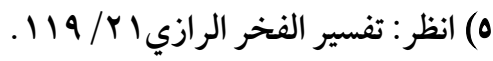




\section{مجلة كلية اللغة العربية بالمنوفية العدد الذامس والثلاثون - إصدار ديسمبر 2020م}

\section{C}

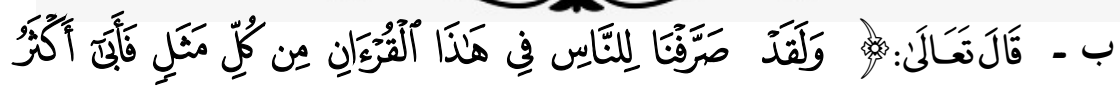

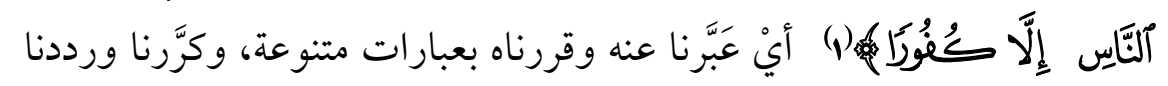

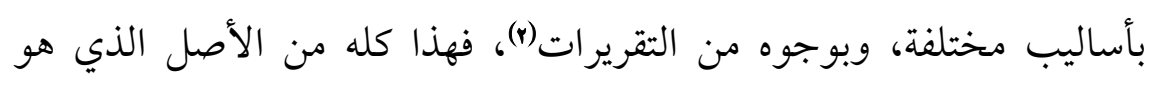
تحويل الشيء وتنويعه من حالٍ إلى حالٍ، واله يخبرنا عن تصريفه للأمثال

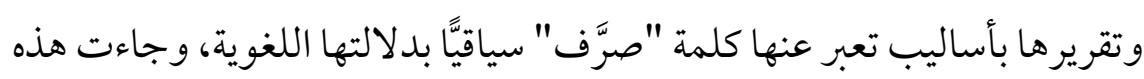
الدلالَةُ بالطريقة نفسها في الآية التالية:

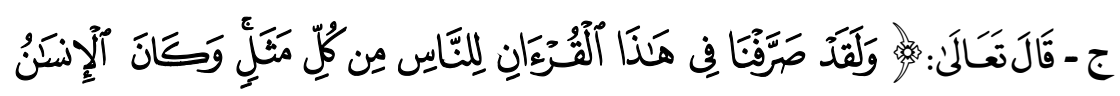

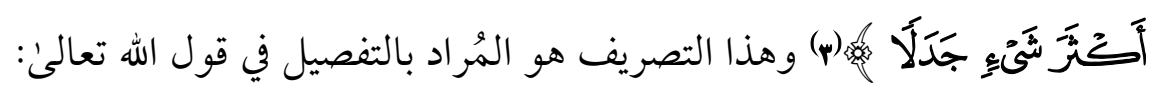

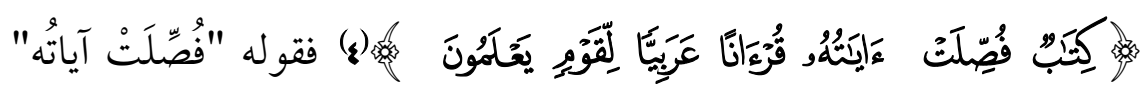

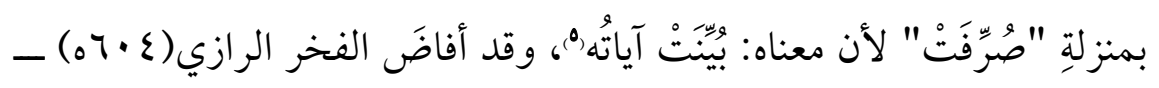

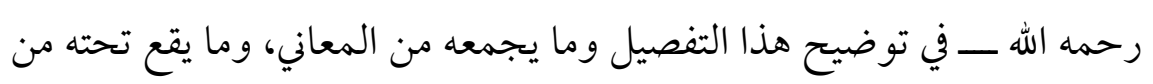

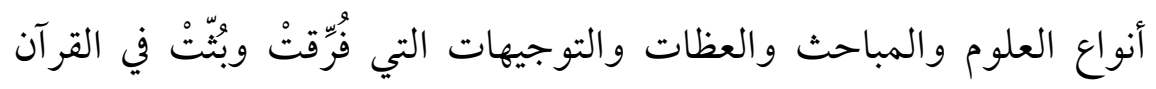

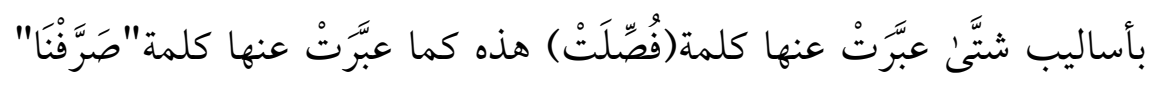

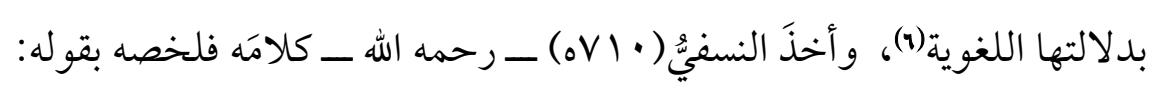
1) سورة الإسراء: 19.

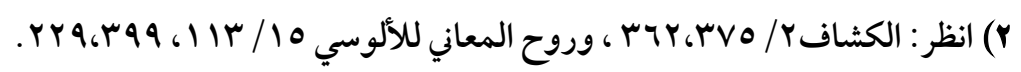

$$
\begin{aligned}
& \text { ץ) سورة الكهف: ؟ه. } \\
& \text { §) سورة فُصِّلَت م. س. } \\
& \text { 0) تفسير الطبري } 11 \text { / } 09 .
\end{aligned}
$$

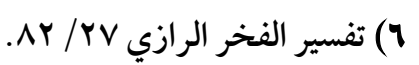




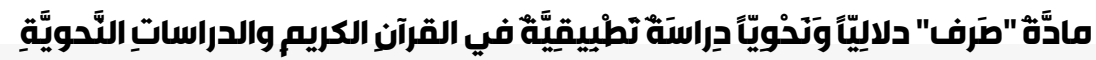

\section{$\longrightarrow$ Casc}

"(فُصِّلَتْ آياتُه) مُيِّْتْ وجُعِلَتْ تفاصيلَ في معانٍ مختلفة، من أحكامِ وأمثالِ، ومواعظَ، وَوعٍِ ووِِيدٍ، وغير ذلك"(1) وهذا الذي ذكره الامتدادات المجازية

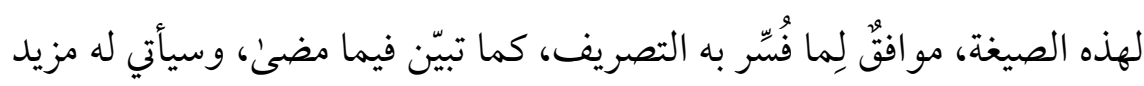
من التبيان.

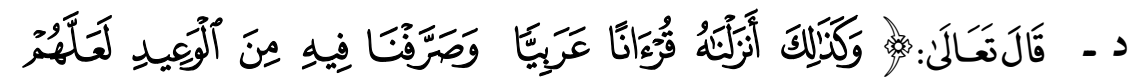

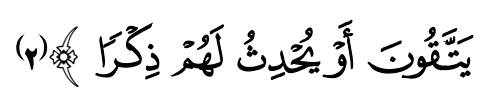

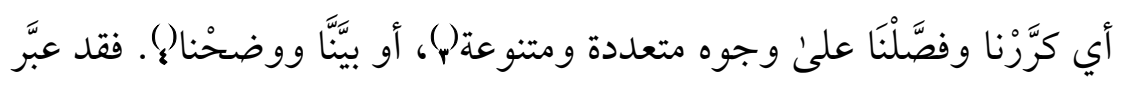

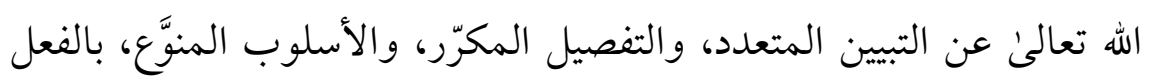
"صَرَّف" المفيد لتغيير الحال، وقلب الشيء إلى جهاتٍ متعددة، ليدل بهذا المعنى المعجمي على جميع هذه الأغراض السياقية بما يتضح بها من المعاني

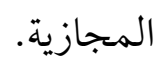

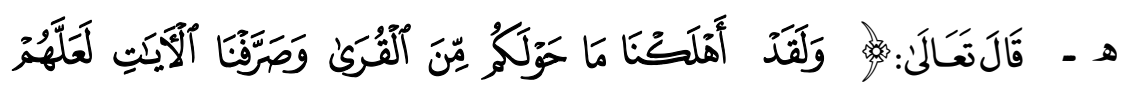

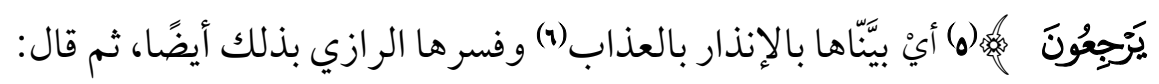

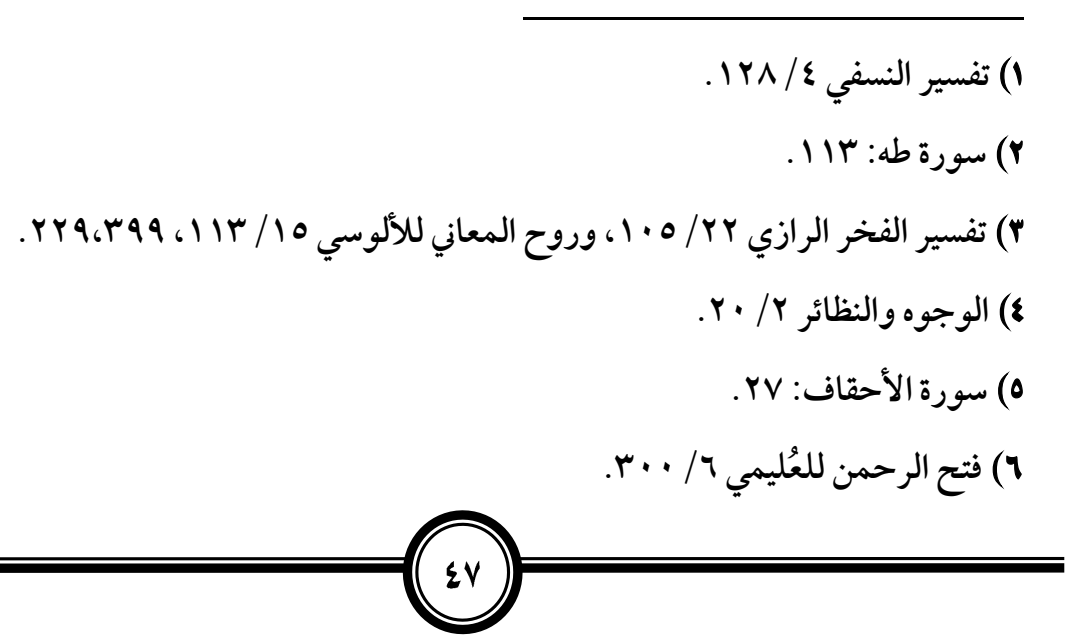


"المراد بالتصريف الأحوال الهائلة التي وُجِدتْ قبل الإهلاك" "() وقيل: كرَّرنا عليهم الحُجج وأنواع العِبَرَ ()، فدل الفعل "صَرَّف" على زيادةٍ في التبيين، والتنويع في الحُجج والمواعظ، وقلْب الأمر ورجْعِه من حالٍ إلى حالِّ، وهذا الغرض لا يفيده في مثل هذا سوكن لفظ "التصريف" لشموله لأنواع التغيير و التبديل والتنويع، وهذه كلها تفريعات من الدلالة الأصلية، كما تقدم.

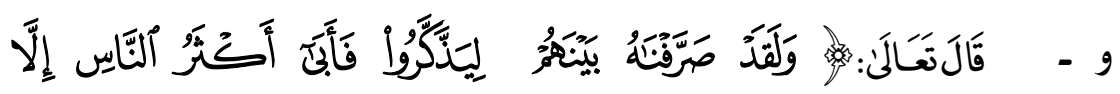

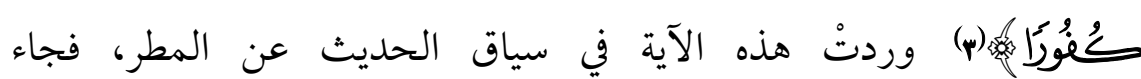
معنى "صرَّف" بمعنى : قَسَّمَ، أي قسَمْنا المطر بينهم ليتعظوالاُ، وعبَّ بعض العلماء عن "التصريف" هنا بالتنويع والتكرار والتوزيع والإجراء في جهات مختلفة، وأزمان متنوعة، ودرجات متفاوتة، سواء أكان المراد المطر أو غيره(ه)، وهذا متجه؛ لأن عموم الدلالة في الفعل"صرَّف" يمتد لذلك كله، والسياق يخصص عمومه بهذه المعاني المجازية الاستعمالية. وهكذا قد تَبيَّن لنا من خلال هذه الآيات أن الدلالة الأصلية لمادة "صرف" لِّل قد تجددت لها زيادة في التنويع والتكرير والمبالغة، في صيغتها المضعَّفة، لأغراض متعددة كإرادة مزيد من البيان والتوضيح والتفهيم، أوالتبيه والتحذير والوعيد، أو تعداد النعم أو النقم، أو الترهيب والترغيب والتخويف، أو تجديد

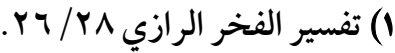

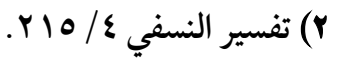

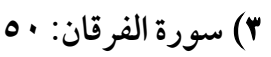

$$
\begin{aligned}
& \text { \&) الوجوه والنظائر / Y / }
\end{aligned}
$$

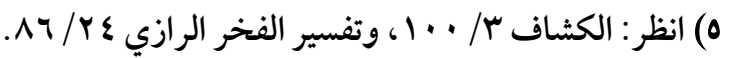




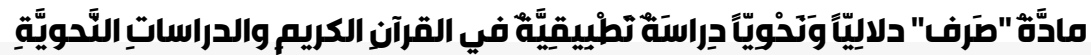

الوعظ وتنويعه، أو بيان الأحكام وتفصيلها.. ونحو ذلك من الأغراض القرآنية، . وعلى هذا أيضًا نجدها في صيغة الفعل المضارع من المضعَّف العَيْن، بهذه المعاني المجازية المتفرعة من الدلالة الأصلية، كما في الآيات التالية:

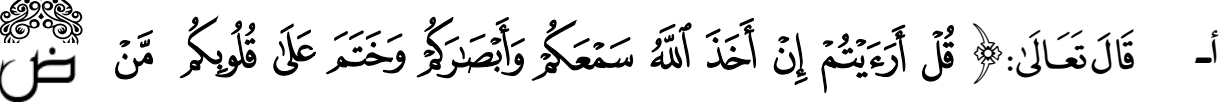

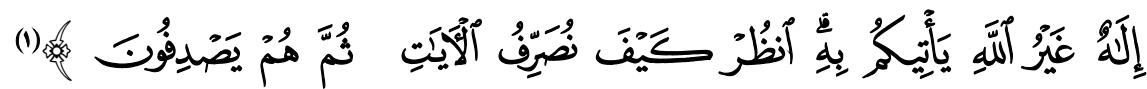

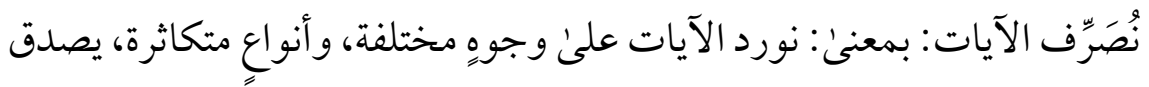

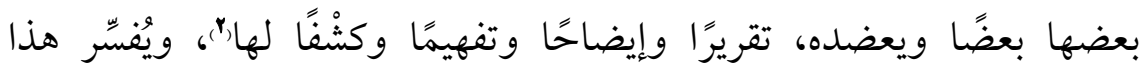
التصريف تأويله بالتخويف بأخذ الأبصار والأسماع والقلوب، وبالإخبار عما صُنِع بالأمم السابقة، وبأنها تأتي بالنقمة تارةً، وتارة بالنعمة، وتارة بالترغيب، وتارة بالترهيب، وبتتابع الحجج وضرّب الأمثال، وبالتوجيه إلى الإنشاء والإفناء والإهلاك..ذكر هذا كله أبو حيان عن بعض أئمة التفسير(r)، ولعموم "التصريف" في الدلالة على قلْب الشيء وتنويعه وتحويله علىن أَْجِهِ وأحوالٍٍ متغايرة نجد أنه يشمل هذا كله ونحوه من المعاني المجازية والسياقية المرتبطة بالدلالة بهذه الدلالة الجذرية للمادة.

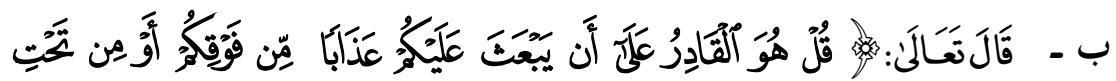

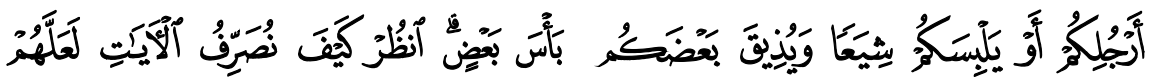

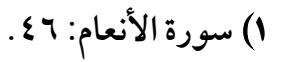

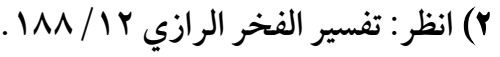

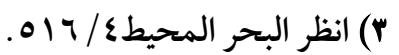




\section{مجلة كلية اللغة العربية بالمنوفية العدد الخامس والثلاثون - إصدار ديسمبر 2020م}

बac

(1)

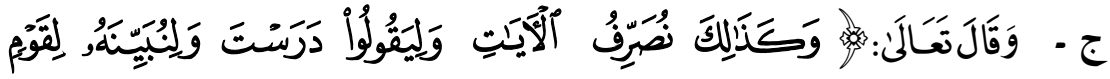

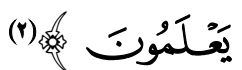

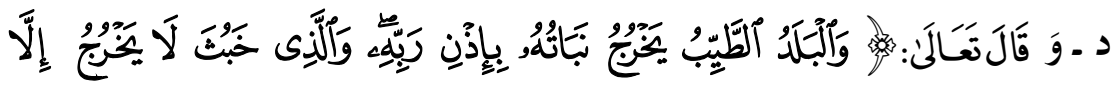

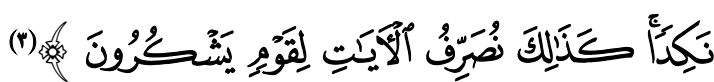

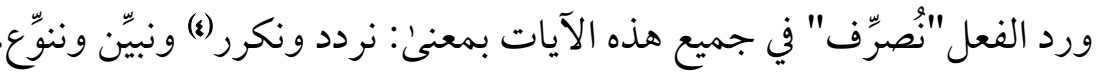
وننقل الآيات من حالٍ إلى حالِ، ومن جهةٍ من النظم والتعبير إلى جهةٍ مختلفة، ونغيّر ها لتو افق ما هو مطلوب من التغيير والرجوع، وتزيد صيغة المضارع هنا في

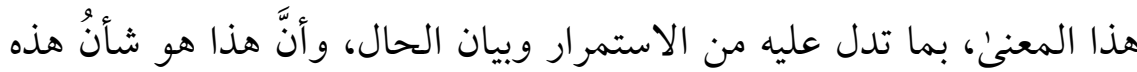
الآيات المنزلة من الله تعالىي، بما تحمله من الأحكام والمواعظ والبيّنات

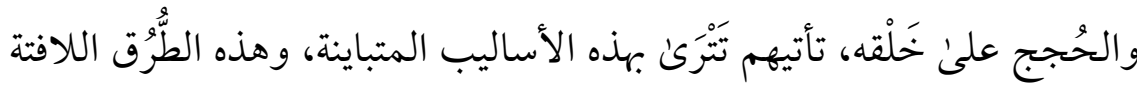
للأنظار، والمنبِّهة لأولى الأبصار، لاتزال تتكرر وتتردد عليهم للدلالة على تلني

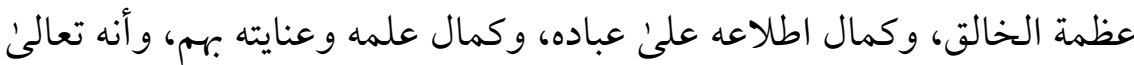

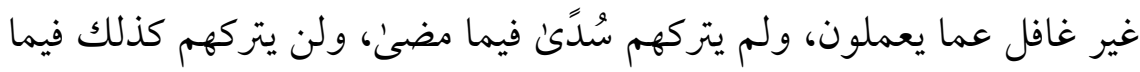

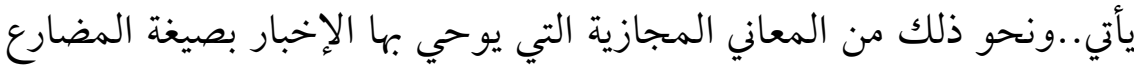
من هذه المادة اللغوية، مقارِنة لهذه السياقات القرآية. قال ابن عاشور رحمه الله: "تصريف الآيات تنويعها باعتبارِ ما تدل عليه من

$$
\begin{aligned}
& \text { (1) سورة الأنعام: } 10 . \\
& \text { ( الأنعام: 1. } 1 .
\end{aligned}
$$

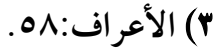

$$
\begin{aligned}
& \text { §) انظر: تفسير النسفي ץ/10. }
\end{aligned}
$$




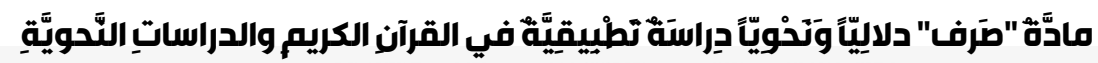

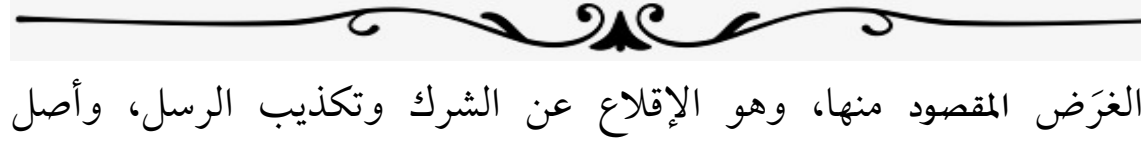
معنى "التصريف" التغيير والتبديل؛ لأنه مشتق من "الصرف" وهو الإبعاد، وكنئ

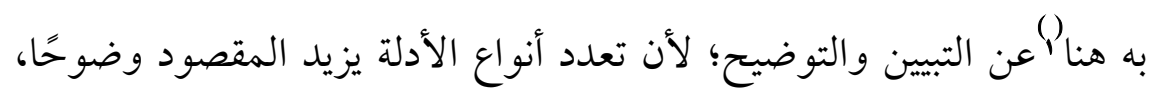
ومعنى تنويع الآيات أنها تارة تكون بالحجة والمجادلة النظرية، وتارة بالتهديد على الفعل، وأخرىن بالوعيد، ومرة بالتذكير بالنعم وشكرها"(r) ومِن بليغ دلالِِ استعمال هذه المادة في السياقات القرآنية: أنَّها استُعملَتْ في

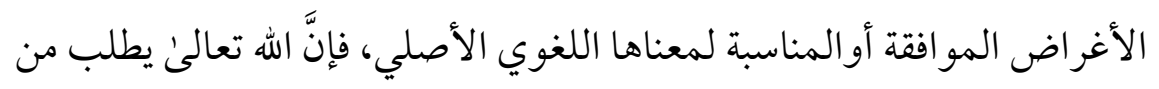
عباده في هذه الآيات تغيير سلوكهم الخاطئ، وتبديل أحوالهم المخالفة لشرعه، ورجوعهم من الضلال والانحراف إلى الاستقامة على الفِطرة السليمة التي فطَرهم عليها، ويريد منهم أن يفهموا ويفقهوا أمره ووعظه، وأن يعتبروا ويذّكروا، وهذا يقتضي تغيير الحال، وتجديد الانتباه، وقلْب الأمور إلى المأمور به، فعَبَّ عن فئن ذلك كله ونحوه من المعاني المجازية بمادة "التصريف" المتضمنة لهذا المعنى لئن أصالةً، وهذا من عجيب النظم القرآني و إعجازه الفذّ الذي لا يُلحَقَ و لا يُجارَنا.

米米粠米粠米

\section{ع - صيفة المصلدر من الرباعي بالتضعيف "تصريف"}

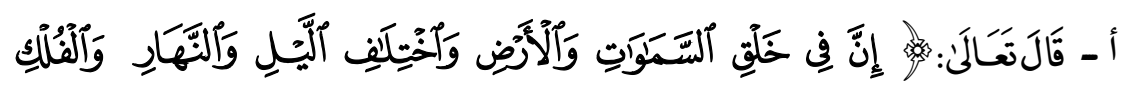

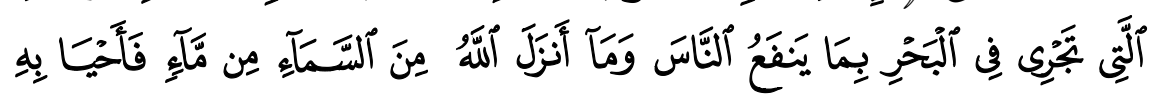

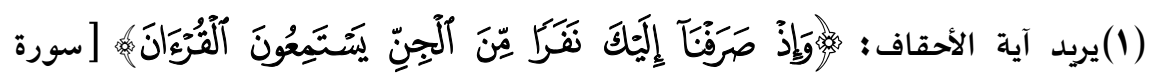

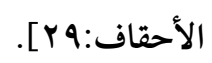

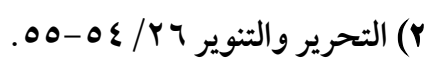




\section{مجلة كلية اللغة العربية بالمنوفية العدد الخامس والثلاثون - إصدار ديسمبر 2020م}

\section{9人e}

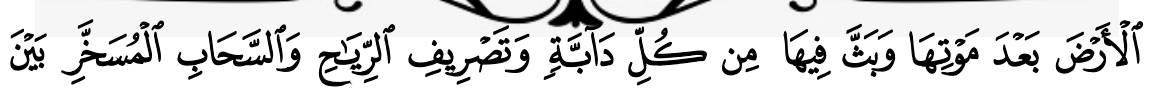

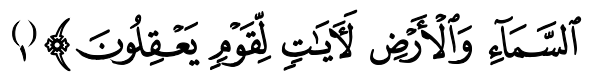

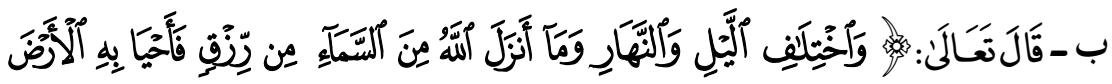

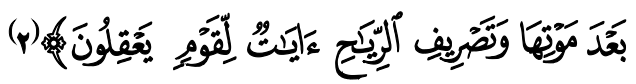

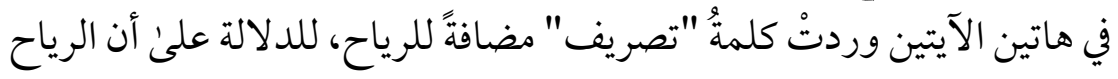

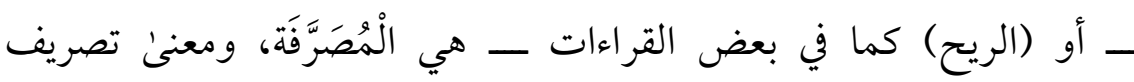

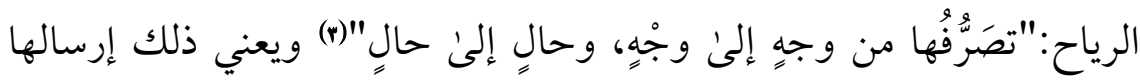

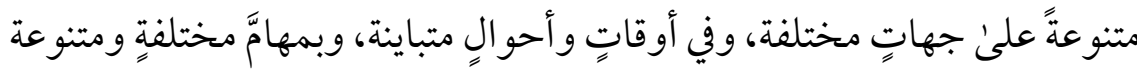

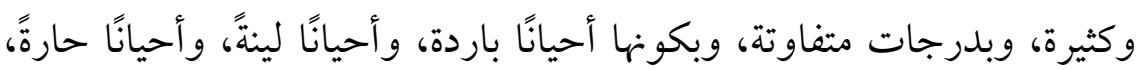

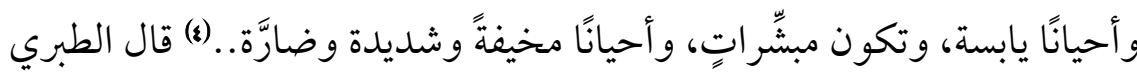

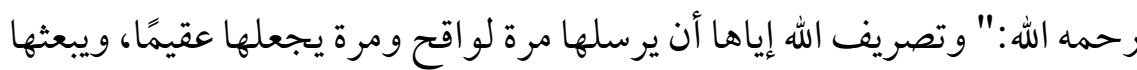

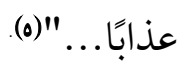
ويَلحظ المرء هنا أيضًا المناسبة الدقيقة للدلالة اللغوية لِمادة "صرف" على

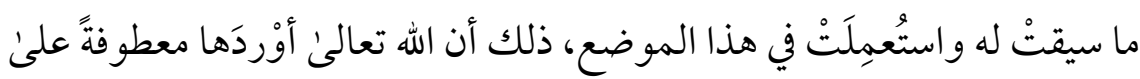

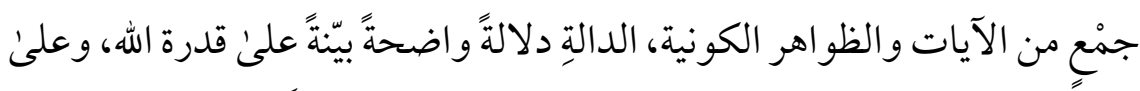

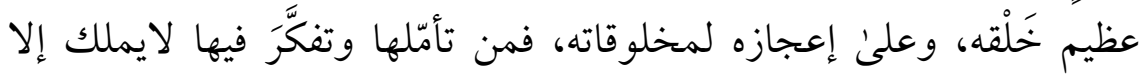

$$
\begin{aligned}
& \text { 1) سورة البقرة: \&17 } 17
\end{aligned}
$$

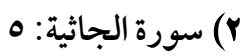

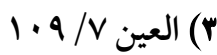

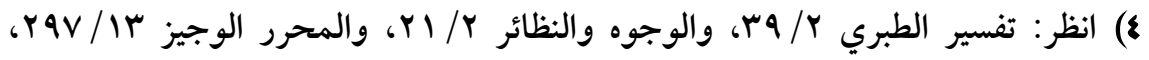

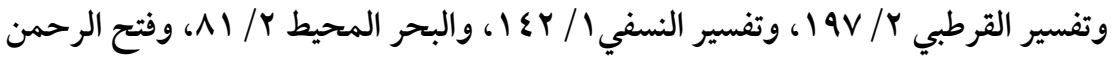

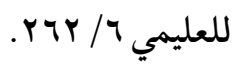

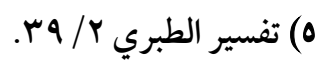




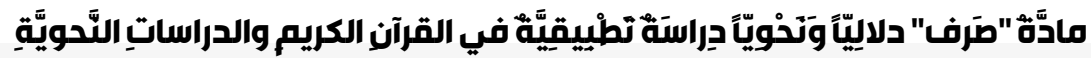

الاستسلام لتوحيد الله واتباعِ رسوله، وليس أمامه مجالٌ للشك في قدرة الله، ورَمَّاً كانت الريح من أعظمِ مخلوقات الله، وأعجبِها وأعجزِها للعقل البشري؛ لتعلّق الحياة بها من جميع النواحي، وقوةِ تأثيرِها، وظهورِ منافِِها ومضارِّها، مع كونها

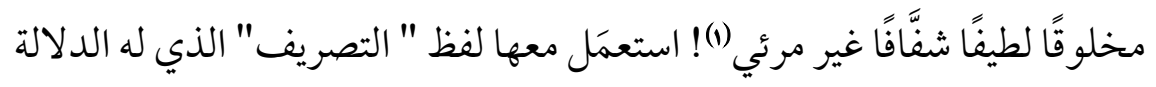
الكاملة والشاملة لهذه المعاني جمعاء؛ لأنها امتدادات مجازية للدلالة الجذرية لهذه المادة اللغوية.

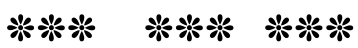

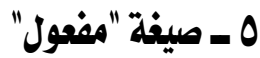

وردتْ هذه الصيغة في القرآن مرةً واحدةً في قول الله تعالىي:

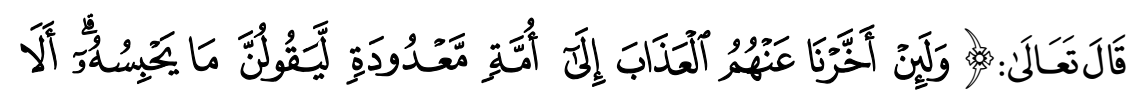

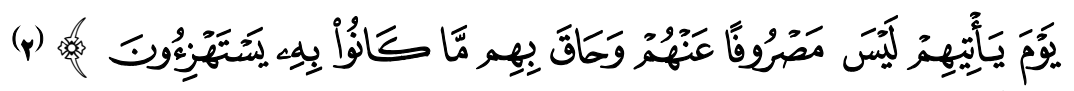

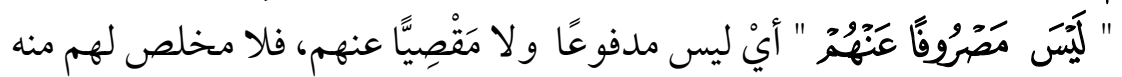
بحالٍ، بل سيكون محيطًا بهم(ه)، و الدلالة اللغوية الجذرية هي المتقدمة نفسُها سبق، ولكن صيغة "المفعول" هنا تفيدُ بقرينة ما قبلها وما بعدها أن المر اد تهديد

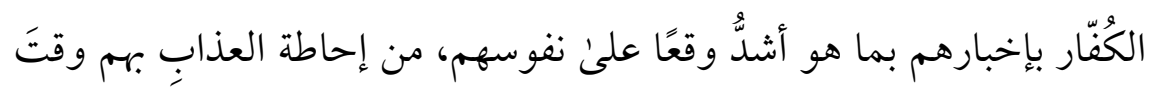

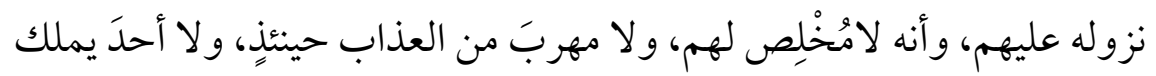

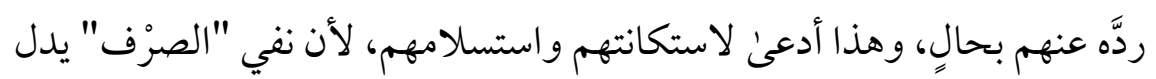

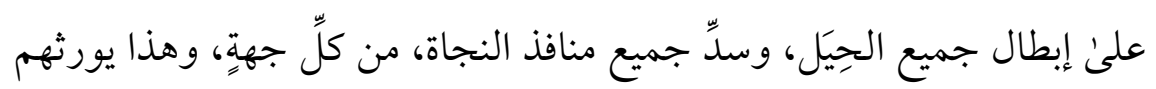

1) انظر البحر المحيط Y / 11.

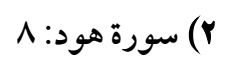

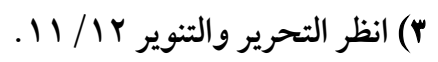




\section{مجلة كلية اللغة العربية بالمنوفية العدد الخامس والثلاثون - إصدار ديسمبر 2020م}

اليأس من الطمع في الخَلاص من عذاب الله، أو حصول مهملة للتوبة والرجوع

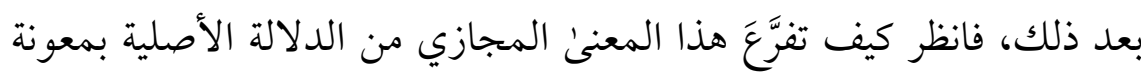

$$
\text { صيغة "مفعول"! }
$$

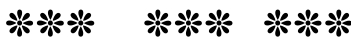

\section{7 ـ صيغة "مَفُعل" الدالة على المكان}

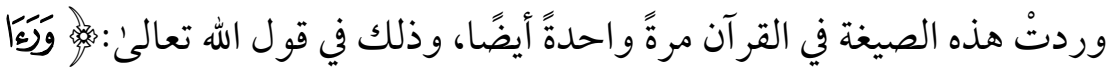

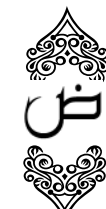

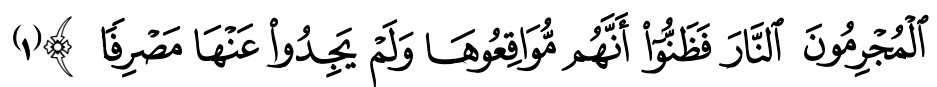

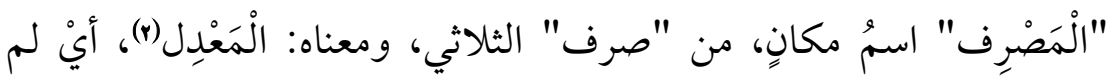

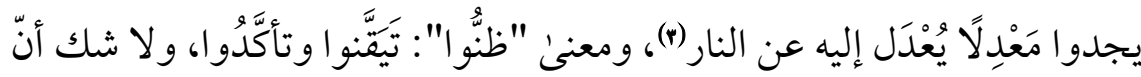

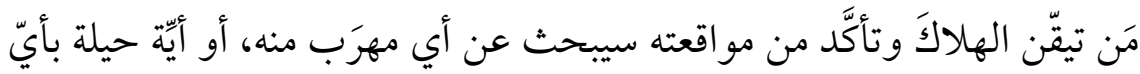

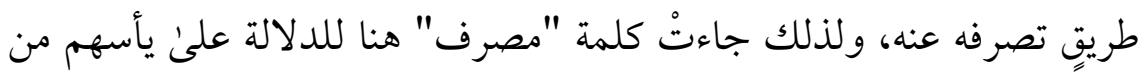

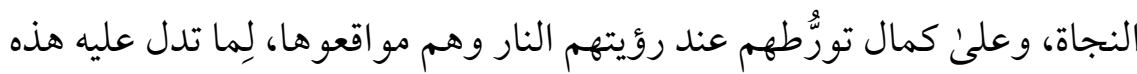

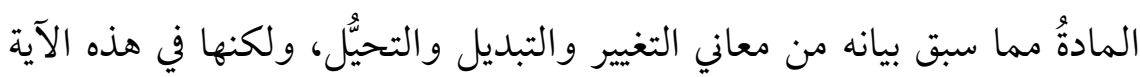

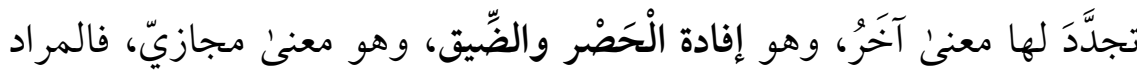

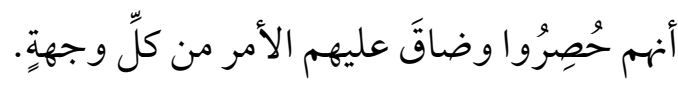

$$
\text { 1) سورة الكهف: سه. }
$$

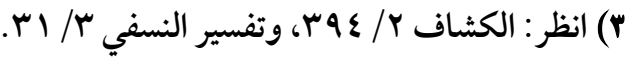




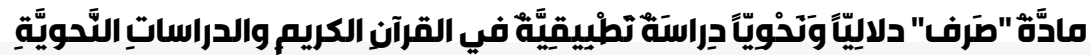

قال الَشاعر:

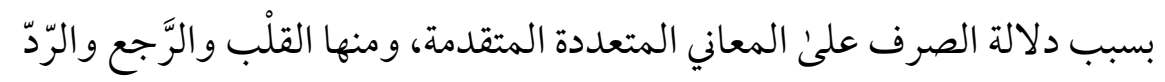
والتحوُّل والتغيير، بأيِّ وِجهةٍ وعلى أيَّة حالٍ، ومن هنا نجد قوة دلالة لفظة "مَصْرِفِ" على هذا تناسب نزولَ الشيب بالمرء؛ لأنه إذا نزل فلا مَصْرِفَ عنه ولا مهرب، ولا حيلة تدفعه عمن نزل به، ولذلك نجد أن اللفظ الذي يُعبِّ عن هذا بإحاطة كاملةٍ، ويفيده بدقة، هو لفظ" مَصْرِف" المشتق من "صَرَف" دون غيره.

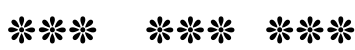

خلاصة ما دلَّتْ عليه كلمة "صرف" يِّ القرآن بجميع تصاريفها الواردة

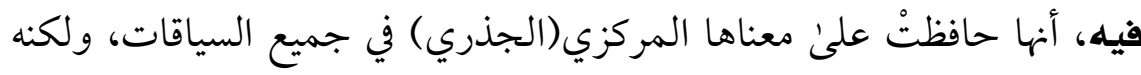
اتََّع فاكتسبت الكلمة معانِيَ فرعية جديدة، واتسعتْ دلالتها مجازيَّا لتمتد إلىلى أغراض متعددة، واستعمالاتٍ متنوِّةٍٍ، ومجالاتٍ كثيرةٍ، فرضها السياق و المناسبة التي وردتْ معها في كل آية، وكان من أهم مظاهر هذا الاتساع الدلالي مناسبة معناها الأصلي لكثير من الأغراض القرآنية، كالوعظ، والتقرير، و الإعجاز، والتبين، والتبصير، وطلب النجاة، والوعد، والوعيد، والكشف عن

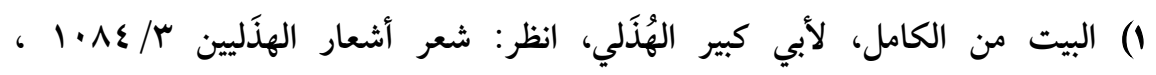

$$
\text { واللسان(صرف) }
$$

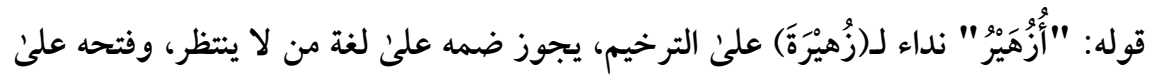

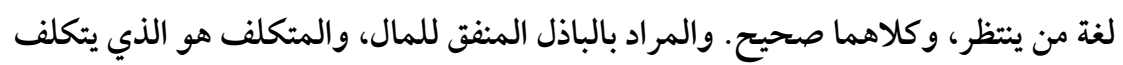
البذل إذا لم يجد شيئًا ينفقعه. 


\section{مجلة كلية اللغة العربية بالمنوفية العدد الخامس والثلاثون - إصدار ديسمبر 2020م}

حقيقة أمر ما، والإفصاح عن الحكم الشرعي، والبعث، والإرشاد والتوجيه، والدعاء، والتعبير عن جحود الكفار وعنادهم وضلالاتهم، والتعبير عن انحراف المنافقين وفساد أمرهم، والكشف عن المغيبات وحقائق الأمور، وتعداد النعم....وغير ذلك مما تقدم.

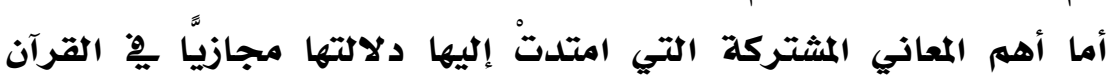

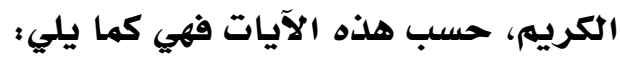

\begin{tabular}{|c|c|c|c|}
\hline الشيء،أو التحوّل إليه عن & r.الرجوع. & r. rالتوبة. & و التصرّف. الاحتيال. \\
\hline و التبصير. عدم التوقيق & V V. الإبعاد. & 7 ـالمجازاة. & 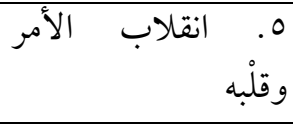 \\
\hline بالشيء. عدم الاهتمام & 11 ا المنع. & • 1. الحماية. & و.إنشاء الدعاء على \\
\hline الشيء والاهتمام به. & 10 ـ التوجيه. & ع ا.الإرسال. & الشيء. الإعراض عن \\
\hline الشي.عدم التمكين من & 19 ـالتبصير. & و 1 الإمالة. & 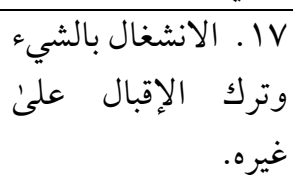 \\
\hline وجاء و إيراد الشيء على ومتئ & بَّ. الصدّ. & r r البعث. & آ. ا.دفع أمْرِ. \\
\hline 人 Y. الترك & VV & آ ـالإضلال. & و الضِّ. الوقوع والانحصار. الورطة \\
\hline rr r.النجاة. & آس. الإعراض. & • •r.الصدود. & q.العذاب. \\
\hline بr. التفهيم. & هץ. المبالغة. & 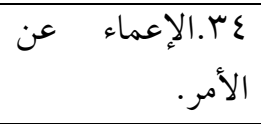 & سب. التوكي. \\
\hline •ع .التبيين. & q" الدفع. & الشَ. الغفلة عن & VV r. التفصيل. \\
\hline و ع الابتعادة $\quad$ الاندفاع & بـ التكرير. & Yع .التنويع. & إ ـالتكثير. \\
\hline ع ع .التعداد. & V ع .التوضيح. & 7 ع. التمييز. & o 8 .الترديد. \\
\hline
\end{tabular}




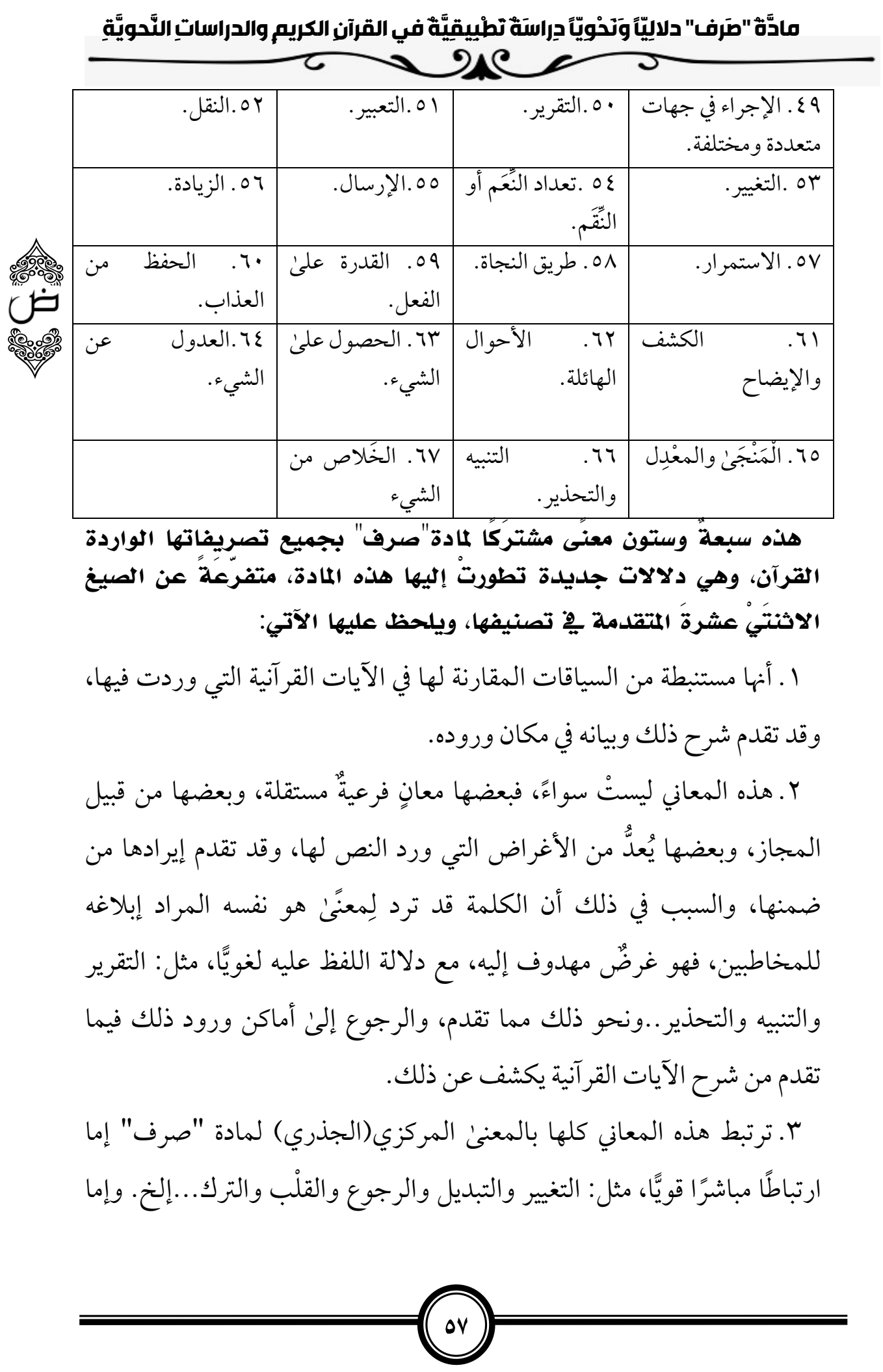




\section{مجلة كلية اللغة العربية بالمنوفية العدد الخامس والثلاثون - إصدار ديسمبر 2020م}

ग्रe

ارتباطًا مفهومًا ضِمْنِيَّا، استنبطه المفسرون واللغويون بمعونة السياق وأغراض النص، كما تقدم.

ع ـ من يقرأ هذه الكلمات فقد لا يتبادر إلى ذهنه شيء من التعالق والترابط فيما بين طائفة منها، ولكن من ينعم النظر في معانيها الدقيقة والأغراض التي سيقتْ

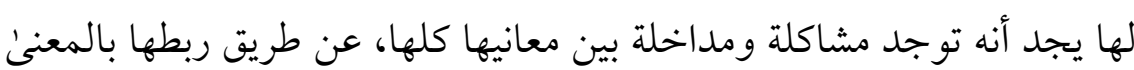
الجذري الأصلي لمادة "صرف"، وذلك يجعلها معانيَ فرعية له، كما هو مقرر عند علماء الدلالة)(1)؛ لأن الاتصال والترابط بين مدلو لات الكلمة ـ ولو بأدنَئ ملابسة ـ يحصل من تعلقها بالمعنى الأصلى لتلك الكلمة، سواء أكان الاتصال

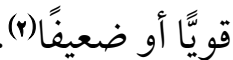

•. بعض هذه المعاني مستفاد من الصيخ الصرفية للكلمة، فهي معانٍ صرفيةٌ مضافة للمعنى اللغوي الأصلي للكلمة، مثل: الْمَنْجَى و الْمَعْدِل، والخَلاص من الشيء، والوقوع في الورطة و الضِّيق والانحصار ..ونحو ذلك مما يُفهم من نفي

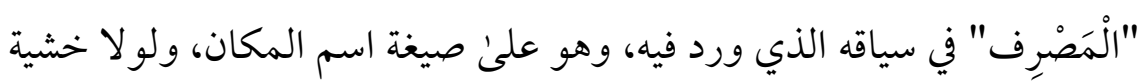

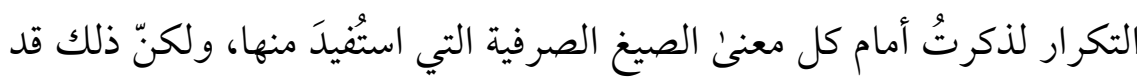
تقدم في أثناء شرح الآيات، فثمَّ إيضاح لكل معنى ومصدره من النص القرآني. 7 . عندما نعود إلى المعاني اللغوية التي ذكرتها المعاجم لهذه المادة، ثم ننظر إلى معانيها التي جدّتْ لها في القر آن الكريم، نجد أنه قد حصل اتساعٌ دلاكيّيُ لهذه المادة اللغوية، يُستدلّ عليه بارتباط معانيها الفرعية بالدلالة المركزية

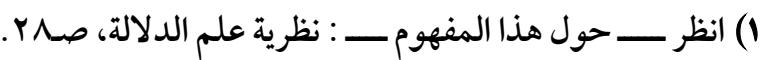

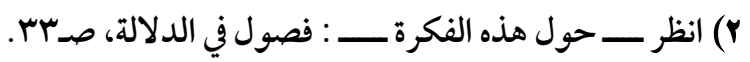




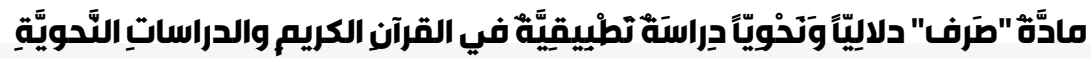

لكلمة"صرف" وبارتباط عامٍ لهذه الكلمات في مدلولاتها في بعض السمات الخاصة بكل واحدة، وهي متشابكلة فيما بينها بمفاهيم يتصل بعضها ببعض في الذهن، وهذا من أهم سمات الاتساع الدلالي (1)، ومن أمثلته الترابط الدقيق بين مفاهيم: التقرير والتوضيح والتعداد، والتنويع والتقسيم، والبعث والقدرة

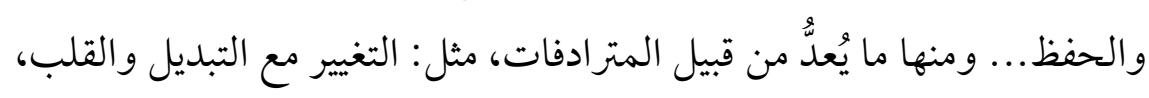

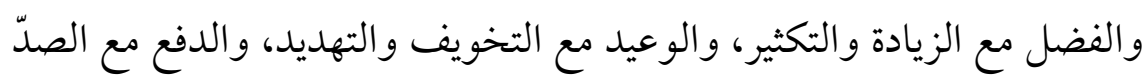
والمنع..وهكذا. وهذا كله يدل علىن أنّ الجانب التطبيقي هو أهم مجال لإظهار معاني اللغة ودلالات ألفاظها، وقدرتها على التعبير عن المعاني.

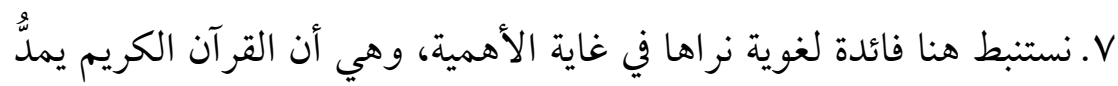
اللغة العربية بقدرة عالية على استعمال الكلمات للمعاني وفق الأغراض المطلوبة، وأنَّ الأبعاد الدلالية للمشتقات العربية علىن هذا القياس في الاستعمال لاحدود لها، بل تمتد بلا نهاية محددة؛ لأنها ترتبط بحاجة المنشئ للكلام، وأغراضه، وبأنظمة العربية وقو انينها التي تحميها من الانحراف، وهذا يعطيها

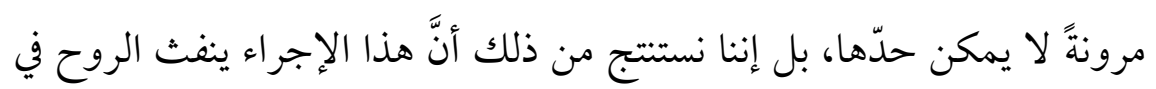
اللغة العربية، ويجدد نشاطها وقوتها باستمرار ما دامت الحياة قائمة. 楼楼楼楼

() انظر: فصول في الدلالة، صـ99. 


\section{رابعاً: هادة "صرف" في الدراسات النمصوية}

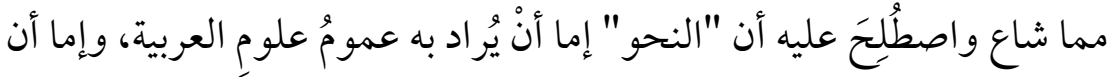
يُرادَ به الجانب التركيبي، وهو الجانب الذي يدرس الجُمَل النحوية، وهذا الأخير هو المتبادر إلى الذهن عند الإطلاق؛ تغليبًا. و"الصرف" و"الانصراف" و"التصريف" و"التصرُّف" مصطلحات تَرِد في الدراسات النحوية بكثرة، وكلها مشتقة من مادة "صرف" على ما تقدم بيانه

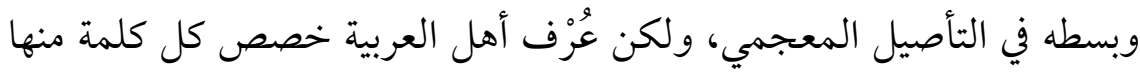

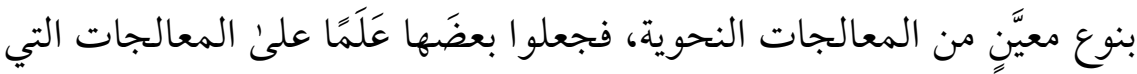

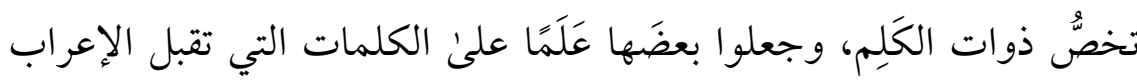

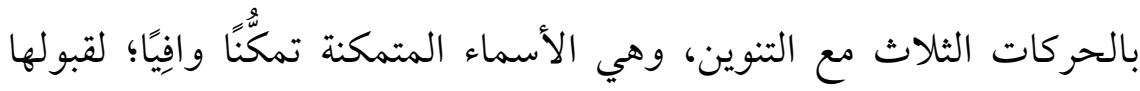
جميع التغييرات التي يوجبها الإعراب(1)، وبعضها للكلمات التي تقبل مطلق الانتقال من حالٍ إلى أخرى في الاستعمال، وسيأتي تفصيل هذا قريبًا إن شاء الله.

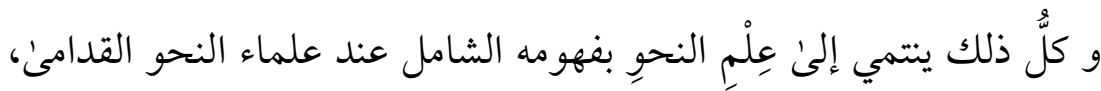

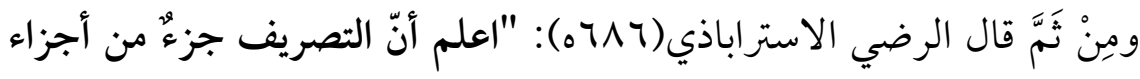
النحو بلا خِلافٍ من أهل الصناعة"(()، وكذلك يرئ المتأخرون في الدراسات

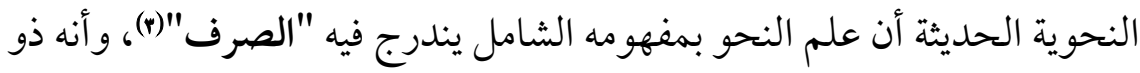

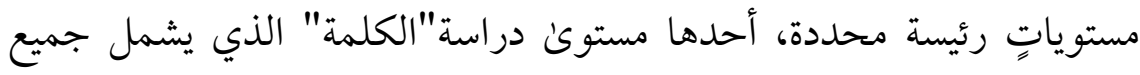

$$
\text { 1) انظر : ما لا ينصرف للزجاج، صــ. }
$$

ץ) انظر : نشأة النحو وتاريخ أشهر النحاة لمحمد طنطاوي صـ ؟ ب. 


\section{CNC}

المعالجات الصرفية(1)، وأما من جهة التفصيل فقد تطوَّرتْ الدراسات النحوية،

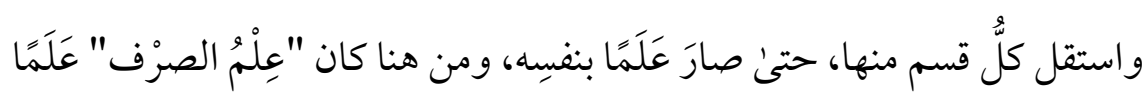

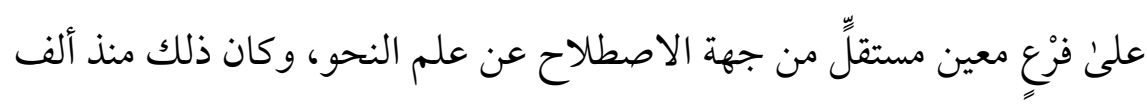
أبو عثمان المازني(YV Y Iه) كتابه في التصريف، وخصصه للمباحث الصرفية، وأخلىن منه المعالجات التركيبة وأحو ال الإعراب، وجرىن على سننه جمع من العلماء فألفوا كتبًا في التصريف مستقلة، واستمرّ ذلك إلى يو منَّا هذا. و "التصريف" في أصله مصدرٌ مطاوع لــ(تَصَّفَ) المضعَف من (صَرَفَ)

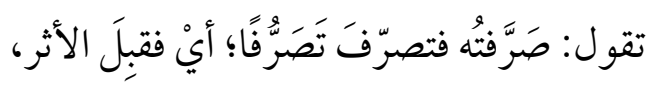
وهو التصريف والتّصرُف (r)، بمعنى قَبِلَ أن يتصرَّف، كما أن "الانصراف" في أصله مطاوعُ لـ(صَرَف) (r) فوقعت التسمية والوصف بهما لمناسبة هذه المطاوَعة التي مصدرها قبول أثر الفعل "صَرَف" المشتق من مادة"صرف"، قال

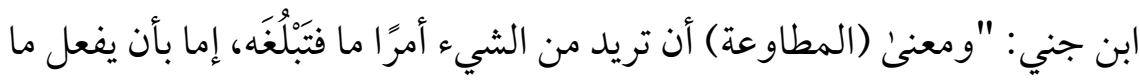
تريده إذا كان مما يصح منه الفعل، وإما أن يصير إلى مثل حال الفاعل الذي

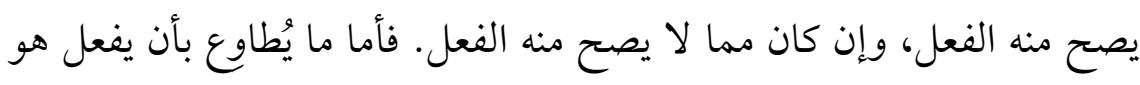
فعلا بنفسه فنحو قولك: "أطلقته فانطلق، وصَرَفْته فانْصَرَفَ"، ألا ترىن أنه هو

1) انظر: جامع الدروس العربية للغلاييني صه - • (1، المدخل إلى علم اللغة ومناهج البحث اللغوي صه911، والتطبيق الصرفي للراجحي صدV-1. ودراسات في فقه اللغة لصبحي

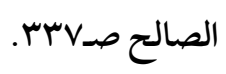

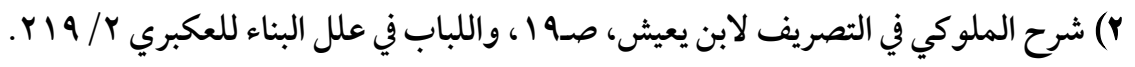

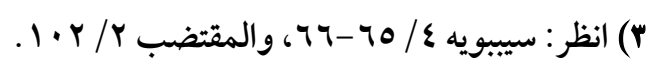


الذي فعل الانطلاق، والانصراف بنفسه، عند إرادتك إياهما منه، أو بعثك إياه

$$
\text { (1)" عليهما }
$$

يريد أنّ ما تريده يحصل لك باستجابة المأمور الذي أمرته فطاوَعك وفعَل ما

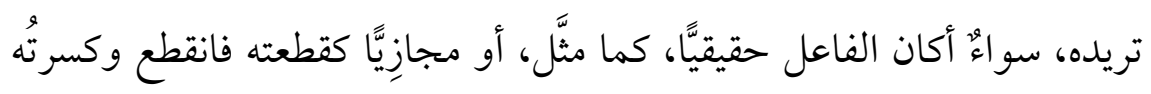
فانكسر، كما ذكر بعد ذلك.

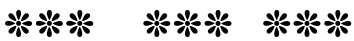

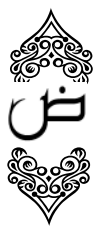

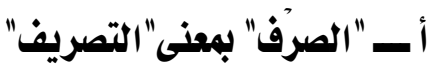

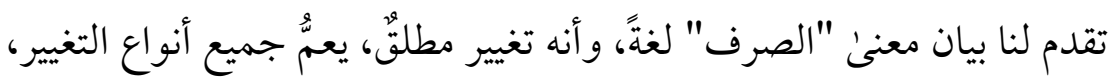
كالتحويل والقلب والرد والزيادة والنقل، ونحو ذلك مما تقدم، ومن هذا المعنى اللغوي انطلق النحويون فخصصوا مطلق "التغيير" بألفاظٍ مشتقة من مادة

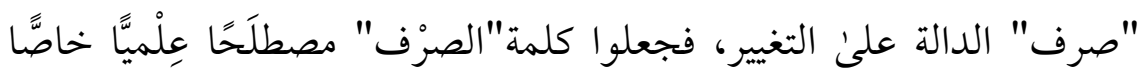
بشطرٍ من الدراسات النحوية، يتناول كلمات اللغة مفردة معزولةً عن التركيب، بإِحاق التغيير بألفاظ أصولها وذواتها؛ لأسبابٍ صوتيةٍ، أوْ لِتحصيل معانٍ

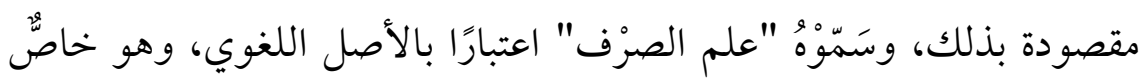
بالأسماء المتمكنة والأفعال المتصرِّة (r). وعلى هذا يُعلم أن مصطلح "الصرّف" عامٌّم من جهة معناه اللغوي لجميع

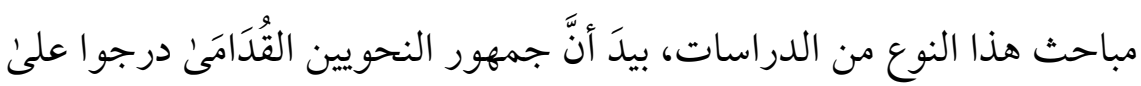
تسميته بـ(التصريف) وغَلَّبوا هذا اللفظ؛ لأن "التصريف" أصله من من ان

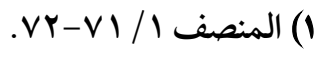

r) انظر المفراح في شرح مراح الأرواح في التصريف، صده، وشرح الملوكي في التصريف، 


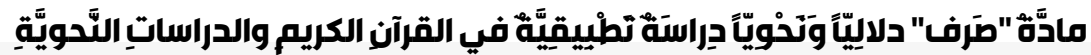

مادة"صرف" كما تقدَّم، وهو في الأصل للدلالة على التكثير من الفعل، أين الزيادة في التغيير، فأصله أنه خاصٌّ باشتقاق الكلمات من الأصل، علىن ما تقدم في مبحث "مأحذ التصريف من الاشتقاق" نحو: صَرَفَ ــ تصرّف ــيُصَرِف ــ ـ

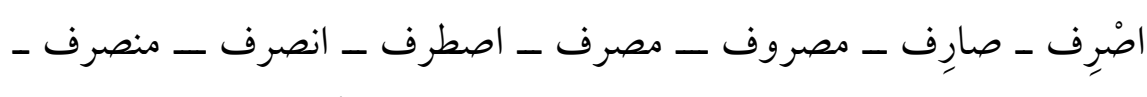
متصرَّف...إلخ. فهذا هو الاشتقاق من الأصل، وهو خاصٌّ في هذا الإجراء بأبنية

$$
\text { "التصريف" وتغيير صيغة إلى أخرى (1)؛ لتوليد معانِيَ جديدة. }
$$

وبعضهم قصرَه على التغيير الذي يطرأ لأسبابٍ صوتية، يقتضيها النطق بالكلمات، وخصائص عناصرها الصوتية(r)، وبعضهم جعله عامَّا في كل تغيير

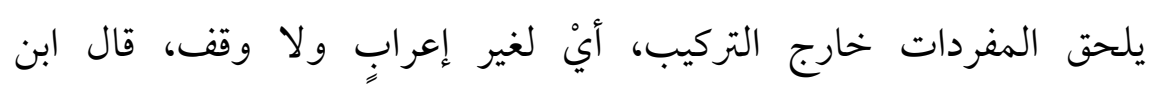

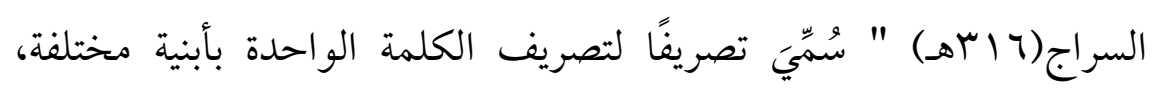
وخصّوا به ما عرضَ في أصولِ الكلام وذواتها من التغيير، وهو ينقسم خمسة

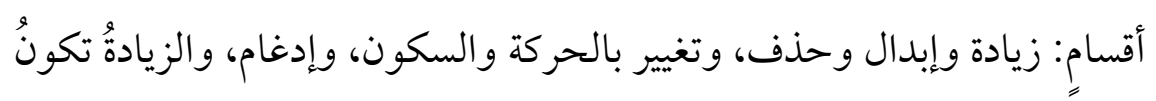

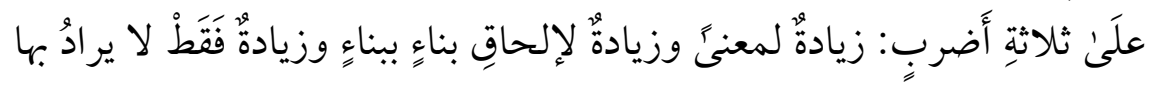

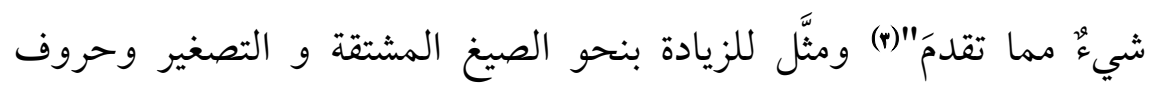

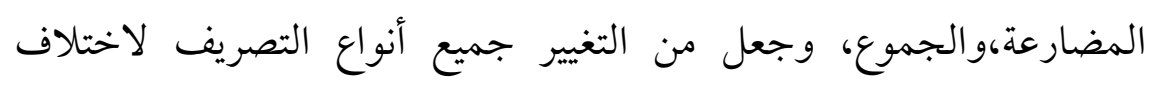

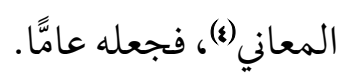

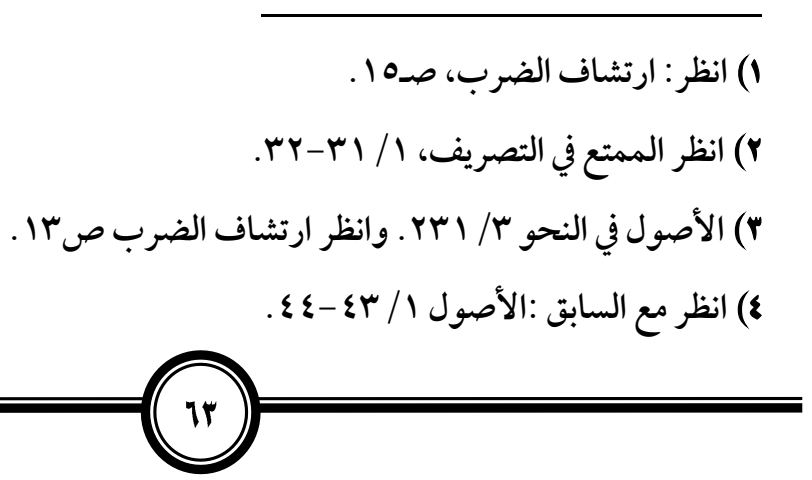




\section{مجلة كلية اللغة العربية بالمنوفية العدد الخامس والثلاثون - إصدار ديسمبر 2020م}

رe

وقال ابن جني: "التصريف: أن تجيء إلى الكلمة الواحدة فتصرّفها على

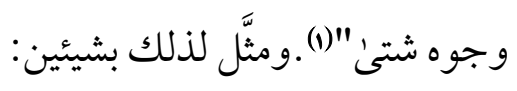

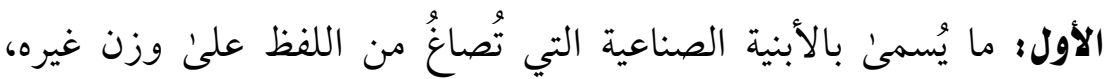

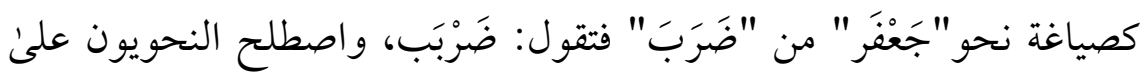

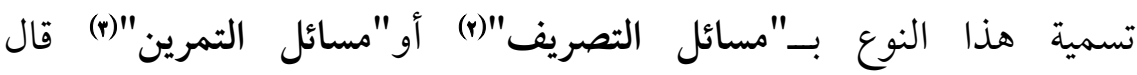

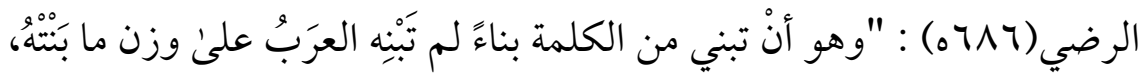

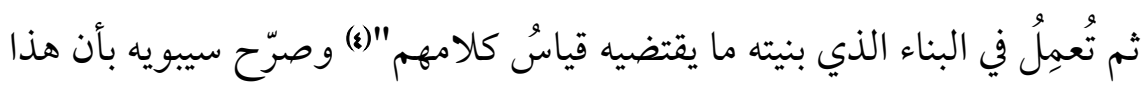
هو الذي يسميه النحويون: التصريف(ه) الثاني: الاشتقاق، وهو تفريع الكلمة إلى مشتقاتها القياسية(1)، كصارف

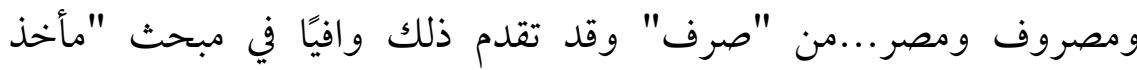

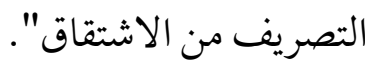

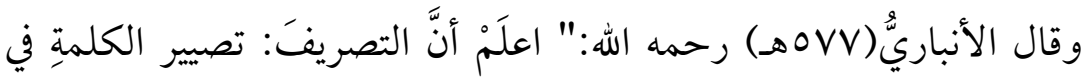
أبنية مختلفة؛ لأن تصريف الشيء تصييره في جهاتٍ مختلفة"(v) وظاهر هذا

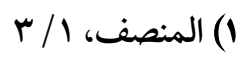

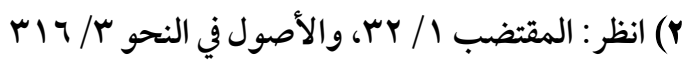

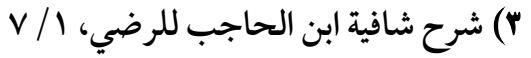

$$
\begin{aligned}
& \text { §) السابق نفسه }
\end{aligned}
$$

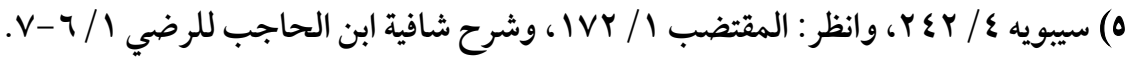

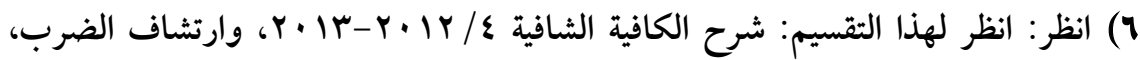

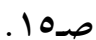

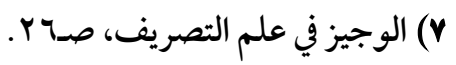




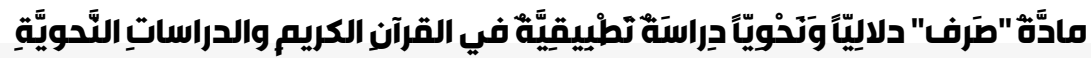

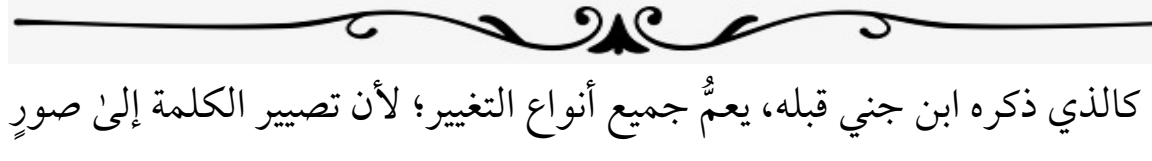
مختلفة يعمّ الأبنية المشتقة وغيرَها، وتدخل فيه الصيخ الصناعية والسماعية،

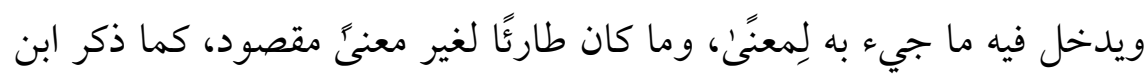

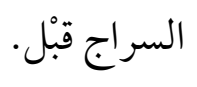

وقال القبيصي(حوالي: • ب7ه) : "التصريف أنْ تأتِي إلىن الكلمة الواحدة التي

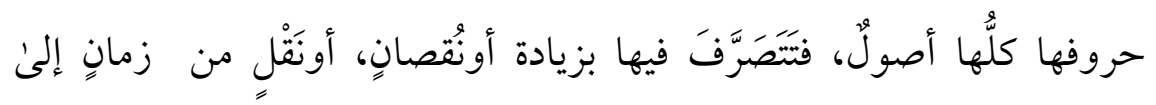
زمانٍ"(1) قوله: "أو نقل من زمالٍ إلى زمانٍ" يريد به تصريف الأفعال من الأصل

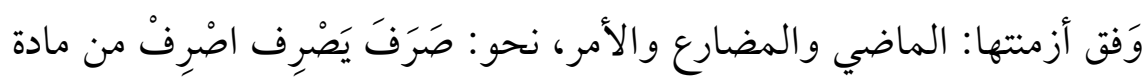

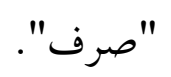

ولذلك قال ابن كيسان(99 Yهـ) رحمه الله: " الفعل يتصرَّف فيكون منه

الماضي والمستقبل والمصدر واسم الفاعل واسم المفعول..."(() فسمَّىن جميع المشتقات و أصولها تصريفًا.

فقد جعلوه خاصَّا بالأبنية، فإطلاقه على عموم مباحث علم "الصرّف " ـ كما

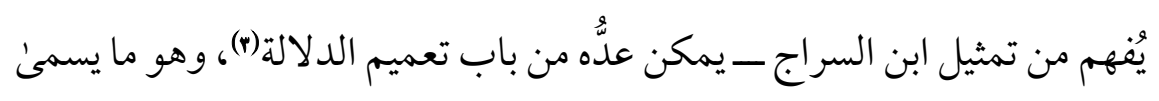
بإطلاق الجزء على الكل(§)، وتسميته بــ(الصرْف) عند قصره على الجانب

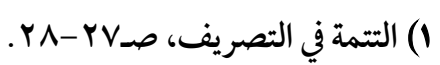

$$
\begin{aligned}
& \text { ץ) الموفقي في النحو، صـه ا. }
\end{aligned}
$$

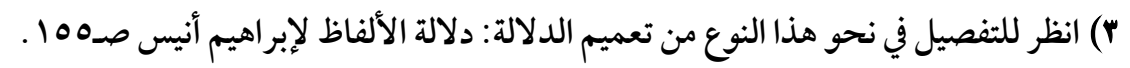

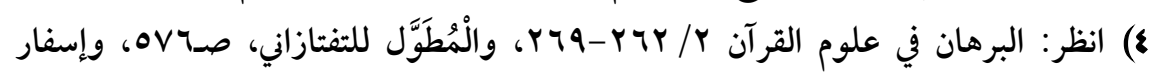
الصباح r / Tor. 


\section{مجلة كلية اللغة العربية بالمنوفية العدد الخامس والثلاثون - إصدار ديسمبر 2020م}

9re

الاشتقاقي فقط يُعدّ من تخصيص الدلالة، وهو ما يسمى بإطلاق الكل على

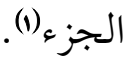

ويرئ العلَّامة سعد الدين التفتازاني(1)

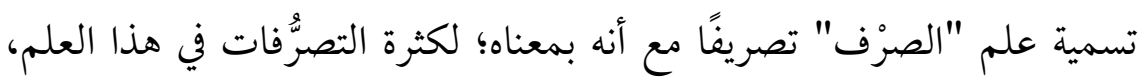
فاختاروا اللفظ الدالّ على التكثير والمبالغة، وهو"التصريف"(() يريد أنهم عمّموا دلالة "التصريف" مع أنه خاصٌّ بالأبنية في أصله؛ لأن المعنى اللغوي وهي لهذه الصيغة يو افق الإجراءات العملية لهذا العلم، من جهة ما يكون فيه من كثرة بكريك التغييرات و التحويلات. وهذا متجهُ، ولكن لا دليل على أنهم أر ادوا ذلك، ولذلك ذكرْتُ أنه من باب

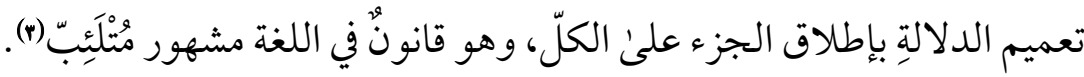

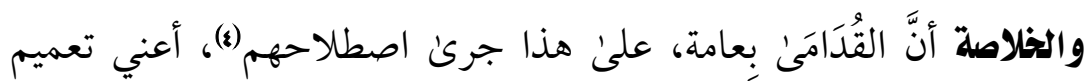
مصطلح "التصريف" على المباحث الصرفية، وإن كان بعضهم قد خصَّ به الجانب العملي(التدريبي) ويعضهم جعله مع ذلك لِما كان التغيير فيه لتوليد المعاني، كما تقدم، ولذلك قد ناقش ناظر الجيش(oVVA) مقالاتهم في تحديد المراد بالتصريف، ثم انتهن إلى أنهم قد يُطلقونه شامِلا للجانبين اللفظي

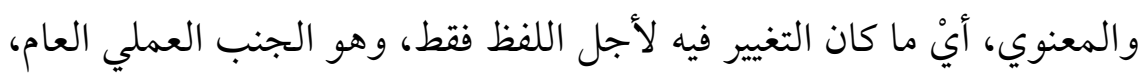

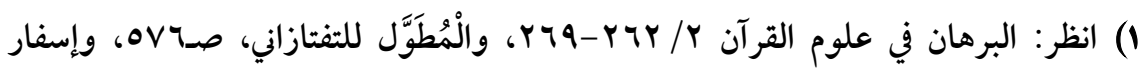

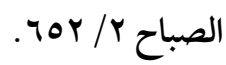

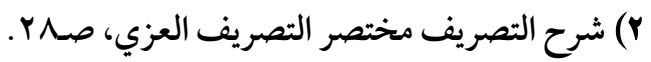

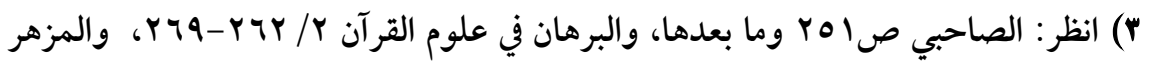

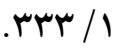

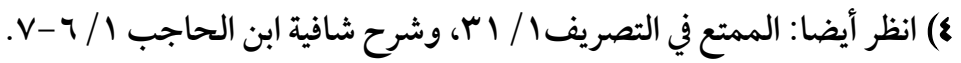




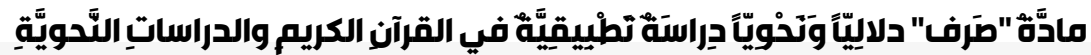

وما يكون لأجل المعنى، وهو الجانب العلمي الخاص، وقد يقصرونه على

$$
\text { أحدهما وهم مع ذلك يريدون الآخر (1). }
$$

\section{نهاذج من إطلاقاتهم للذّلك بِّ أثناء معالجتهم للمسائل :}

ا. قال سيبويه: "باب ما بنت العرب من الأسماء والصفات والأفعال غير المعتلة والمعتلة، وما قيس من المعتل الذي لا يتكلمون به ولم يجئ في كلامهم إلا نظيره من غير بابه، وهو الذي يسميه النحويون التصريف "(() فقصره على الأوزان، ونسب ذلك لعامة والنحويين. r. وقال المبرد: "وَهَذِهِ حُدُود التصريف وَمَعْرِفَة أَقَسامه، وَمَا يَقع فِيهِ من الْبَدَل

$$
\text { والزوائد والحذف "(r) فسمى التغييرات الصرفية كلها تصريفًا. }
$$

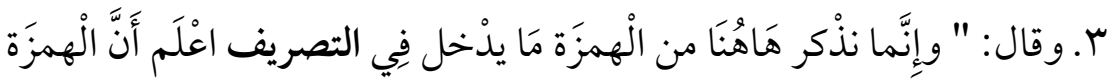

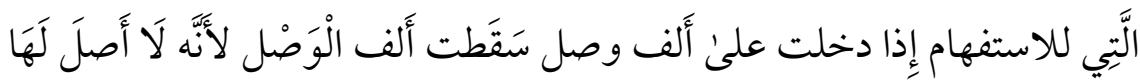

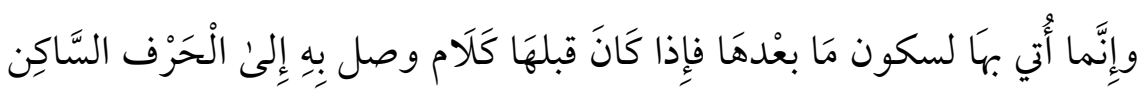
سَقَطت الأَلف" (๕) فعممه في مسائل الهمزة؛؛ لأنها من مسائل المفردات.

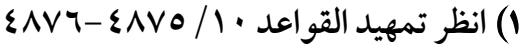

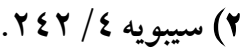

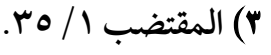

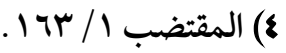




\section{مجلة كلية اللغة العربية بالمنوفية العدد الخامس والثلاثون - إصدار ديسمبر 2020م}

\section{ग19}

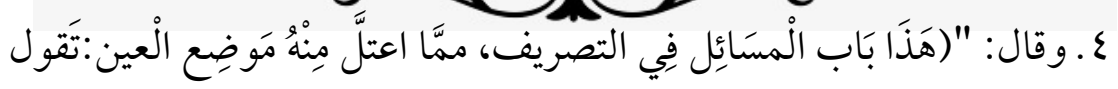
إِذا بنيت (فُوعِل) من (سِرْتُ): سُويرَ..."(() فقصر "التصريف" هنا على المسائل التدريبية العملية، كما فعل سيبويه.

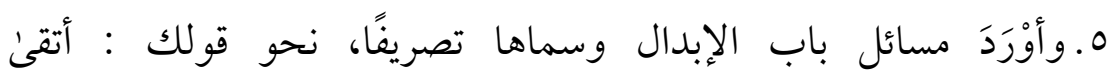

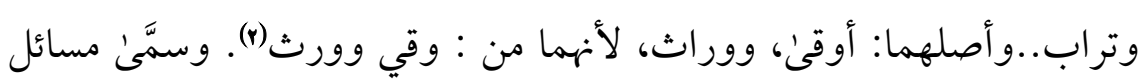
النسب بالتصريف(r)؛ لأنها من مسائل المغردات أيضًا.

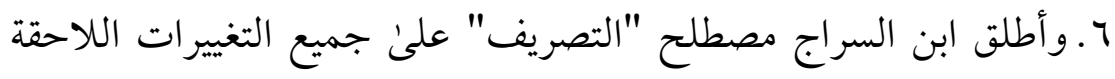

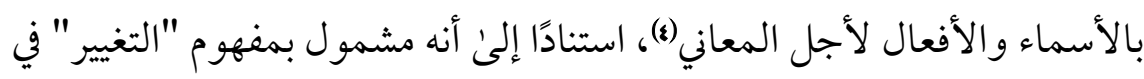

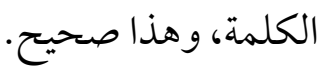

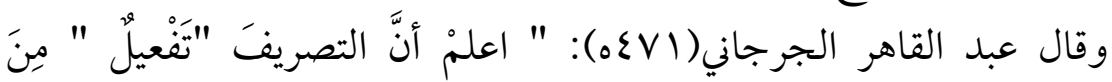

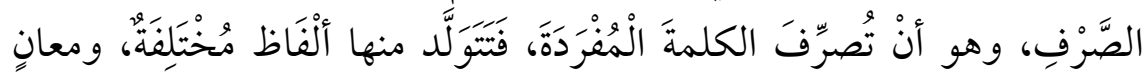

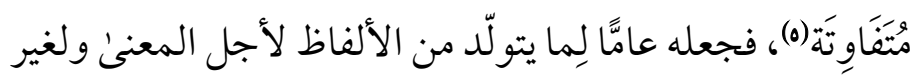

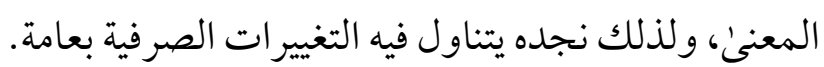

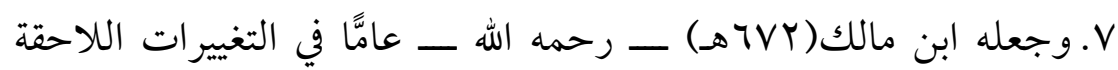
لأسباب تعود إلى المعنى أو إلى اللفظ، الفئ فقال: "التصريف تحويل الكلمة من بِنْيَة إلىى غيرها لغرضٍ لفظي أو معنوي" (ج).

$$
\begin{aligned}
& \text { IV / / المقتضب IV }
\end{aligned}
$$

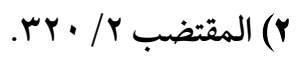

$$
\begin{aligned}
& \text { ץ) المقتضب / / } 1 \text { ا. }
\end{aligned}
$$$$
\text { §) انظر الأصول في النحو / / }
$$

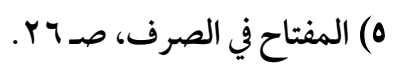

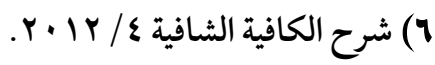




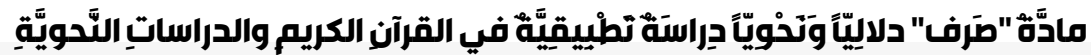

\section{$\longrightarrow$ Cac}

\section{أما الدراسات النحوية الحديثة: - مايثة}

فقد ارتضئ جمهور أصحابها استعمال المصطلحين معًا؛ لُِِّطلق المعالجات الخاصة بمفردات اللغة علىن مستوىن الأبنية والتغيّرات الطارئة، مما ليس ببناءٍ ولا إعرابٍ لدواعي المعنى أو اللفظ، وكذلك ما يصف المفردة اللغوية في هيئتها ومكوناتها الصوتية من الصوامت والصوائت، وتصنيفات أقسامها وأزمنتها، فجعلو ا مجاله أوسع، ينتظم مع ما سبق المعالجات الصوتية كلها(1)، وبعضهم وهم قلة فيما اطلعت عليه ـ قد قصر "التصريف" على بعض التغييرات التي لا يقتضيها المعنى((\$)، كالحذف والإبدال والزيادة ونحوها، كما مرّ عند بعض القدامى، بيد أنه قد غلب استعمال مصطلح "الصرف" في أكثر الدراسات الصرفية الحديثة، وغلب الاقتصار عليه في تسمية كثير من الكتب الخاصة بهذا النوع من الدراسات النحوية، ومن أمثلة ذلك: ا ـ كتاب "شذا العَرْف في فنٍّ الصرف"للشيخ أحمد الحملاوي. r r. كتاب "التطبيق الصرفي" للدكتور عبده الراجحي. r. كتاب "الصرف الوافي" لهادي نهر. ع. كتاب "المغني الجديد في علم الصرف" للدكتور محمد حلواني. ه كتاب "الصرف التعليمي" للدكتور محمود سليمان ياقوت.

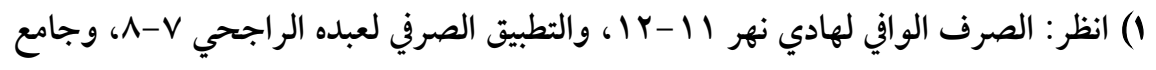

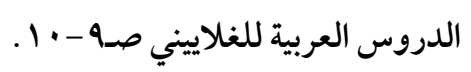

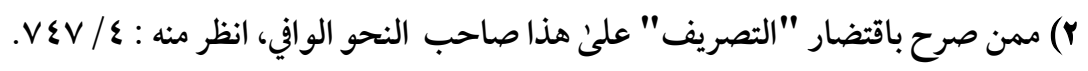




\section{مجلة كلية اللغة العربية بالمنوفية العدد الذامس والثلاثون - إصدار ديسمبر 2020م}

7. كتاب "قسم الصرف" من كتاب "تهذيب التوضيح" لأحمد المراغي ومحمد سالم علي.

V. كتاب "قسم الصرف" من تحقيق كتاب "شرح الرماني لكتاب سيبويه" للدكتور المتولي رمضان الدميري، هكذا سماه وطبعه مستقلا عن قسم النحو. هذه أمثلة قليلة، ولكني أراها كافية للتدليل على شيوع مصطلح " الصرف" عند المحدثين في تآليفهم.

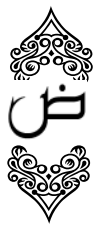

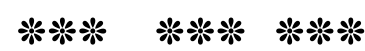

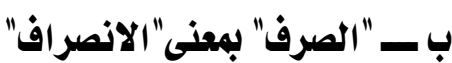

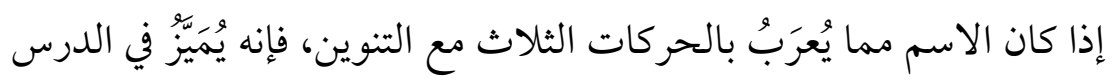

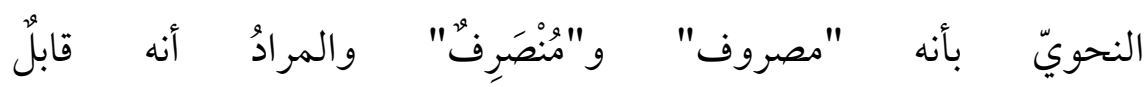
لـ"الصرّف "و"الانصراف"، وسُمِّيَ بـــ(ماينصرف) وما سو اه بـــ(ما لا ينصرف)

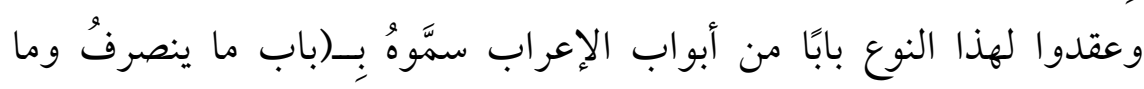

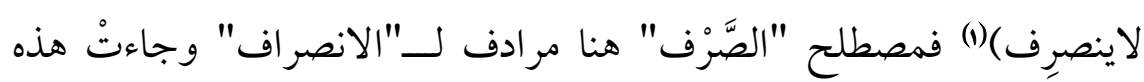
التسميةٌ من قِبَل قبول الكلمة للانتقال من حالٍ مخصوصةٍ إلى أُخرىن، والحال المنتقَلُ إليها هي الإعراب بعلامِّة الجرّ الأصلية، وقبول التنوين مع العلامات

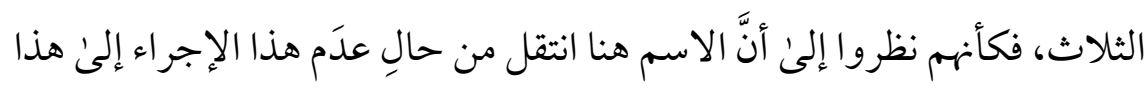

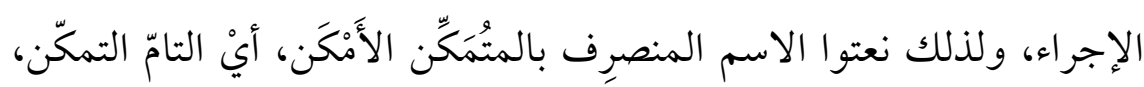

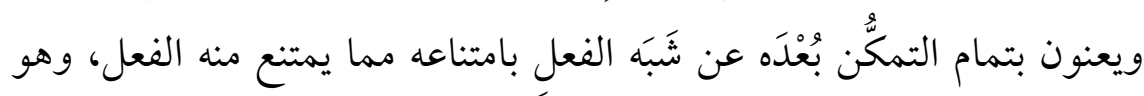

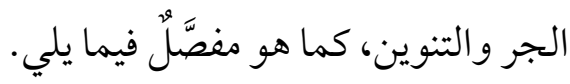

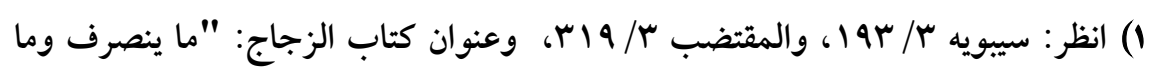

$$
\text { لاينصرف" }
$$




\section{OSC}

قال الخليل رحمه الله: "وصَرْفُ الكلمة: إجر اؤها بالتنوين" (1)، وقال سيبويه:

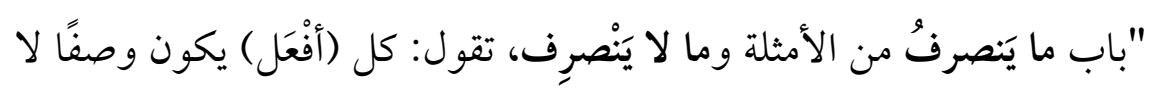
تَصرفه في معرفة ولا نكرة، وكل (أفْعَل) يكون اسمًَ تَصْرِفُهُ في النكرة. قلت فكيف تصرفه وقد قلت: لا تصرفه.."(() فاستعمل "الصرف" مرادفًا لــ"الانصراف"

وقد يُطلقون عليه: "ما يَجْرِي ومالا يَجْرِي" قال المبرد: "هَذَا بَاب مَا يجرىن

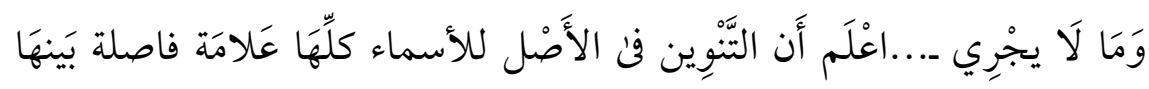

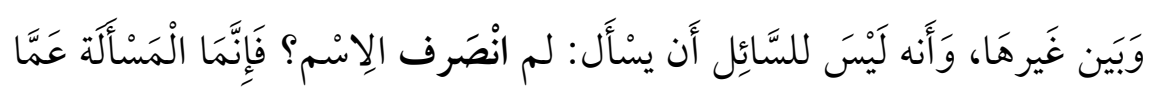

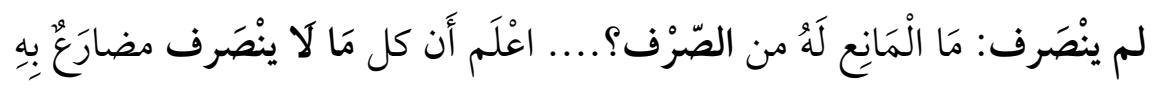

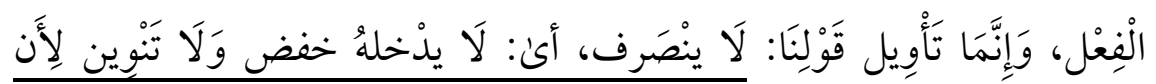

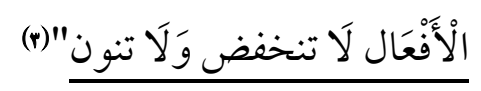

وفسره الزجاج( السه) بالتمام، ثم قال: "ومعنى التمام أن يدخله مع الرفع

والنصب والخفض، ومع الحركات التنوين"(๕) وأوضح ذلك أبو الحسن الباقولي(بـ هــ) فقال:"اعلم أن الأصل في الأسماء الصرف، وذلك لأنها متمكنة، فلتمكنها استحقت الصرف....والمقصود بمنع الصرف إنما هو التنوين

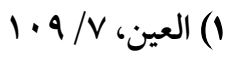

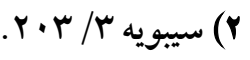

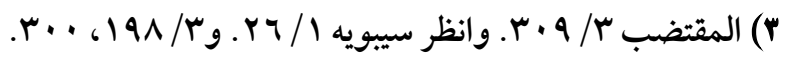

$$
\begin{aligned}
& \text { §) ما لاينصرف، صدץ. }
\end{aligned}
$$


فقط، ولكن إذا لم يدخل التنوين فيما لا ينصرف فإن الجر أيضا لا يدخله تبعًا

$$
\text { للتنوين" (1) }
$$

فإذا اجتمع في الاسم الرفع والنصب والجر والتنوين، دل ذلك على تقلّبّه في

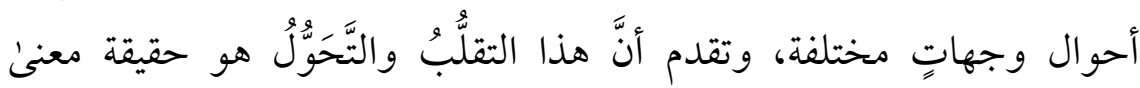

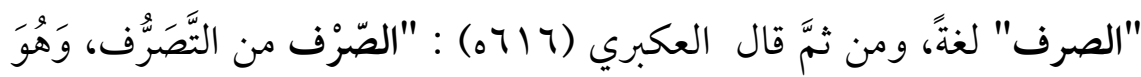

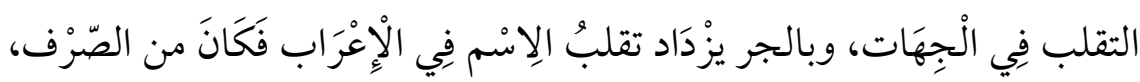

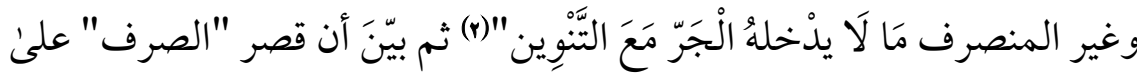
هذا النوع من التقلب والتصرُّف اصطلاحُّ للنحويين، وأما تقلُّب الأفعال

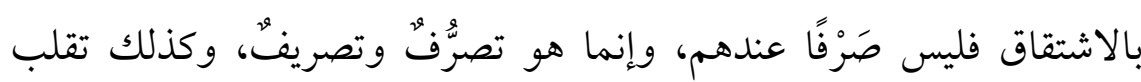

$$
\text { الكلمة بين الرفع والنصب، ليس صَرْفَا(ه). }
$$

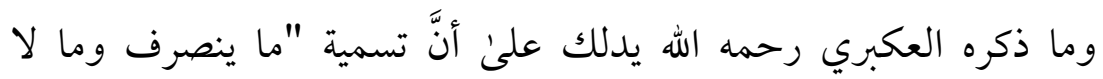

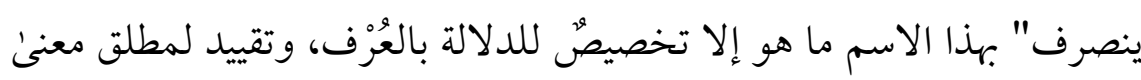
"الصرّف" لأجل ضبط العلم وتحديد قواعده، وهو من تسمية الشيء ببعض مايجري له، أو ببعض سماته أو ما يتصل به، وهو من سنن العربية(8)،وقد تقدم.

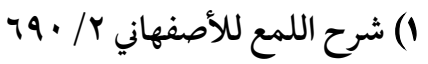

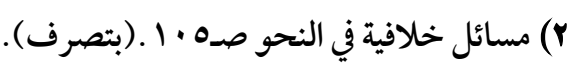
ץ) انظر السابق نفسه.

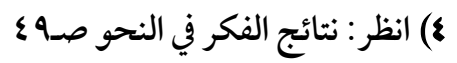




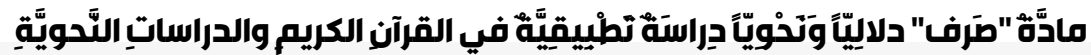

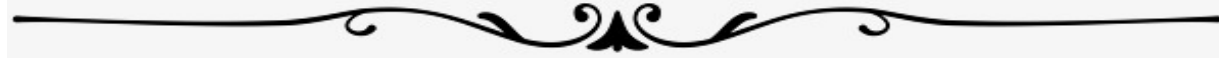

والشاهد من كلامهم أنهم استعملوا مصطلح "الصرف" مرادِفًا لـ"الانصراف"(()وتبعهم النحويون من بعدهم في هذا، غيرَ أن مصطلح "الإجراء" لم يستمر عند المتأخرين، وأنهم اصطحبوا الدلالة اللغوية لهذه المادة؛ فاشتقوا منها هذين المصطلحين المترادفين استعمالًا، فصارَا من امتدادات معانيها، وكان هذا من التطوّر الدلالي لهذه الكلمة على مستوىن

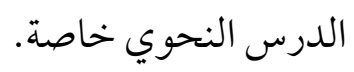

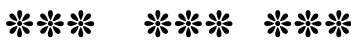

\section{ج - إطلاق "التَّصرُفْ" على عموم التفيير لفظًا ومعنى واستعمالا}

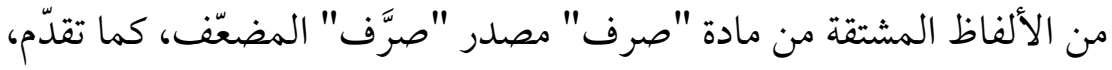
وقد اشتهر عند كثير من دارسي النحو أن المراد بالتصرّف عدم الجمود خاصة، وهو قبول الاشتقاق، أيْ اشتقاق الأبنية من أصلٍ من الأصول، فضيَّقوا الدلالةَ

$$
\text { وحصروها في هذا الإجراء! }
$$

ولكن المطلع في تراث النحو العربي يجد أن "التصرّّف" عند النحويين يطلق على كل تغيير طارئٌ، ولم يخصوا بذلك نوعًا معينًا من التغييرات، فكل كلمة

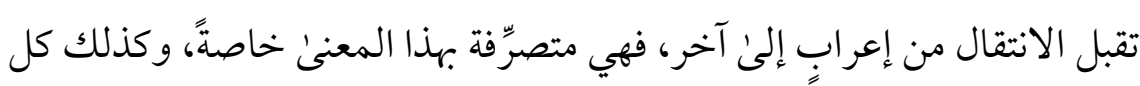
كلمة تقبل الانتقال من وزن إلى آخر، أو تقبل إلحاق اللواصق بها، أو تقبل

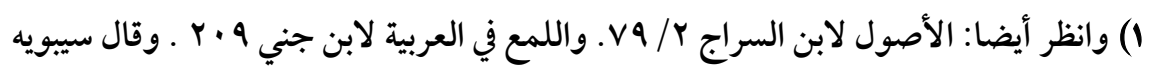

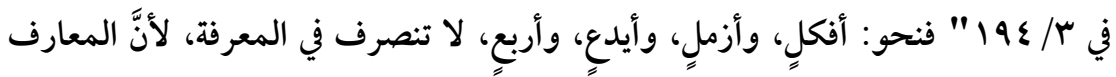

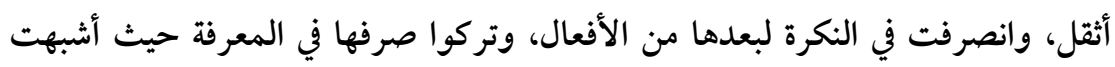

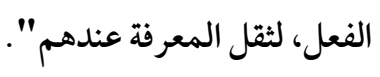


الاشتقاق، أو تقبل الانتقال من معنى إلى آخر، أو يكثر استعمالها قياسًا بنظائرها،

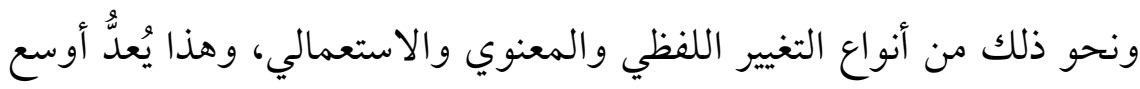
استعمالات فروع مادة "صرف" في الدرس النحوي. وقد تقدمتْ مجموعة من الأمثلة على ذلك في الدراستين: المعجمية، والقرآنية، كإطلاق "صَرْفِ الكلامِ" على التصرُّف فيه بالتغيير والتحسين والتزيين للتأثير (1)، و منه دلالات مشتقات "تصَرّف" المتقدمة في القر آن الكريم. قال سيبويه: " هذا بابُ أيضًا من المصادر يَنتصب، بإضمار الفعل المتروك

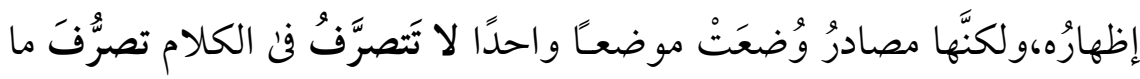

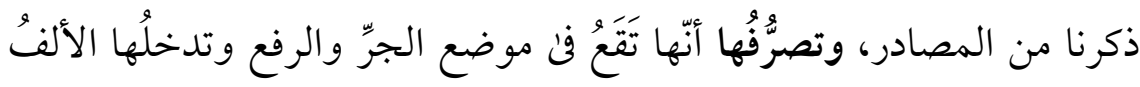

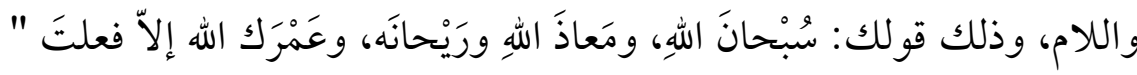

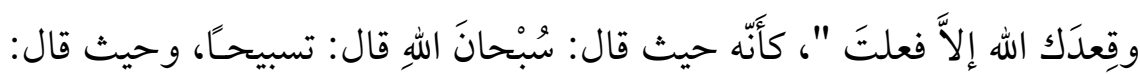

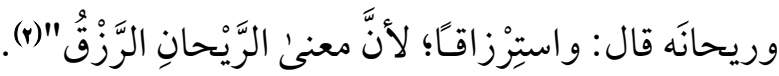

فقد جعل قبول الكلمة لأنواع الإعراب والألف واللام تصَرّفَا، وجعل ما لا لا يقبل منها ذلك غيرَ متصرّف، وهذا مأخوذ من المعنى الجذري لمادة"صرف"

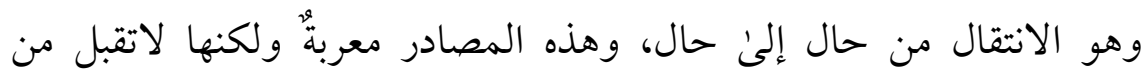
الإعراب إلا النصب، ولاتقبل التنوين ولا الألف واللام، فهي نظير "ما لا ينصرف" المتقدم، في نقصان إعرابها، غير أن "ما لا ينصرف" يدخله نوعان من

1) مقاييس اللغة صـ74. r) سيويه / / TrY. 


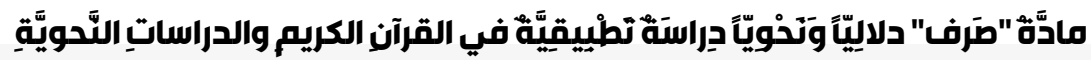

الإعراب: الرفع والنصب، فهو أقوى تصرًُّا من هذه المصادر التي لا تقبل إلا النصب.

وفرَّق أبو سعيد السيرافي(1 ابسه) بين "التصرُّف" و"الانصراف" في كلمة "سَحَرَ" إذا أرددتَ بها سَحَر يومك، فإن ذلك يجعلها عَلَمًا عليها فتعرَّفت بالعلمية، والعدل عن الألف واللام، ثم ذكر أنها غير منصرفة ولا متصرّفة، قال: " فأما قولنا (غير منصرف) فالذي منعه من الصرف أنه معدول عن الألف واللام، وهو معرفة، فاجتمع فيه التعريف والعدل، فلم ينصرف، وأما قولنا: إنه لا يتصرف فمعناه أنه لا يدخله الرفع والجر، وربما دخله الجر، ولا يكون إلا منصوبًا على الظرف، وكذا كل ظرف غير متصرف، فمعناه أنه لا يدخله الرفع الجر، وربما دخله الجر بـ(مِن) فقط من بين حروف الجر"(1) وهذا الذي ذكره السيرافي هو المطرد عند سائر النحويين، وهو استعمالهم لمصطلح "التصرُّف" المطلق، بمعنى قبول جميع أنواع التغييرات، وعدم "التصرُّف" بمعنى نقصان الكلمة عن سائر بنات جنسها في قبول التغييرات، ولذلك نجدهم يقولون في نحو: "عند، ولدئ، ودون، وذات مرة، ويكرة، وعشية..."وأمثالها إنها ظروف غير متصرّفة؛ لأنها لا تقبل من الإعراب إلا النصب، والجرّ بـ(مِنْ) خاصة(ه)، ولذلك قال المرادي(9 ع Vه):" و وإنما يثبت

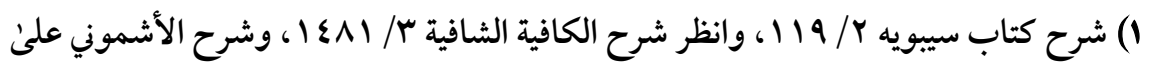

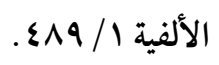

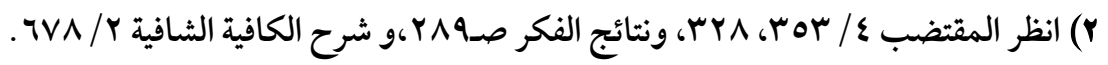




\section{مجلة كلية اللغة العربية بالمنوفية العدد الذامس والثلاثون - إصدار ديسمبر 2020م}

9人e

تصرف الظرف بالإخبار عنه والجر بغير (مِن) ـ في الاختيارِ-لأن (مِن) كثرت

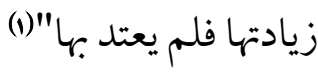

وكل ما دلَّ على مكانٍ أو زمانٍ فهو ظرف، ولكن ما قد يفارق الظرفية منه

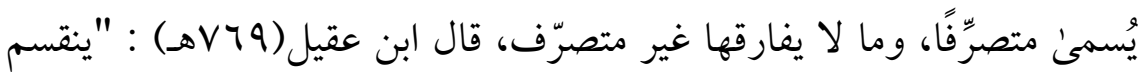
اسم الزمان واسم المكان إلىي: متصرف وغير متصرف فالمتصرف من ظرف الزمان أو المكان: ما استعمل ظرفًا وغير ظرف كـ"يوم" و"مكان" (r)

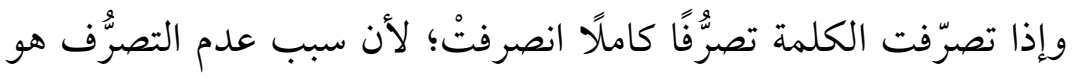

$$
\text { الذي أدى إلى عدم الصرف(+). }
$$

ونصَّ سيبويه على أن "حَنانَيْك" وبابه ـ كسعديك ولبيك ... _ لا يتصرف، كما لم يتصرَّف "سبحان" وبابه(8)، وشرحه السيرافي فقال: "وهذا المشنى كله غير متصرف، ومعنى قولنا (غير متصرف) أن لا يكونُ إلا مصدرًا منصوبًا أو اسمًا في موضع الحال... فلم يتصرّفوا فيه وبعضه يوَحسد فيتصرّف(ه)، كما قال تعالى : التصرف جاء مِن قِبَلِ كونه ملازمًا للتثنية، فجعلوا لزومه لبناء المشنى عدم

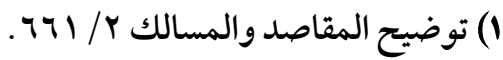

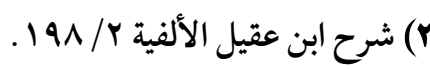

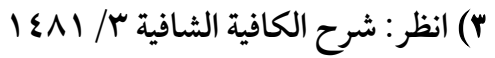

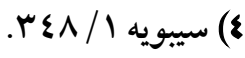

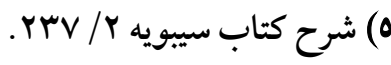

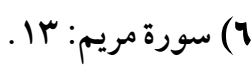




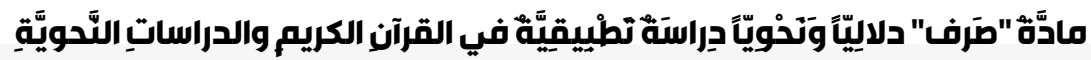

تصرُّف، كما جعلوا لزوم (سبحانَ) وبابه للنصب عدمَ تصرّف، فدل ذلك على

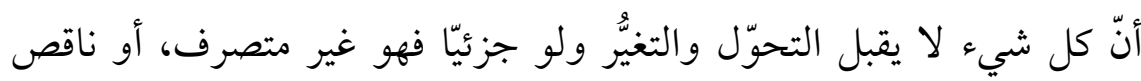
التصرف.

وأوْرَدَ أيْضًا أخوات"ظنَّ" فقال: "هي ظنتت، وحَسِبتُ، وخِلتُ، وأُرِيتُ ورأَيتُ، وزعمتُ، وما يتصرفّ من أفعالهن "(1) يريد بــ(ما تصرَّف منهن) أسماء الفاعلين والمفعولين والمصادر والمضارع والأمر، وسائر المشتقات، فسمى ئن

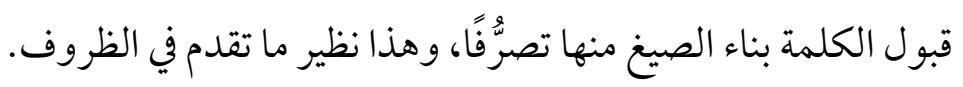
وذكر في (رُوَيْدَ) و(دونَ) أنهما غير متصرِّفتين (r)؛ لأنهما لا تضافان إلا إلىن مخاطب، يقال: رُوَيدَكَ زيدًا، ودونك عَمْرًا، ولا يُقال: رويدَه، و لا دونَه، فهذا هو

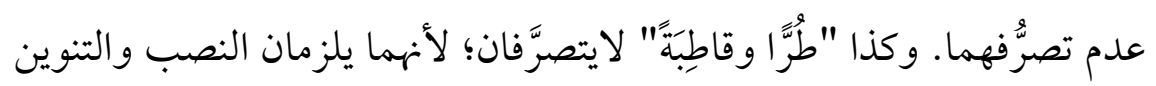

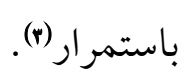

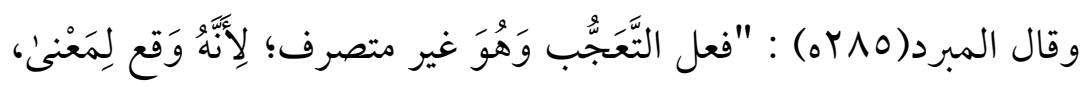

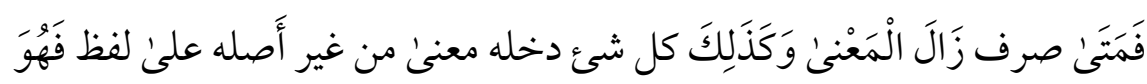

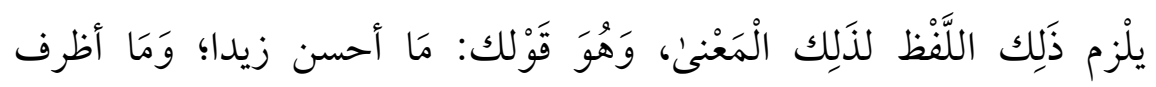
أَخَاك..."(8) وزاد ذلك إيضاحًا فقال: " كل مَا لزمَهَ شَيْء على معنى لم يتَصَرَّف

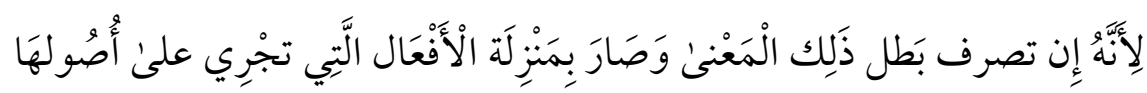

$$
\begin{aligned}
& \text { 1) سيبويه /111. } \\
& \text { r) انظر سيبويه / / • P. } \\
& \text { ץ) انظر سيبويه / TVT. } \\
& \text { 8) المقتضب r// 19 19. }
\end{aligned}
$$


وَلم يدخلهَا من الْمَنْنى أَكثر من ذَلِك "(1) يريد بهذا نحو "أفعل "في التعجب، فإنه

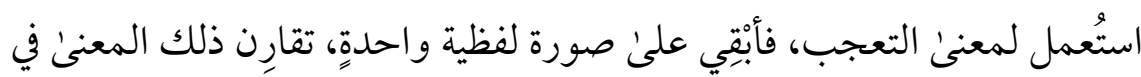
أسلوبه المصطلح عليه، فصار بذلك غير متصرّف (r).

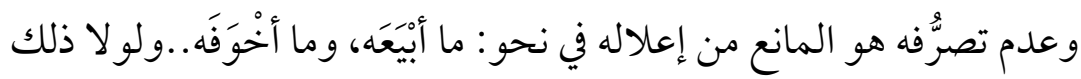
لقيل: ما أباعه وما أخافه(؟). وذكر أن عامل الحال إن كان غير فعْلٍ فإن الحال لاتتقدم عليه، فلا يقال

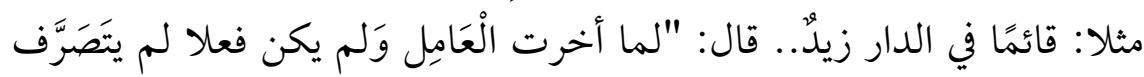
تصرف الْفِعْل فينصب مَا قبله"(() فأفاد أن عمل الفعل متقدمًا ومتوسطًا ومتأخرًا تصَرُّفُ، وكل عامل لا يعمل متقدمًا فإنه غير متصرٍِِّ، وكذا يُقال في كل ما جاز التصرف فيه بالتقديم والتأخير ونحوهماه(، فدل ذلك أن مطلق قبول التغيير في

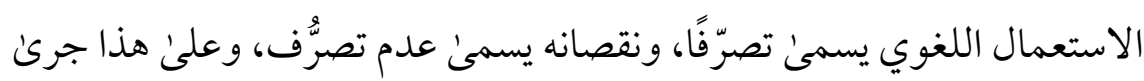
النحويون من بعدهم.

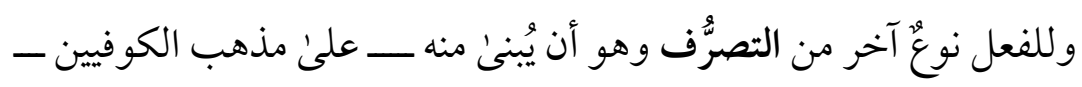
الماضي والمستقبل، واسم الفاعل، واسم المفعول....وسائر المشتقات(؟).

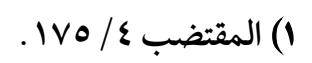$$
\text { \$) انظر أيضا: الأصول في النحو لابن السراج / }
$$

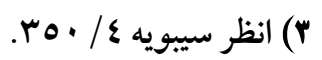

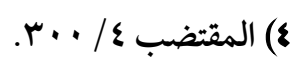

0) انظر: الخصائص // דr

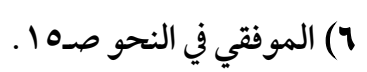




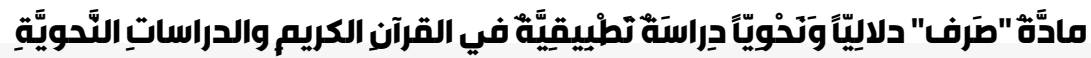

\section{$\longrightarrow$ C OSC}

وذكر ابن كيسان أقسام معاني الكلام، ثم قال: "والخبرّ أكثرُها تَصَرَّفًا"(() يريد

أن الخبرَ أكثر دورانًا واستعمالا في اللغة من الدعاء والاستخبار والطلب(الأمر

$$
\text { والنهي) فسمى كثرة الاستعمال تصرُّفًا. }
$$

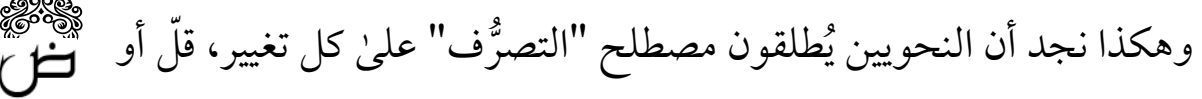

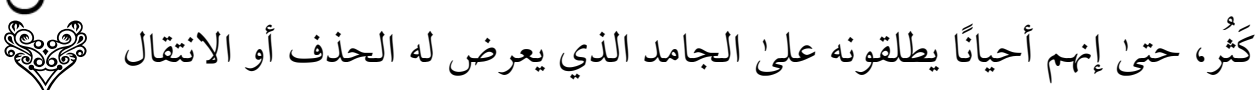

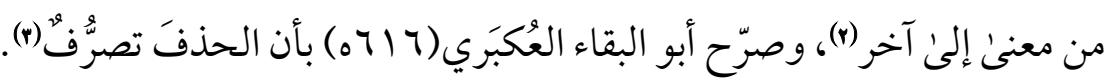

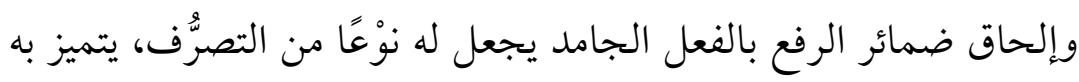

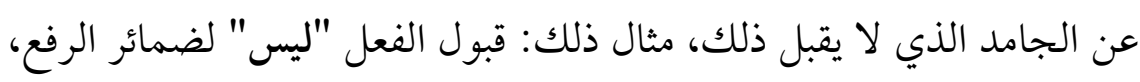

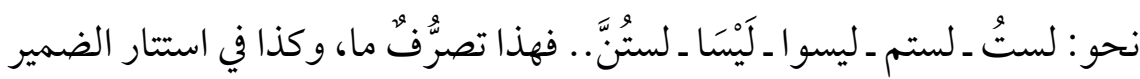
فيه إذا قلتَ: "زيدُ ليس مسافرًا" وفي امتناعه من اشتقاق المضارع والأمر وسائر

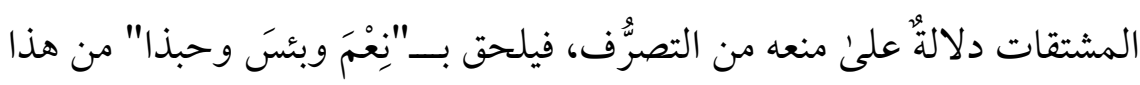
الوجه (8)، وإنما سُمي ذلك تصرُّفًا لأنه يُعد انتقالا من صورةٍ إلىن أخرىن، وتَغَيُّرًا

$$
\text { من شَكْلٍ إلىن آخر . }
$$

وقد أشار ابن جني إلى أن امتناعهم من التصرّف في هذه الأفعال الجامدة الحكمة فيه راجعة إلى المعنى، وذلك أنهم أراد المبالغة في تأكيد معاني هذه

$$
\begin{aligned}
& \text { () الموفتي في النحو صـ9. } \\
& \text { r) انظر المغني صدדr. }
\end{aligned}
$$

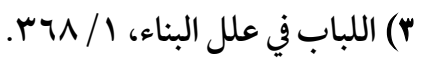

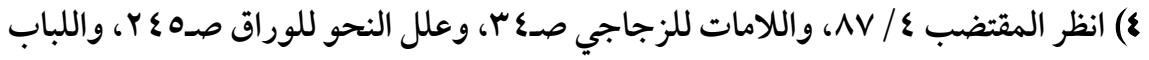

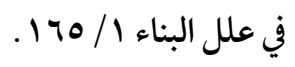


الأفعال وتثبيتها، وقصدوا إلى الشدةِ في طلب دلالاتها(1)، وهذا يدل على أن

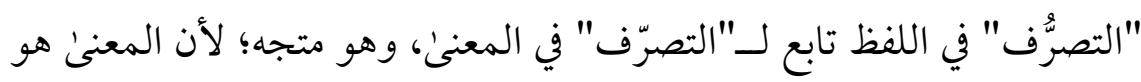

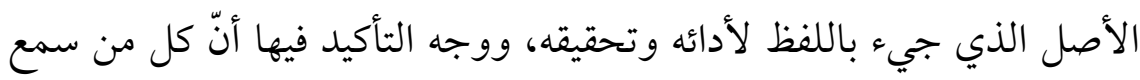

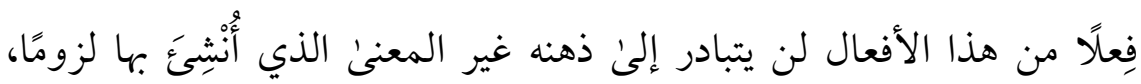

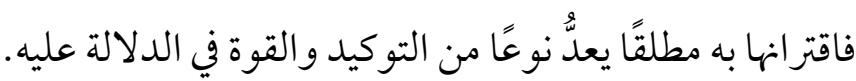

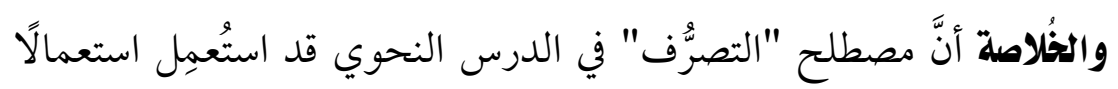

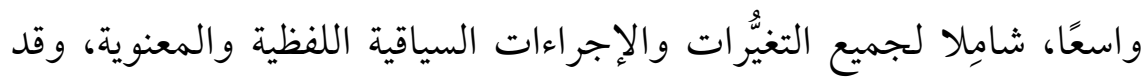
تجاوز "التصريف" و"الاشتقاق" فاستعمل فيهما وفي غيرهما((r)، و"عدم

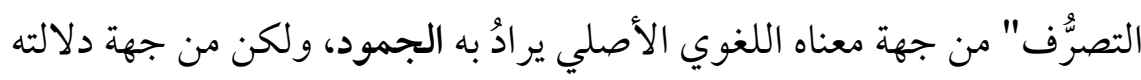

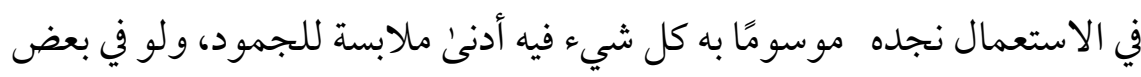
استعمالاته، أو بعض جهاتِ وروده (r)كما ورد في الأمثلة والنقول المتقدمة.

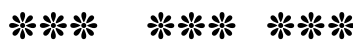

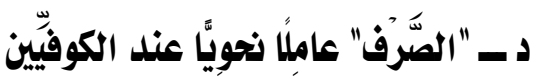

ذهب جمهور الكوفيين إلىن إطلاق كلمة "الصَّرْف" مصطلَحًا نحوِيَّا على الني عامل النصب في الفعل المضارع المعطوف في سياق طلٍ أوْ نفي، مصطحبين

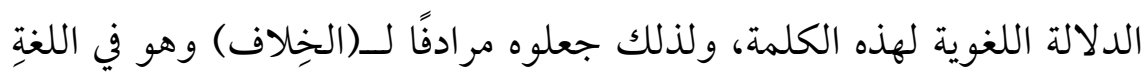

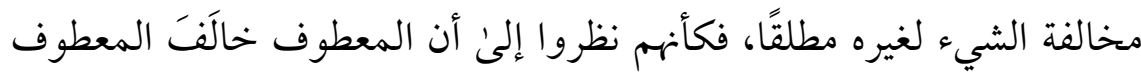

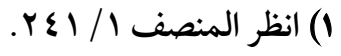

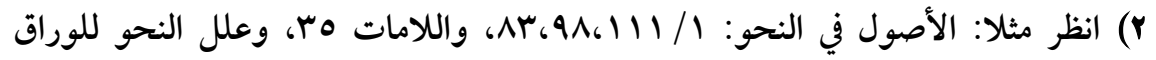

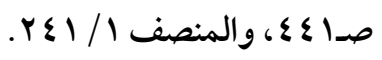

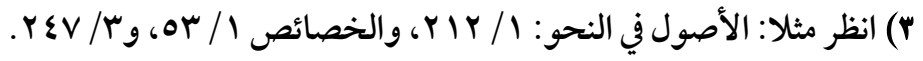




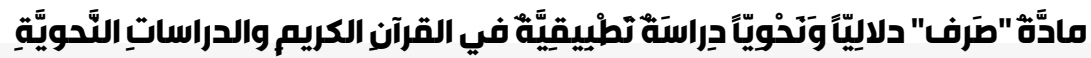

علهه في المعنى'، و انصرَف عنه، فجعلوا هذا الانصر اف علامةً موجبةً للنصب، وسمَّوْه "صَرْفًا"، ويكون ذلك بعد واو المعية وفاء السببية وأَوْ وثُمَّه، وأما البصريون فيرون أنَّ النصب حاصل بـ(أنْ) المضمرة بعد هذه الحروف، نحو:

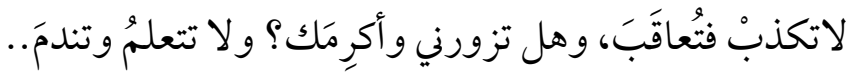

وقد تكررت هذه التسمية في كتبهم في تعليل هذا النوع من النصب، وشرحوه

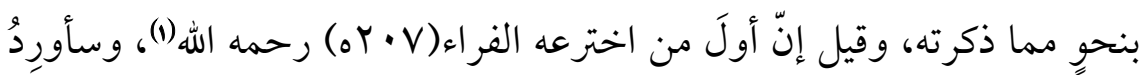
طائفةً من أقو الهم في تفسيره و إطلاقه للتدليل على' ذلك:

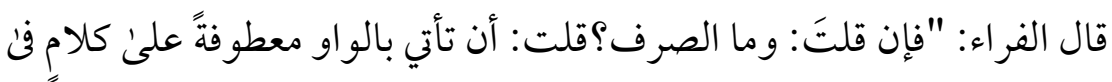
أوّله حادثة لا تستقيم إعادتها على ما عُطِف عليها، فإذا كان كذلك فهو الصَّرْفُ،

\section{كقول الشاعر}

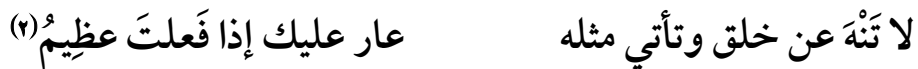

ألا ترى أنه لا يجوز إعادة (لا) فِي (تأتي مثله) فلذلك سُمّي صَرْفًا إذْ كان

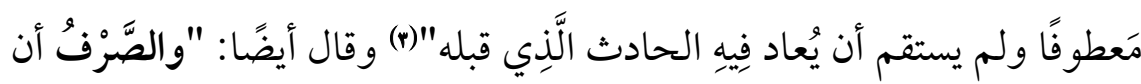

$$
\text { 1) انظر مصطلحات النحو الكوفي صده • 1 -9 • 1. }
$$

ץ) بيت من الكامل، نُسب لعدة شعراء، منهم أبو الأسود الدؤلي، وحسان، والأخطل، والمتوكل الليثي، وسابق البربري، وغيرهم، انظر: ديوان سابق صده ال، وسيبويه س/ Yع،

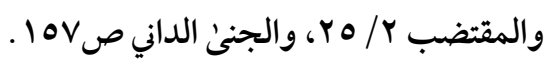

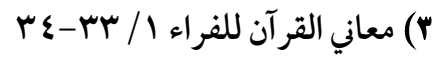




\section{مجلة كلية اللغة العربية بالمنوفية العدد الذامس والثلاثون - إصدار ديسمبر 2020م}

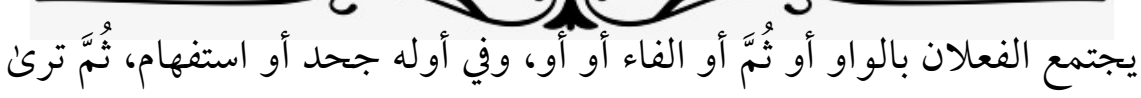

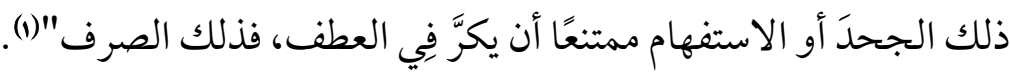

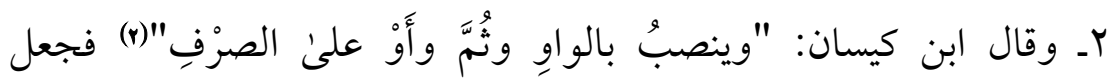
"الصرف" سبيًا للنصب بعد حروف العطف، وجعل حرف العطف هو الناصب،

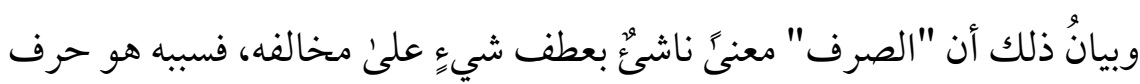
العطف، فصار النصب مُسَبَّا عن العاطف الذي هو سبب الصرف، فاتجه لذلك

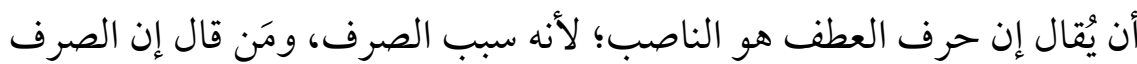

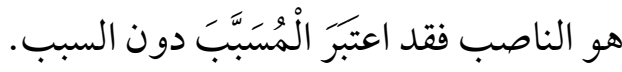

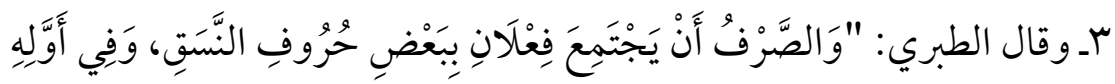

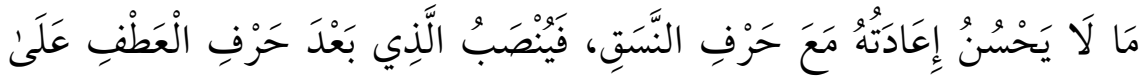

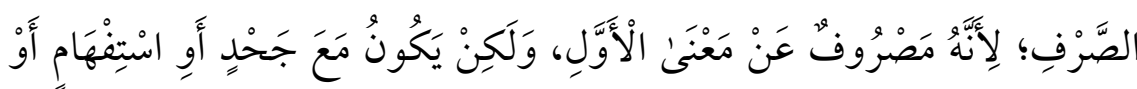

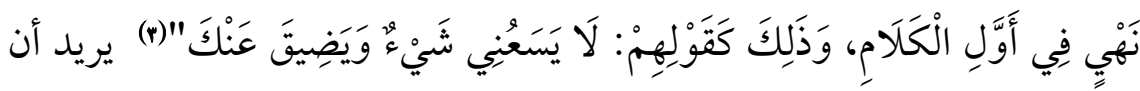
معنى "لا يسعني" النفي. ومعنى " ويضيق عنك" الإثبات، فقد انصرَف معنى لئن

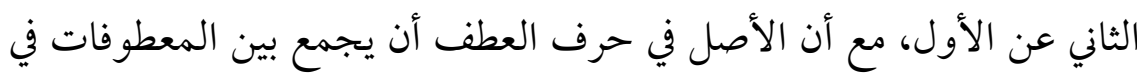

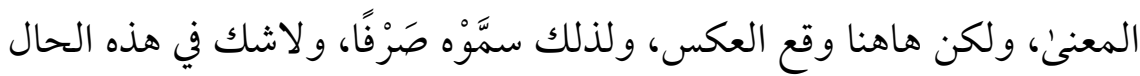

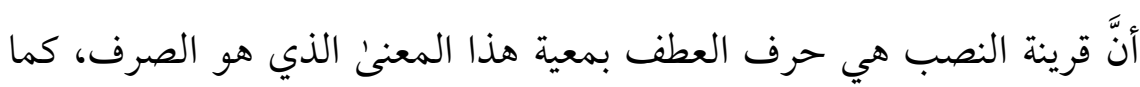
يفهم من كلام ابن كيسان المتقدم.

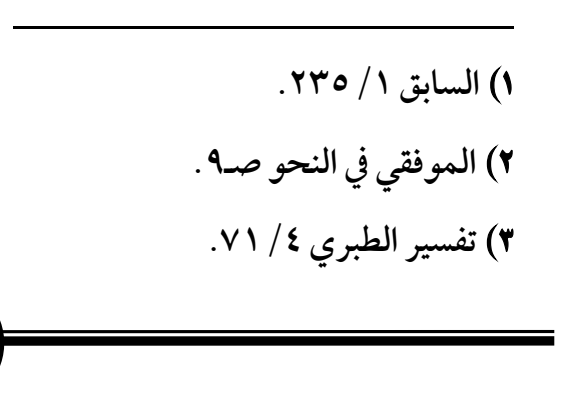




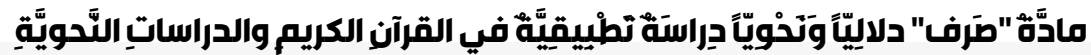

\section{عـ وقال ابن السراج: " وهذا النصب يسميهِ الكوفيونَ الصرف؛ لأنَّهم صرفوه} عن النسقِ إلى معنى غيره"(() ونصَّ على مثل ذلك معاصره أبو إسحاق

$$
\text { الزجاج(*)، وكذلك أبو منصور الأزهري((). }
$$

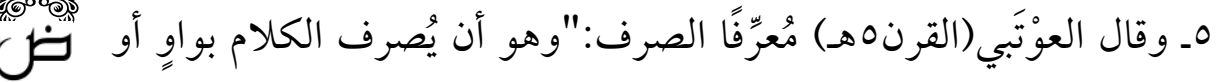
فاءِ أو ثَُّّم عن وجه النسَق والجواب فينصب الفعل"(8) هكذا أطلقوا هذا المصطلح بهذا المفهوم، وهو بهذا خاصٌّ بالتركيب، وحكمٍ من أحكامه الإعرابية. ولا ريب أنَّ هذا نوعُ من تخصيص الدلالة ـ أيضًا ــوهو إطلاق هذه الكلمة على بعضٍ مما يصدق على معناها اللغوي المركزي العام، فالكلمة التي أُريدَ بها

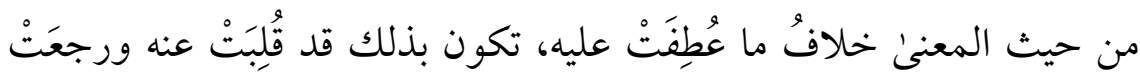

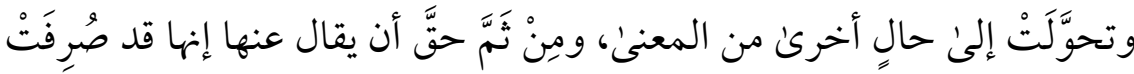
عما قبلها؛ لأن هذا هو حقيقة معنى "الصرف" كما تقدم.

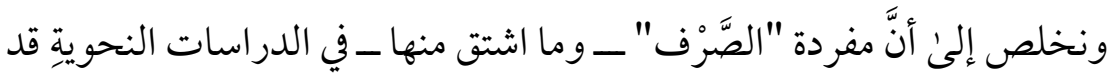
تُوسِع فيها، وامتدّتْ دلالاتها على المستوىن اللغوي الخاص، وعلى المستويات التطبيقية والنظرية، فُججعَِت منها مصطلحاتُ لأنواع من الإجراءات الدراسية على مستوىن المفردات وعلىن مستوئ التركيب وما يتصل بهما، في إطار الوصف

$$
\begin{aligned}
& \text { 1) الأصول في النحو / 1199. }
\end{aligned}
$$

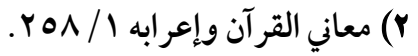

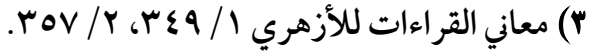

$$
\begin{aligned}
& \text { \&) الإبانة في اللغة العربية للعوتبي ـ/ اهـ (بتصرف يسير ) }
\end{aligned}
$$




\section{مجلة كلية اللغة العربية بالمنوفية العدد الخامس والثلاثون - إصدار ديسمبر 2020م}

\section{ग19}

النحوي الشامل، واستُعملت على مستوكن بالغ الدقة مصطلحًا لا يحدده إلا

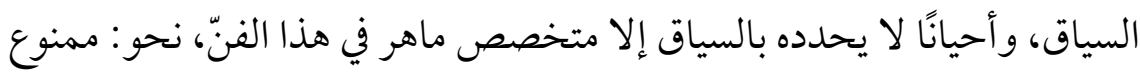

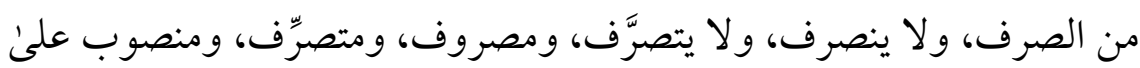
الصرف، وليس من التصريف، وجزء من التصريف، وهو منصرف، وهذا صَرْفُ....ونحو ذلك مما تقدم. ومرّ بنا أيضًا أن مصطلح "الصرْف" ومشتقاته في الدراسات النحوية قد أُطلقِق في الكلمات المفردة، والكلام المركب، والأجزاء الصوتية، والجمل التامة، وفي

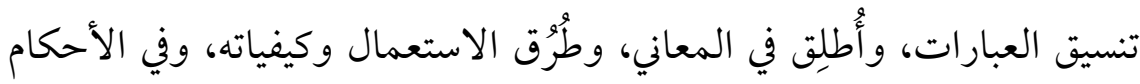
الإعرابية، والأزمنة، والأبنية، والحذف، والزيادة، ونحو ذلك.

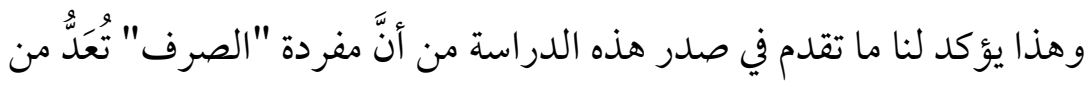

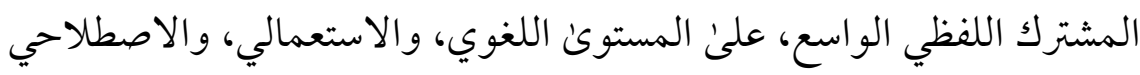

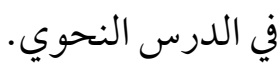

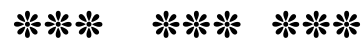




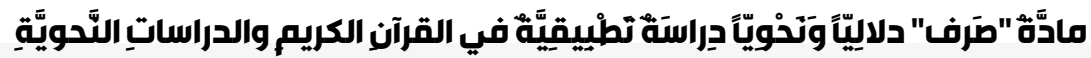

\section{خاهساً: الخاتمة والنتانجه}

تتبعت هذه الدراسة مادة "صَرف" اللغوية، فاستقصتْ دلالتها في التراث العربي، ووقفت على امتداداتها الدلالية، وتناولَتْ استعمالاتها عند العرب، تلان

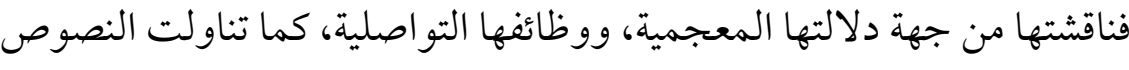

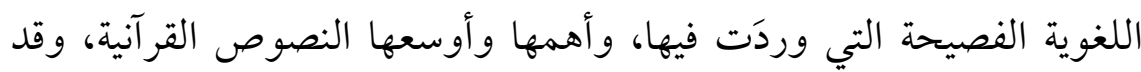
أحصتْ الدراسة مواطن ورودها فيها، وناقشت دلالاتها بما قارنها من الأساليب،

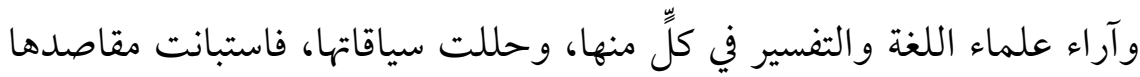

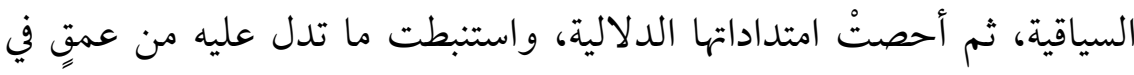

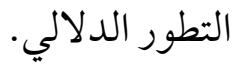

ثم جنحت الدراسة في ثلثها الأخير إلى دلالة هذه المادة في الدراسات

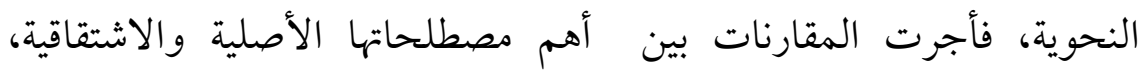

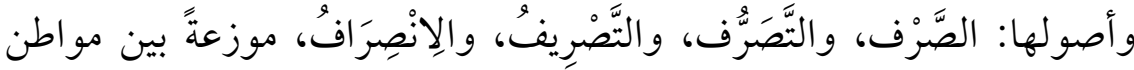
استعمالها ودلالاتها في الدرس النحوي، على مستوئ المفردات، والتراكيب،

$$
\text { والمعاني الاصطلاحية. }
$$

ولم تُغفل الدراسة التنبيه على الاستعمالات الدلالية لهذه المادة عند الدادئ المحدثين، في الاستعمالات اللغوية بعامة، المعجمية، والتواصلية، والنظرية و التطبيقية، وعلئ مستوئ الأفراد، وحركة التأليف والتعليم في العالم العربي.

\section{ثر خلصت اللدراسة إلى الاستنتاجات التالية:}

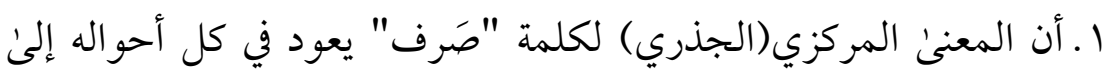

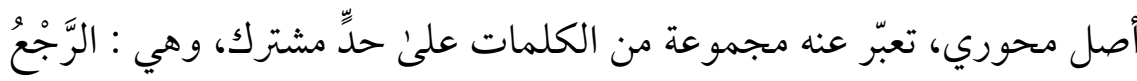




\section{مجلة كلية اللغة العربية بالمنوفية العدد الخامس والثلاثون - إصدار ديسمبر 2020م}

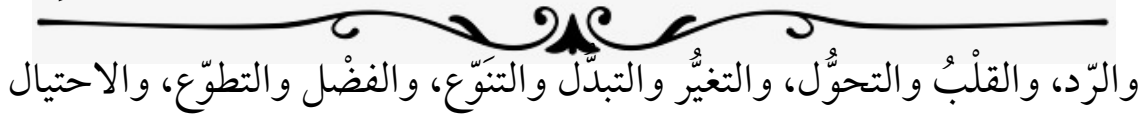
والتكلف، ونجد أنَّأغلب استعمالاتها ترجع إلىن هذه المعاني من قريب أو بعيد.

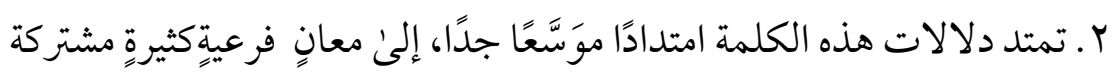
في الأصل السابق كلها وترجع إليه عند التأمل، وقد أحصتٌ منها الدراسة ما يزيد عن ثمانين معنَّى، سبعة وستون منها معانٍ سياقية في القر آن الكريم. r. خلصت الدراسة إلى أن مصطلح "الصرّف" ومشتقاته في الدراسات النحوية قد أُطلقَِ في الكلمات المفردة، والكلام المركب، والأجزاء الصوتية، والجمل التامة، وفي تنسيق العبارات، وأُطلقِق في المعاني، وطُرُق الاستعمال وكيفياته، وفي الأحكام الإعرابية، والأزمنة، والأبنية، والحذف، والزيادة.

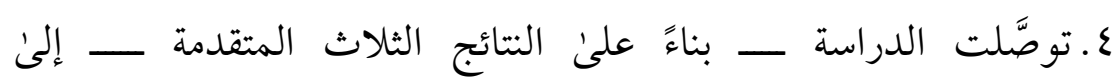
كلمة"صرف" من المشترك اللفظي، وأنها من أثرى مو اد المشترك اللفظي. ه. كشفت الدراسة أن كلمة "صرف" تدرجت دلالتها اللغوية متطورةً، فابتدأت بمعانيها المعجمية التي وردت في كلام العرب، ونص عليها علماء اللغة في المعاجم اللغوية، وعلى رأسها "معجم العين" ثم توسعت هذه الدلالات في

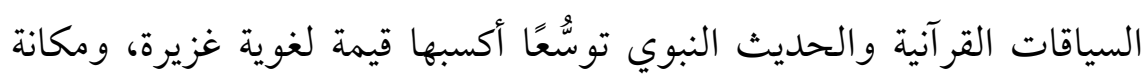
بارزة في التعبير، ثم ازدادت توسعًا عند علماء النحو، حين جعلوا منها مصطلحات لأقسام علمية معينة من المعالجات النحوية على مستوئ المفردات الصرفية، والجمل النحوية، والإعراب، والوصف النحوي بعامة، وتبع ذلك كله توسعها المستمر إلى يومنا هذا في غالبية مجالات الحياة، بما يستعصي إحصاؤه على دارس. 


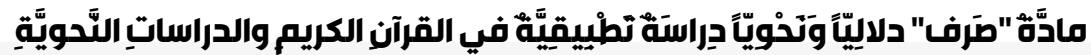

\section{$\longrightarrow$ Casc}

7. مما أفادته كلمة "صرف" من انتمائها إلى المعجم العربي هذا التوسع الدلالي العجيب، الذي جاء من طبيعة مرونة اللغة العربية وقوتها في الاشتقاق و المجاز والكناية، ومِن ثَََّّ وجدنا الكلمة تدل على أشياء كثيرة ليس بين معناها الأصلي وبينها إلا ملابسات يسيرة، أو طَرَفٍ من خيط شديد الدقة! V. وجدت الدراسة أنّ دلالة اللفظ قد تمثد بسبب تنويع الأسلوب، وتعدد الغرض، مثل: "صرّف الكلام" بمعنى تزيين أسلوبه والتنميق فيه حتى يصرف

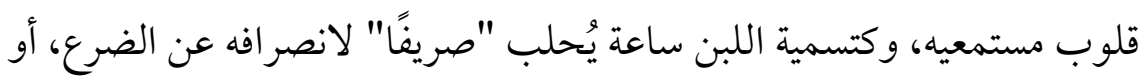
انصر اف الرغوة عنه، فالغرض الدلالة على جِدَّته. ^. استتجت الدراسة أن مصطلحات "الصرف، والتصريف، والتصرّف، والانصر اف" اشتركت في دلالاتها الاستعمالية اللغوية والنحوية، كما اشتركت في الاشتقاق، ويعني ذلك أن استعمالها كلها من أصلٍ لفظي واحدِ يوحي بارتباط المعاني المصطلحية بها ارتباطًا وثيقًا، وأن ذلك له أثر كبير في فهمها وربط لهُ معالجاتها النحوية المستعملة ببعضها. 9. ليس مصطلح "التصرُّف" في الدراسات الصرفية والنحوية خاصّا بعدم الجمود، بل قد استُعمل لمطلق التغيير، ولو كان التغيير يسيرًا، ولذلك انتهت

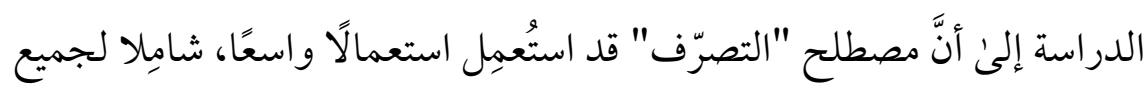
التغيُرات والإجراءات السياقية اللفظية والمعنوية، وقد تجاوز "التصريف" و"الاشتقاق" فاستُعمل فيهما وفي غيرهما، و"عدم التصرُّف" من جهة معناه اللغوي الأصلي يرادُ به الجمود، ولكن من جهة دلالته في الاستعمال نجده موسومًا به كل شيء فيه أدنى ملابسة للجمود، ولو في بعض استعمالاته، أو بعض جهاتِ وروده. 


\section{مجلة كلية اللغة العربية بالمنوفية العدد الخامس والثلاثون - إصدار ديسمبر 2020م}

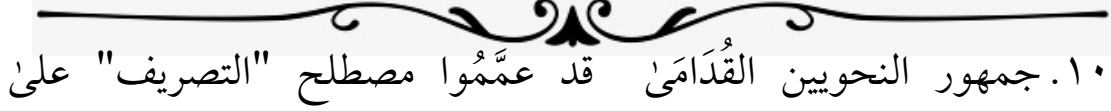

المباحث الصرفية، وإن كان بعضهم قد خصَّ به الجانب العملي(التدريبي) وبعضهم جعله مع ذلك لِما كان التغيير فيه لتوليد المعاني فقط، أما المخْدثون

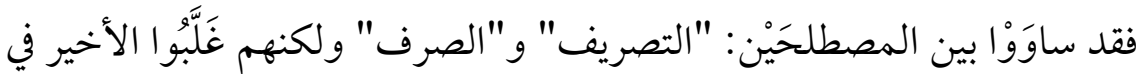
استعمالهم وتأليفهم؛ لعموم معناه اللغوي. الـان بعض قدامى النحويين يسمون إعراب الاسم بالجر والتنوين: "الإجراء" ويقولون: "ما يجري وما لايجري" بدلًا من "ما ينصرف وما لا ينصرف" ثم استمر هذا الأخير، واختفى الأول عند المتأخرين، واستعملوا

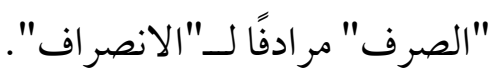

r ا ـ رأت الدراسة بعد استعراض الآراء والأدلة أن تخصيص "ما ينصرف وما لا ينصرف" هذا الاسم ما هو إلا تخصيصٌ للدلالة بالعُرْف، وتقييد لمطلق معنى "الصرّف" لأجل ضبط العلم وتحديد قواعده، وهو من تسمية الشيء ببعض مايجري له، أو ببعض سماته أو ما يتصل به، وهو من سنن العربية. سا ـ خلصت الدراسة أيضا إلى أن اصطلاح الكوفيين على تسميتهم لنصب المضارع بعد حروف العطف في سياق نفي أو طلب: "صرْفًا" يُعَدُّ نوعًا من تخصيص الدلالة، وهو إطلاق هذه الكلمة على بعضٍٍ مما يصدق على معناها

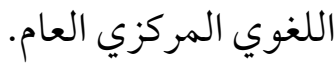
والقّ أُحلد. 


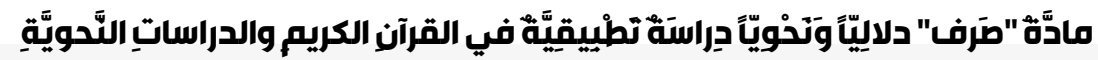

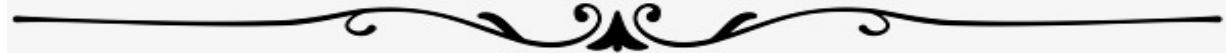

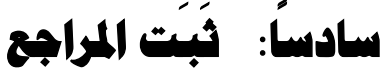

ا ـالإبانة في اللغة العربية، لسلمة العوتبي،حققه مجموعة من المحققين،

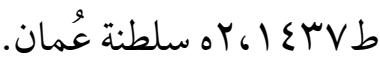

$$
\text { أدب الكاتب بشرح البطليوسي =الاقتضاب. }
$$

r. ارتشاف الضرب من لسان العرب ، لأبي حيان الأندلسي ، تحقيق مصطفئ النماس،ط | ، ع • ع أهـ مطبعة النسر الذهبي .

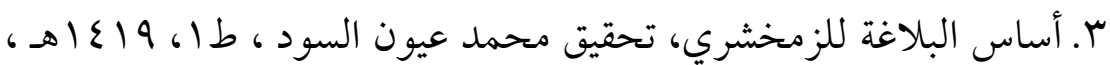

$$
\text { دار الكتب العلمية ، بيروت }
$$

ع. الأسس الإبستمولوجية والتداولية للنظر النحوي عند سيبويه، لإدريس

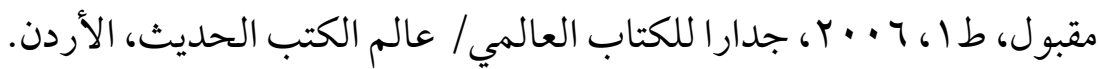

ه. إسفار الصباح عن ضوء المصباح، لابن النحوية، تحقيق: إبراهيم الزيد،

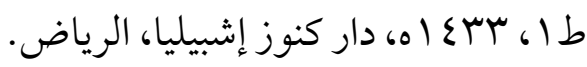

$$
\text { أشعار الهذليين للسكري = شرح أشعار الهذليين. }
$$

7.الأصول في النحو لابن السراج،تحقيق عبد لحسين الفتلي، طال،

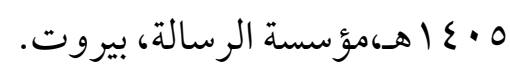

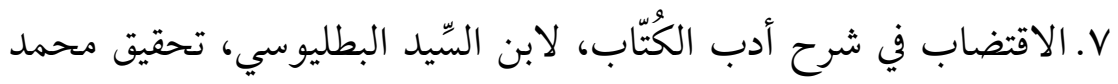

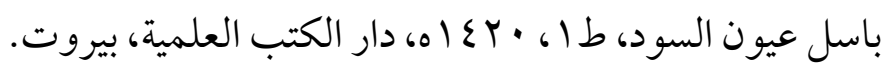

^. البحر المحيط في التفسير لأبي حيان الأندلسي، بعناية زهير جعيد ، ط/

$$
\text { المكتبة التجارية بمكة المكرمة . }
$$

9 ـ البرهان في علوم القرآن للزركشي،تحقيق محمد أبو الفضل، دار المعرفة ، 
• ا. التتمة في التصريف،لابن القبيصي،تحقيق:محسن العميري،طا، ع ع ع إد/ نادي مكة الأدبي. 11 ا. التحرير والتنوير لابن عاشر، ط9 /99 ادار سحنون، تونس.

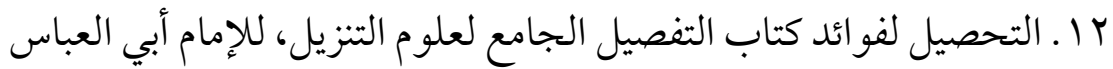

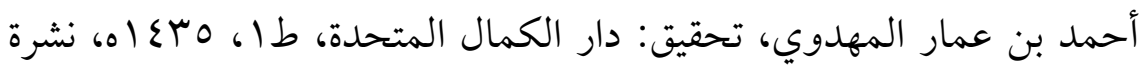

$$
\text { وزارة الأوقاف بدولة قطر. }
$$

rا ـ التطبيق الصرفي لعبده الراجحي، لعبده الراجحي، ط/ دار النهضة العربية،

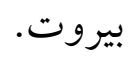

ع ا. التعريفات للجرجاني ، تحقيق محمد المرعشلي ط ا، عبعاهـ دار

$$
\begin{aligned}
& \text { النفائس ، بيروت } \\
& \text { تفسير الرازي = تفسير الفخر الرازي }
\end{aligned}
$$

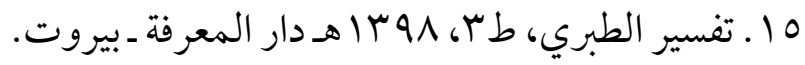

$$
\begin{aligned}
& 17 \text { ا. تفسير الفخر الرازي(التفسير الكبير ـ مفاتيح الغيب) للإمام فخر الدين }
\end{aligned}
$$

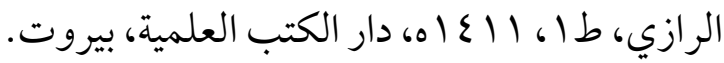

$$
\begin{aligned}
& \text { تفسير القرطبي = الجامع لأحكام القرآن } \\
& \text { التفسير الكبير = تفسير الفخر الرازي }
\end{aligned}
$$

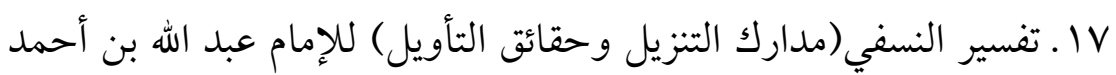

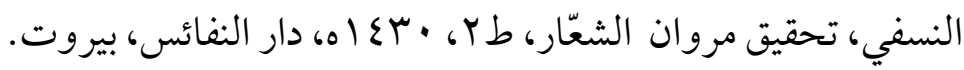

1 ا. تمهيد القواعد بشرح تسهيل الفوائد، لمحب الدين محمد المعروف

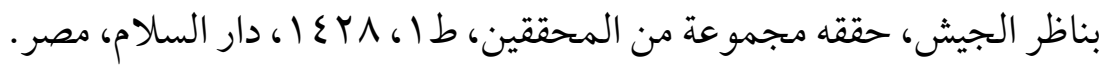

19. تهذيب الكمال في أسماء الرجال للحافظ المِّزي، تحقيق بشار عواد

$$
\text { معروف، ط |، 1 • ع اهـ مؤسسة الرسالة، بيروت. }
$$




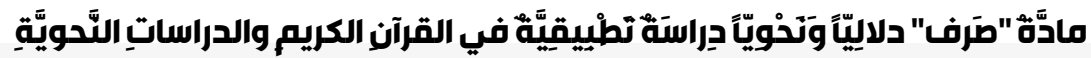

·r.r. تهذيب اللغة للأزهري، تحقيق عبد السلام محمد هارون، طا ، 97سام مكتبة الخانجي بالقاهرة

ا ا. توضيح المقاصد و المسالك، لابن أم قاسم المرادي، تحقيق عبد الرحمن سليمان، ط ب، مكتبة الكليات الأزهرية، مصر.

r r. جامع الدروس العربية للغلاييني، للشيخ مخصطفى الغلاييني، طا،

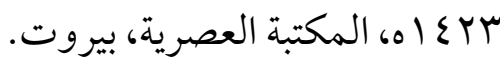

بr. الجامع لأحكام القرآن لمحمد الأنصاري القرطبي،دار إحياء التراث

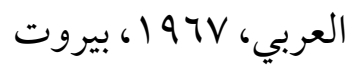

ع ז. جمهرة اللغة لابن دريد، تحقيق رمزي منير بعلبكي، طا، 9191 ام دار

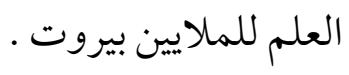

هو. الجنى الداني للمرادي، تحقيق فخر الدين قباوة ومحمد نديم ، طل،

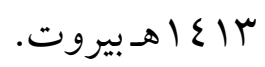

جr. الحدود للرماني: رسالتان في اللغة، لأبي الحسن الرماني، تحقيق: إبراهيم

$$
\text { السمرائي، ط/ عـ9 اله، دار الفكر، الآردن. }
$$

YV حروف المعاني للزجاجي،تحقيق: علي توفيق ، ط Y، 7 + ع (ه، مؤسسة

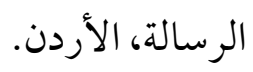

AY. الخصائص لابن جني ، تحقيق محمد علي النجار ، دار الكتاب العربي -

$$
\text { بيروت. }
$$

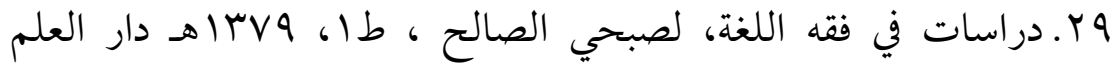

$$
\text { للمالايين ، بيروت . لمان. }
$$

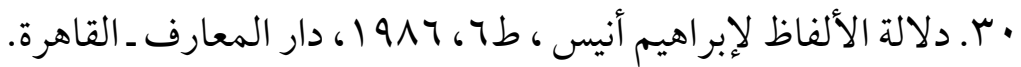
آم.ديوان الأدب ميزان اللغة ومعيار الكلام، لإسحاق بن إبراهيم الفارابي، 


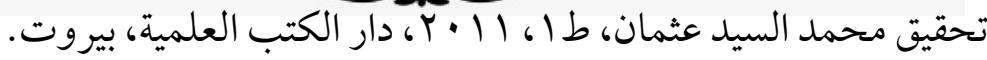

r r. ديوان النابغة الذبياني: تحقيق شكري فيصل. ط ط، · اع اه، دار الفكر، بيروت.

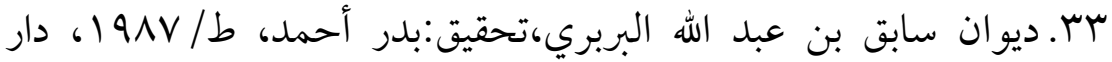

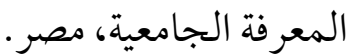
ع ז. روح المعاني في تفسير القرآن العظيم والسبع المثاني، للعلّمة شهاب الدين محمود الألوسي البغدادي، بتحقيق: السيد محمد السيد، وسيد إبراهيم

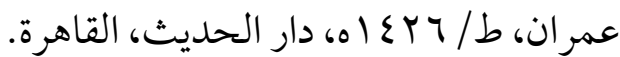
هr. الز اهر في معاني كلمات الناس لأبي بكر ابن الأنباري ، تحقيق حاتم صالح

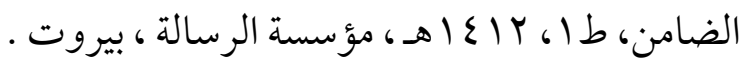

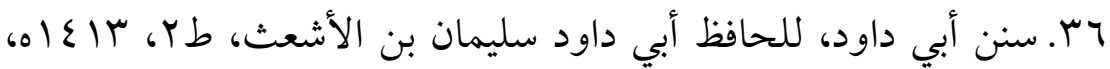
نشر: دار الدعوة ودار سحنون، استطنبول.

$$
\text { سيبويه = الكتاب لسيبويه }
$$

rV محمد محي الدين عبد الحميد ، ط7، دار الفكر ، بيروت. ^r. شرح أشعار الهذليين، لأبي سعيد السكري، تحقيق عبد الستار أحمد، ومحمود شاكر، مطبعة المدني، القاهرة.

هr. شرح الأشموني على ألفية ابن مالك، ط دار إحياء الكتب العربية ،

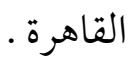

$$
\text { شرح السير افي على سيبويه = شرح كتاب سيبويه }
$$

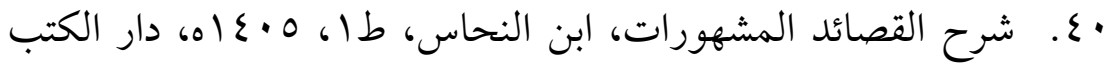
العلمية، بيروت. 


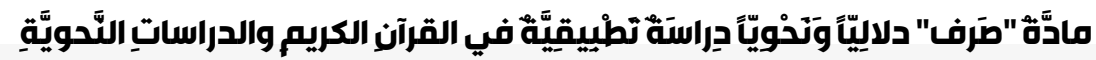

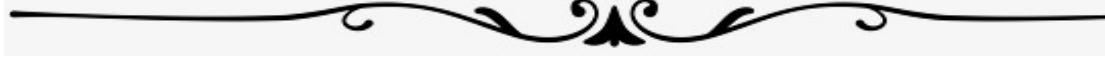

اع. شرح الكافية الشافية لابن مالك، تحقيق عبد المنعم هريدي، ط/ جامعة أم القرى'، دار المأمون للتراث.

rع. شرح اللمع للأصفهاني ، تحقيق إبراهيم أبو عباة ، ط ( ، 1 ( اهـ جامعة

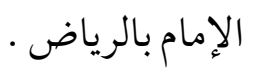

بـع. شرح الملوكي في التصريف لابن يعيش ، تحقيق فخر الدين قباوة ،

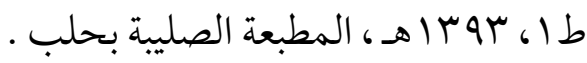

ع ع. شرح شافية ابن الحاجب لرضي الدين الإستر آبادي ، تحقيق محمد نور

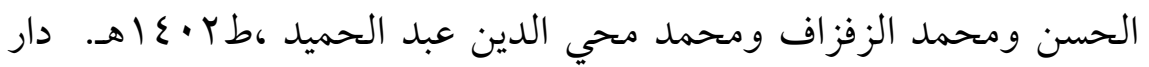

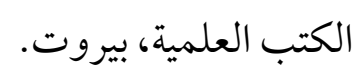

هـ. شرح كتاب سيبويه، لأبي سعيد السيرافي، بتحقيق أحمد مهدلي،وعلي يُورتي

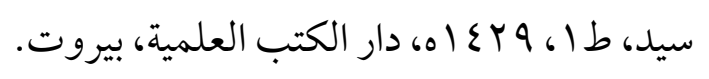

جع. شرح مختصر التصريف العزي في فن الصرف للتفتازاني ، تحقيق عبد

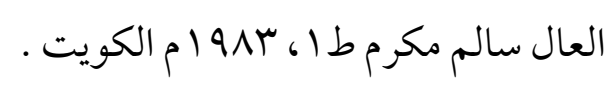

\&V

$$
\text { الشويمي ، بيروت ساحت } 197 .
$$

^乏. الصحاح ، تاج اللغة وصحاح العربية ، لإسماعيل الجوهري ، تحقيق

$$
\text { أحمد عبد الغفور عطار، طس، ع • ع أهـ دار العلم للملايين ، بيروت . }
$$

9. . صحيح البخاري (الجامع المسند الصحيح المختصر من أمور رسول

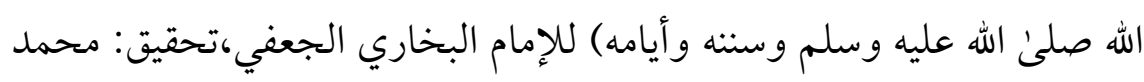

$$
\text { زهير بن ناصر الناصر، ط ا، ب ع ع ا هـ، دار طوق النجاة. }
$$




\section{مجلة كلية اللغة العربية بالمنوفية العدد الخامس والثلاثون - إصدار ديسمبر 2020م}

01. صحيح مسلم (المسند الصحيح المختصر بنقل العدل عن العدل إلى

رسول الله صلى الله عليه وسلم) ، للإمام مسلم النيسابوري،تحقيق: محمد فؤاد

$$
\text { عبد الباقي، دار إحياء التراث العربي - بيروت }
$$

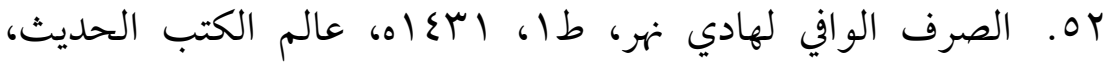

$$
\text { الأردن. }
$$

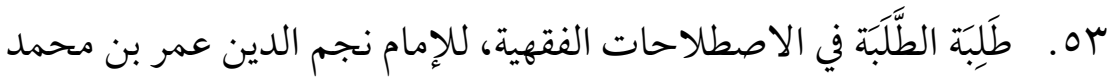

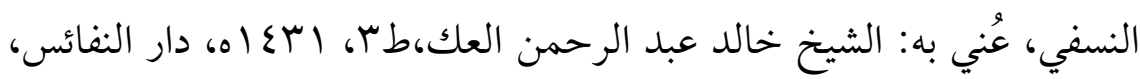

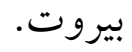

\&. عل علل النحو، لأبي الحسن الوراق، تحقيق مجمود الدرويش،

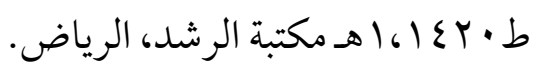

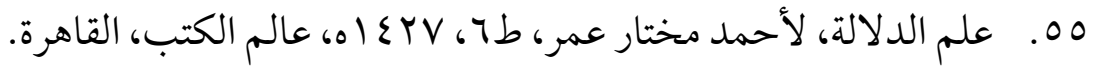
07. العين، للخليل بن أحمد الفراهيدي،تحقيق مهدي المخزومي وإبراهيم

$$
\text { السمرائي، مكتبة الهلال }
$$

oV ه. . غريب الحديث لأبي عبيد القاسم بن سلام الهروي، ط ا، 7 · ع الهـ دار

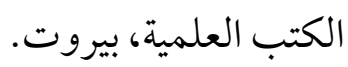

هو. غريب الحديث للخطابي، للإمام أبي سليمان حمد بن محمد الخطابي

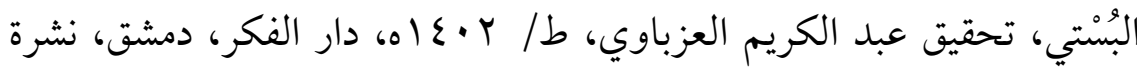
جامعة أم القرى بمكة المكرمة.

•7. الفائق في غريب الحديث، للزمخشري، تحقيق علي البجاوي، ومحمد أبو الفضل، ط ז، عيسى البابي الحلبي وشركاه. 


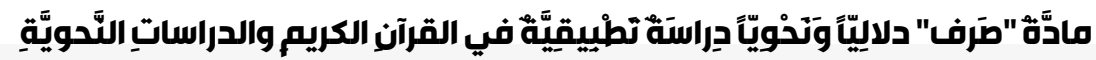

\section{OSC}

آ7. الفائق في غريب الحديث،للزمخشري،تحقيق:علي البجاوي ومحمد

$$
\text { أبو الفضل،ط ب،عيسن البابي الحلبي،مصر. }
$$

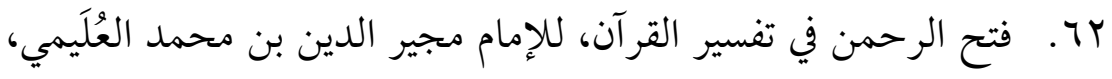

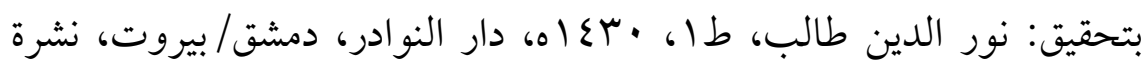
وزارة الأوقاف بدولة قطر.

با7. فصول في الدلالة ما بين المعجم والنحو، للأزهر الزناد، طال، إبع اهـ

$$
\text { تونس. }
$$

ع7. الكامل للمبرد ، تحقيق محمد أحمد الدالي ، طا ، 7 ·ع اهـ مؤسسة

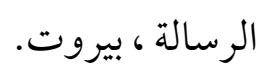

70. كتاب الأفعال، لابن القاطاع الصقلي، تحقيق إبراهيم شمس الدين،

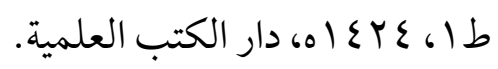

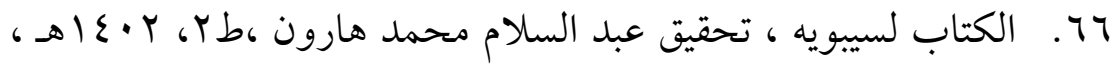

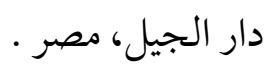

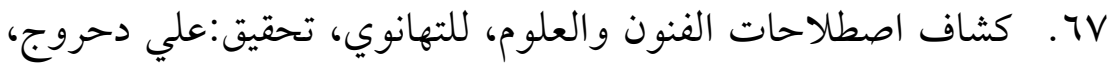

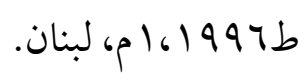

$$
\text { 1 ج. الكشاف للزمخشري، ط/ دار المعرفة -بيروت. }
$$

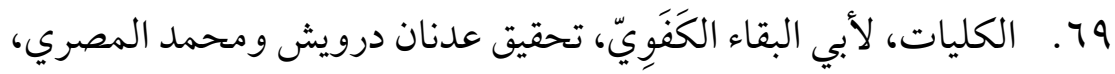

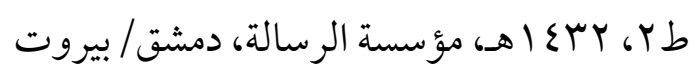

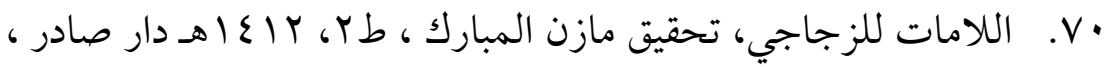

$$
\text { بيروت. }
$$

ال البرو. الباب في علل البناء والإعراب لأبي البقاء العكبري ، تحقيق عبد الآله

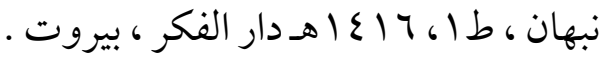


VY. ل لسان العرب لابن منظور الأنصاري، ط دار صادر ، بيروت .

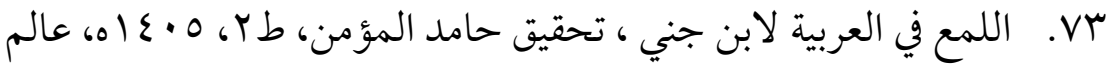
الكتب، بيروت.

ع V. ما لا ينصرف، للزجاج ، تحقيق هدى محمود ، ط ب، ع اع أهـ ، مكتبة

$$
\text { الخانجي ـ القاهرة }
$$

Vo. المجموع المغيث في غريبي القرآن والحديث، للحافظ أبي موسى

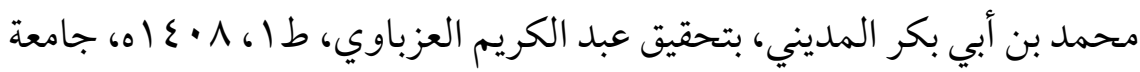

$$
\text { أم القرىن، مكة المكرمة. }
$$

V7. المحرر الوجيز في تفسير الكتاب العزيز للإمام عبد الحق بن عطية

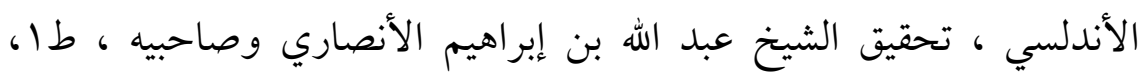

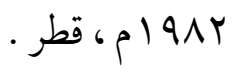

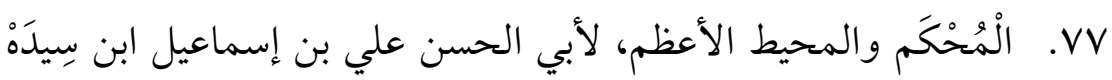

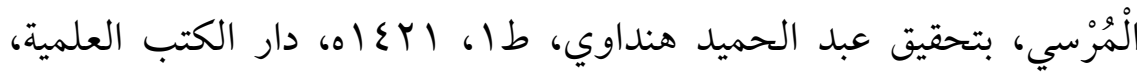

$$
\text { بيروت. }
$$

VA. مدهل إلى علم الدلالة لفرانك بالمر، ترجمة خالد محمود جمعة،ط 1،

$$
\text { 199V }
$$

99. المدخل إلى علم اللغة ومناهج البحث اللغوي لرمضان عبد التواب ،

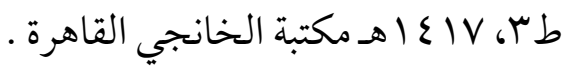

•1. مراقي السعود إلى مراقي السعود، لمحمد الأمين الجكني، تحقيق: محمد المختار الشنقيطي، ط ا ، سا ع (ه، مكتبة ابن تيمية، القاهرة.

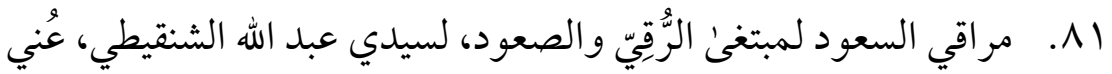
به: محمد ولد سيدي، ط ا، 7 ( \& الم، دار المنارة، جدة. 


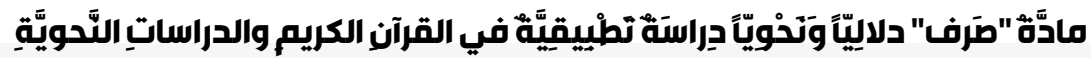

r. r. المزهر في علوم اللغة وأنواعها للسيوطي ، بعناية محمد أحمد جاد

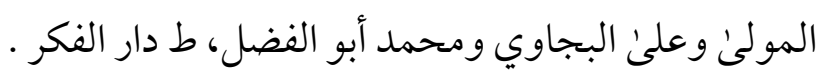

ץ.

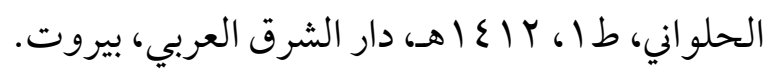

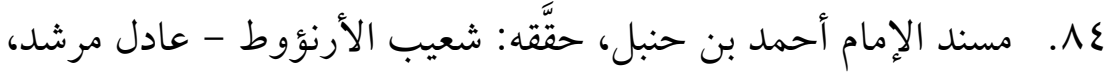
و آخرون، بإشر اف: د. عبد الله التركي، ط ا، ال إع الهـ، مؤسسة الرسالة.

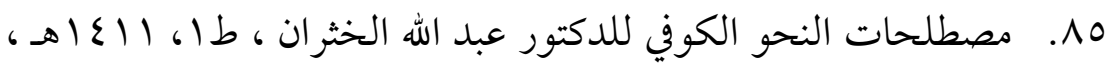
هجر ، مصر

1 1. المطول في شرح تلخيص مفتاح العلوم، لسعد الدين التفتازاني، تحقيق

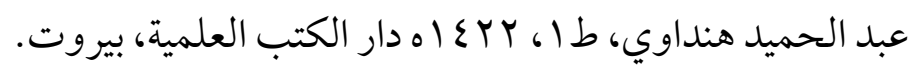
AV

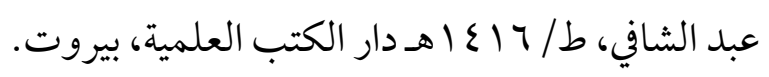

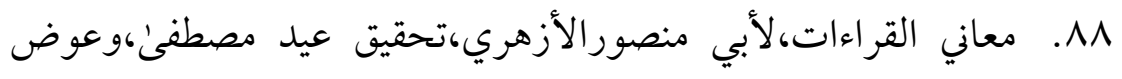

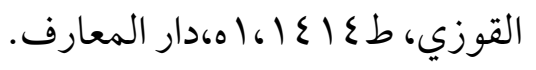

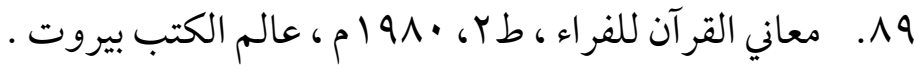
•9. معاني القرآن وإعرابه للزجاج، تحقيق عبد الجليل شلبي، طا،

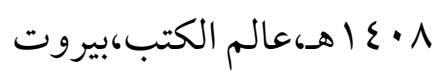

91. معجم أمهات الأفعال معانيها وأوجه استعمالها، لأحمد عبد الوهاب

$$
\text { بكير، ط ا، 19971 19 دار الغرب الإسلامي، بيروت. }
$$

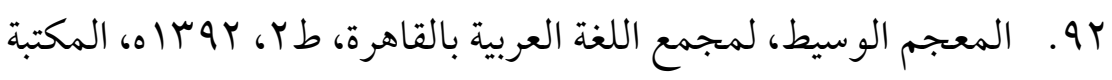
الإسلامية، تركيا. 
rو. المغني لابن هشام: المغني عن كتب الأعاريب، تحقيق مازن المبارك

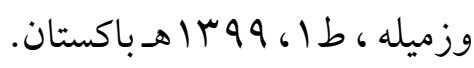

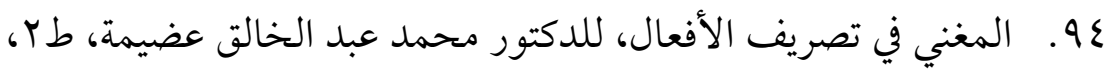

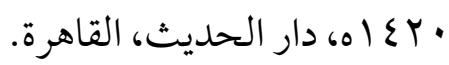

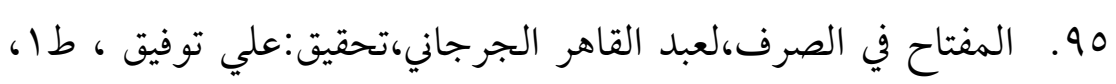

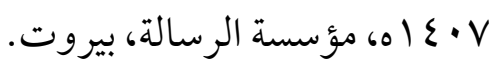

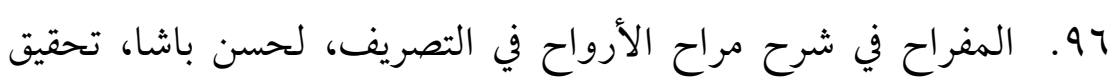

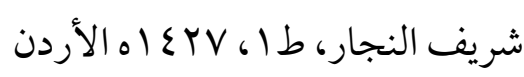

9V

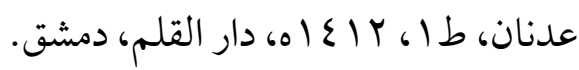

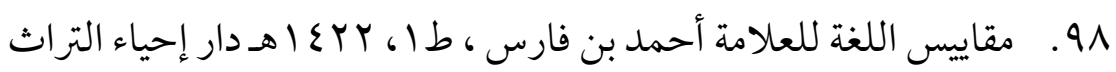

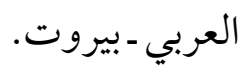

99. المقتضب لأبي العباس المبرد ، تحقيق عبد الخالق عضيمة، ط1، اه

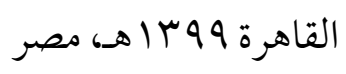

ط . . . الممتع في التصريف لابن عصفور الإشبيلي ، تحقيق فخر الدين قباوة ،

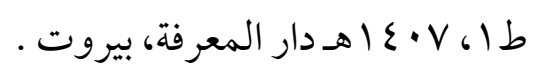

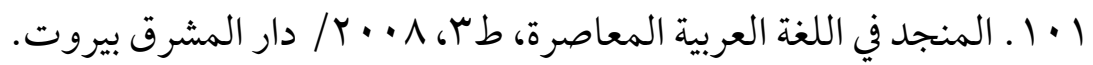

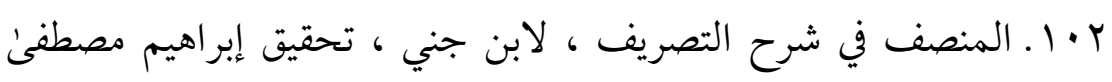

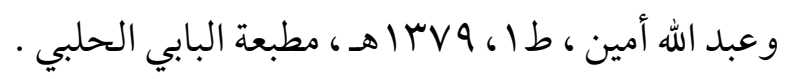

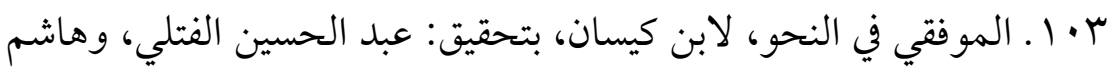

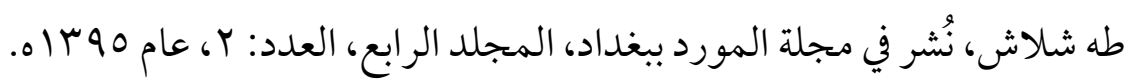




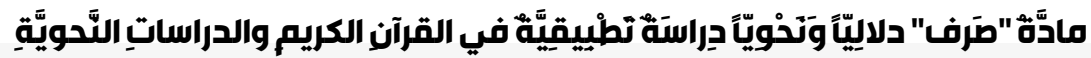

ع • ا ـ نتائج الفكر في النحو، لأبي القاسم السهيلي، حققه: عادل أحمد، وعلي

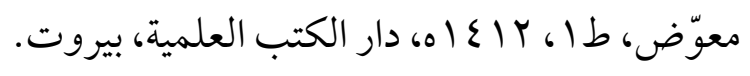

ه • 1 ـ النحو الو افي، لعباس حسن، طه إ، دار المعارف.

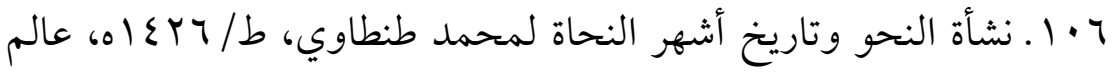

$$
\text { الكتب، بيروت. }
$$

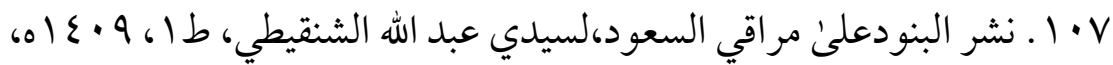

$$
\text { دار الكتب العلمية، بيروت. }
$$

^• • ـ نظرية علم الدلالة، لراث كيمبسون، ترجمة عبد القادر قنيني، طا ل،

$$
\text { • بـ إه، دار الأمان، الرباط. }
$$

9 1 ـ النهاية في غريب الحديث والأثر، للمبارك بن الأثير، تحقيق أحمد

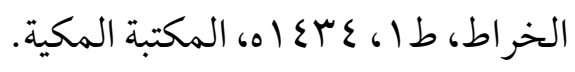

• 11 ـ الوجوه والنظائر لألفاظ كتاب الله العزيز، للحسين بن محمد الدامغاني،

تحقيق: محمد حسن أبو العزم الزفيتي، ط/ بrع (ه، لجنة إحياء التراث بوزارة

$$
\text { الأوقاف المصرية، القاهرة. }
$$

111 الوجيز في علم التصريف، لأبي البركات الأنباري، تحقيق: علي

$$
\text { البواب،ط (ا، ب • ع (اهـ، دار العلوم ، السعودية. }
$$

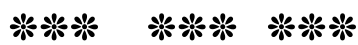

